\author{
UNIVERSIDADE DE SÃO PAULO \\ ESCOLA DE ENFERMAGEM DE RIBEIRÃO PRETO
}

\title{
MICHELLY RODRIGUES ESTEVES
}

Um olhar sobre a rede social no enfrentamento da violência escolar nas instituições de ensino médio de Alfenas-MG

Ribeirão Preto 


\section{MICHELLY RODRIGUES ESTEVES}

\section{Um olhar sobre a rede social no enfrentamento da violência escolar nas}

instituições de ensino médio de Alfenas-MG

Dissertação apresentada à Escola de Enfermagem de Ribeirão Preto da Universidade de São Paulo para a obtenção do título de Mestre em Ciências, Programa Saúde Pública.

Linha de Pesquisa: Assistência à Criança e ao Adolescente

Orientadora: Prof ${ }^{\mathrm{a}}$. Dr ${ }^{\mathrm{a}}$. Maria das Graças Bomfim de Carvalho

Ribeirão Preto 


\section{FICHA CATALOGRÁFICA}

Autorizo a reprodução e a divulgação total ou parcial deste trabalho, por qualquer meio convencional ou eletrônico, para fins de estudo e pesquisa, desde que citada a fonte.

Esteves, Michelly Rodrigues

Um olhar sobre a rede social no enfrentamento da violência escolar nas instituições de ensino médio de Alfenas-MG. Ribeirão Preto, 2012.

88 p. : il. ; $30 \mathrm{~cm}$

Dissertação de Mestrado, apresentada à Escola de Enfermagem de Ribeirão Preto/USP. Área de concentração: Enfermagem em Saúde Pública.

Orientador: Carvalho, Maria das Graças Bomfim de.

1. Redes sociais. 2. Violência. 3. Escolas. 
ESTEVES, M. R.

Um olhar sobre a rede social no enfrentamento da violência escolar nas instituições de ensino médio de Alfenas-MG.

Dissertação apresentada à Escola de Enfermagem de Ribeirão Preto da Universidade de São Paulo para a obtenção do título de Mestre em Ciências, Programa Saúde Pública.

Aprovado em:

Banca Examinadora

Prof. Dr. Instituição:

Julgamento: Assinatura:

Prof. Dr. Instituição:

Julgamento: Assinatura:

Prof. Dr. Instituição:

Julgamento: Assinatura: 


\section{DEDICATÓRIA}

Cansei-me de tanto silêncio. Concedam-me paz, por favor!

Não quero mais sufocar minha alegria e demonstrar a minha dor. Não quero mais viver de melancolia, enquanto poderia distribuir amor. Não quero mais que crianças percam a vida e adultos esqueçam como é o perfume da flor. Não quero mais que o dia perca o sentido e a noite perca o valor. Não quero mais que os sonhos se tornem distantes e que o medo seja sempre constante. Não quero mais que o sorriso se apague com o tempo e que a solidariedade desapareça com a mesma agilidade do vento.

Eu quero um pouco mais de verdade.

Eu quero mais sinceridade.

Eu quero um amanhã diferente. Eu quero um amanhã mais indulgente.

Cansei-me de tanto silêncio. Concedam-me paz, por favor!

Escrevi essa poesia aos 14 anos, sem imaginar que futuramente me empenharia nos estudos sobre violência. Dedico este trabalho a todos que, assim como eu, acreditam na união como estímulo capaz de transformar nossa realidade e de promover a paz. 


\section{AGRADECIMENTOS}

A Deus, presença constante em minha vida. Muitos foram os momentos de cansaço e de incertezas, contudo, Ele me sustentou, guiou meus passos e permitiu mais esta conquista. "Posso, tudo posso, Naquele que me fortalece”. Obrigada, Senhor.

À Profa. Dra. Maria das Graças Bomfim de Carvalho, por ter me acolhido como sua "netinha". Sempre disposta a ouvir, transmitiu-me seus conhecimentos com carinho, com respeito e com humildade.

À Fundação de Amparo à Pesquisa do Estado de São Paulo (FAPESP), pela concessão da bolsa, a qual permitiu que minha qualificação profissional fosse possível.

À minha mãe Maria José Rodrigues Esteves, que esteve ao meu lado em toda a minha caminhada, com ensinamentos de força e de sabedoria, compreendendo minhas ausências. Emociona-me lembrar a história de vida que construímos juntas. Essa vitória também pertence a ela.

Ao meu pai Amauri José Esteves. Tenho certeza de que orou por mim diariamente, sentindo-se realizado a cada etapa que supero.

Ao meu namorado Marcos Vinícius Nascimento Junqueira, por me acompanhar nessa trajetória, com paciência, palavras de ânimo e amor. Certamente, deixa sua contribuição neste trabalho e compartilha comigo este momento de felicidade.

Aos meus familiares, por acreditarem em mim, oferecendo todo o apoio, mesmo quando estavam longe. Recordo especialmente minha avó Carmelita Maria de Jesus, pelas orações redobradas em cada uma das minhas viagens.

Aos meus amigos, por mais que a distância tenha sido inevitável, sei o quanto torceram por mim.

À Hermelinda Penha Freire Maciel, mais que amiga, que conhece minha história há anos, valorizando as escolhas que faço e os bons resultados alcançados.

Às colegas Christianne Alves Pereira Calheiros, Edilaine Assunção Caetano, Fernanda Maria Vieira Pereira e Simone Mara de Araújo Ferreira, por terem facilitado, em diversas ocasiões, as minhas idas para Ribeirão Preto e os esperados retornos para Alfenas por meio de inesquecíveis caronas.

À Luana Rosas Zulian e à Thaís Angelina Caetano, minhas eternas vizinhas Ribeirão-Pretanas. Suas presenças amenizaram a saudade de casa. Tornaram-se amigas, das quais sempre me lembrarei.

Aos colegas da Graduação e Pós-Graduação da Escola de Enfermagem de Ribeirão Preto, que tive a oportunidade de conhecer e conviver. Lembro Patrícia Santos Prudêncio, por me receber em sua casa quando necessitei.

Ao corpo docente da Escola de Enfermagem de Ribeirão Preto, por contribuir com meu desenvolvimento.

Aos funcionários e colaboradores da Escola de Enfermagem de Ribeirão Preto, os quais buscaram atender minhas necessidades da melhor forma possível. Destaque para Shirley Ferreira de Figueiredo e Simone dos Santos Ozanik Registro.

Aos membros do Núcleo de Estudos, Ensino e Pesquisa do Programa de Assistência Primária de Saúde Escolar (PROASE), suas vivências engrandeceram o meu caminhar pelo Mestrado. preparação.

À Prof ${ }^{a}$. Dr ${ }^{a}$. Marta Angélica Iossi Silva, a qual participou dos diferentes momentos de minha

À Prof ${ }^{a}$. Dr ${ }^{a}$. Lygia Maria Pereira da Silva, por partilhar comigo suas experiências.

À Superintendência Regional de Ensino de Varginha, aos diretores das instituições estudadas, bem como aos sujeitos da pesquisa, por terem autorizado e tornado possível a realização deste estudo. 
“Toda a educação é reprodutora, mas ao mesmo tempo, nenhuma sociedade atual seria, sem a escola, o mesmo que chegou a ser com ela, e por isso toda educação é transformadora." 


\section{RESUMO}

ESTEVES, M. R. Um olhar sobre a rede social no enfrentamento da violência escolar nas instituições de ensino médio de Alfenas-MG. 2012. 88f. Dissertação (Mestrado) - Escola de Enfermagem de Ribeirão Preto, Universidade de São Paulo, Ribeirão Preto, 2012.

A violência é um fenômeno sócio-histórico que acompanha a trajetória da humanidade, possui diferentes tipos e geralmente é identificada com dificuldade. Suas manifestações são inúmeras e atingem todos os domínios da vida social. Nesse aspecto, observamos a crescente preocupação com a violência escolar. A interação entre escola, família e comunidade, assim como a possibilidade de se estabelecer uma rede social, constitui-se em um fator relevante para a proteção e o desenvolvimento das habilidades sociais na infância e adolescência bem como para a efetiva atenção à violência no contexto escolar. Este estudo teve como objetivo identificar e analisar as redes sociais em torno das escolas de ensino médio pertencentes à rede estadual de Alfenas-MG para o enfrentamento dos casos de violência escolar. Trata-se de uma pesquisa descritiva, exploratória, de abordagem qualitativa. O campo de estudo foi composto por seis escolas urbanas públicas de ensino médio do município de Alfenas-MG e os sujeitos, nove supervisores pedagógicos das referidas escolas. Os instrumentos de coleta de dados foram o Mapa Mínimo da Rede Social Institucional e a entrevista semiestruturada. A análise dos dados ocorreu apoiada no referencial de Análise de Conteúdo, modalidade Temática, identificando os seguintes Núcleos Temáticos: A Escola e a Violência; Enfrentamento da Violência Escolar. O segundo Núcleo Temático teve como subtemas: Ações Internas e A Atuação em Rede. O fenômeno violência é compreendido com dificuldade e vários atos não são percebidos como violentos. As escolas aplicam advertência verbal ou escrita, comunicam pais ou responsáveis e entram em contato com Conselho Tutelar, Guarda Municipal e Promotoria Pública. No que se refere à atuação em rede, Conselho Tutelar, Promotoria Pública, Guarda Municipal, Prefeitura Municipal e universidades surgiram como apoio para o enfrentamento da violência escolar. Constatamos um número reduzido de vínculos e a fragilidade significativa entre aqueles existentes. Observamos a necessidade de estratégias voltadas à orientação de alunos, funcionários, famílias e comunidade para o enfrentamento das violências que ocorrem no âmbito escolar, sendo preciso o fortalecimento das redes sociais.

Palavras-chave: Redes sociais. Violência. Escolas. 


\begin{abstract}
ESTEVES, M. R. A look at the social network in the fight against school violence in high schools in Alfenas-MG. 2012. 88p. Thesis (MSc) - Ribeirão Preto Nursing School, University of São Paulo, Ribeirão Preto, 2012.

Violence is a social-historical phenomenon that accompanies the history of mankind, has different types and is generally difficulty to be identified. Its manifestations are numerous and affect all areas of life. In this regard, can be noted the growing concern on school violence. The interaction among school, family and community as well as the possibility of establishing a social network, constitutes a relevant factor in the protection and development of social skills in childhood and adolescence as well as for effective attention to violence in the school context. This study was aimed to identify and analyze social networks around the state high schools in Alfenas-MG in the dealing against cases of school violence. It is a descriptive research, exploratory, with qualitative approach. The field study consisted of six urban public schools in Alfenas-MG and the subjects were nine educational supervisors of those schools. The instruments for data collection were the Minimun Map of the Institutional Social Network and the semi-structured interview. The data analysis was supported in the frame of Content Analysis, Thematic modality, identifying the following Core Themes: The School and The Violence; Fight Against School Violence. The second Core Theme was divided in sub-themes: Internal Actions and Acting in Network. The phenomenon of violence is understood with difficulty and some actions are not perceived as violent. The schools conduct verbal or written warning, communicate the parents or guardians, come in contact with Child Protection Council, the Municipal Guard and the Public Prosecutor. Regarding the action in network, Child Protection Council, Public Prosecutor, Municipal Guard, City Hall and universities have emerged as support for the fight against school violence. Were found a small number of links and the significant weaknesses between those existing. It could be seen the need of strategies for orientation of students, staff, families and communities to confront the violence occurring in schools, requiring the strengthening of social networks.
\end{abstract}

Keywords: Social networks. Violence. Schools. 


\section{RESUMEN}

ESTEVES, M. R. Una mirada sobre la red social en el enfrentamiento de la violencia escolar en las instituciones de enseñanza secundaria de la ciudad de Alfenas (Minas Gerais). 2012. 88h. Disertación (Máster) - Escuela de Enfermería de Ribeirão Preto, Universidad de São Paulo, Ribeirão Preto, 2012.

La violencia es un fenómeno socio-histórico que acompaña la trayectoria de la humanidad, posee diferentes tipos y generalmente es identificada con dificultad. Sus manifestaciones son incontables y alcanzan todos los dominios de la vida social. En ese aspecto, observamos la creciente preocupación con la violencia escolar. La interacción entre escuela, familia y comunidad, así como la posibilidad de establecerse una red social, se constituye en un factor relevante para la protección y el desarrollo de las habilidades sociales en la infancia y adolescencia así como para la efectiva atención a la violencia en el contexto escolar. Este estudio tuvo como objetivo identificar y analizar las redes sociales en torno a las escuelas de enseñanza secundaria pertenecientes a la red pública provincial de la ciudad de Alfenas (Minas Gerais) para el enfrentamiento de los casos de violencia escolar. Se trata de una investigación descriptiva, exploratoria, de abordaje cualitativo. El campo de estudio fue compuesto por seis escuelas urbanas públicas de enseñanza secundaria del municipio de Alfenas y los sujetos, nueve supervisores pedagógicos de las referidas escuelas. Los instrumentos de recolección de datos fueron el Mapa Mínimo de la Red Social Institucional y la entrevista semiestruturada. El análisis de los datos se estableció apoyado en el referencial de Análisis de Contenido, modalidad Temática, identificando los siguientes Núcleos Temáticos: La Escuela y la Violencia; Enfrentamiento de la Violencia Escolar. El segundo Núcleo Temático tuvo como subtemas: Acciones Internas y La Actuación en Red. El fenómeno violencia es comprendido con dificultad y varios actos no son percibidos como violentos. Las escuelas aplican advertencia verbal o escritura, comunican a padres o responsables y entran en contacto con el Consejo Tutelar, Guardia Municipal y Fiscalía Pública. En lo que se refiere a la actuación en red, Consejo Tutelar, Fiscalía Pública, Guardia Municipal, Municipalidad y universidades surgieron como apoyo para el enfrentamiento de la violencia escolar. Constatamos un número reducido de vínculos y la fragilidad significativa entre aquellos existentes. Observamos la necesidad de estrategias direccionadas a la orientación de alumnos, trabajadores, familias y comunidad para el enfrentamiento de las violencias que ocurren en el ámbito escolar, siendo necesario el fortalecimiento de las redes sociales.

Palabras clave: Redes sociales. Violencia. Escuelas. 


\section{LISTA DE ABREVIATURAS E SIGLAS}

COHAB Companhia de Habitação Popular

ECA Estatuto da Criança e do Adolescente

EERP Escola de Enfermagem de Ribeirão Preto

ENSP Escola Nacional de Saúde Pública

EJA Educação de Jovens e Adultos

ESFs Equipes de Saúde da Família

FETA Fundação de Ensino e Tecnologia de Alfenas

FIOCRUZ Fundação Oswaldo Cruz

GAPEFAM Grupo de Assistência, Pesquisa e Educação na Área da Saúde e da Família

IBGE Instituto Brasileiro de Geografia e Estatística

LACRI Laboratório de Estudos da Criança

LDB Lei de Diretrizes e Bases da Educação Nacional

MBA Master Business Administration

OMS Organização Mundial da Saúde

ONGs Organizações Não Governamentais

ONU Organização das Nações Unidas

OPAS Organização Pan-americana da Saúde

PAIR Programa de Ações Integradas e Referenciais de Enfrentamento à Violência Sexual Infanto-Juvenil

PCN Parâmetros Curriculares Nacionais

PET Programa de Educação Tutorial

PLHIS Plano Local de Habitação de Interesse Social

PeNSE Pesquisa Nacional de Saúde do Escolar

SUS S Sistema Único de Saúde

UFRGS Universidade Federal do Rio Grande do Sul 
UFRJ

Universidade Federal do Rio de Janeiro

UFSC

Universidade Federal de Santa Catarina

UNIFAL-MG Universidade Federal de Alfenas

UNIFENAS Universidade José do Rosário Vellano

UNIP Universidade Paulista

UNOPAR Universidade Norte do Paraná

USP Universidade de São Paulo

VIVA Vigilância de Violências e Acidentes

WHO World Health Organization 


\section{LISTA DE FIGURAS}

Figura 1 Mapa de Alfenas com o posicionamento das escolas estudadas ......................... 30

Figura 2 Logotipo do projeto “Minha Escola - Onde eu faço meu futuro”........................ 32

Figura 3 Logotipo do programa “Cidade Escola”......................................................... 32

Figura 4 Fluxograma dos casos de violência na escola ................................................... 54

Figura 5 Mapa Mínimo da Rede Social Externa da Escola A ..........................................56

Figura 6 Mapa Mínimo da Rede Social Externa da Escola B......................................... 56

Figura 7 Mapa Mínimo da Rede Social Externa da Escola C...........................................57

Figura 8 Mapa Mínimo da Rede Social Externa da Escola D ......................................... 57

Figura 9 Mapa Mínimo da Rede Social Externa da Escola E .......................................... 58

Figura 10 Mapa Mínimo da Rede Social Externa da Escola F .......................................... 58

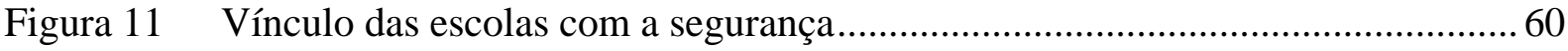

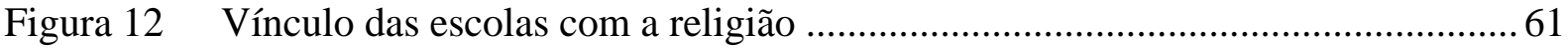

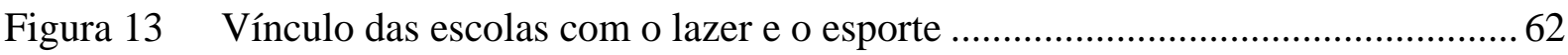

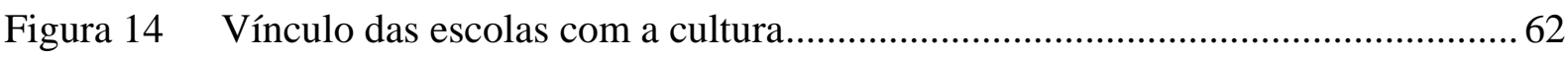

Figura 15 Vínculo das escolas com a assistência social ....................................................65

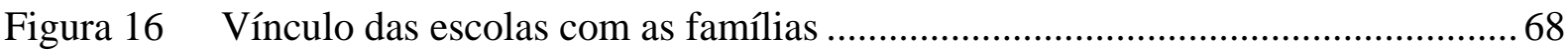

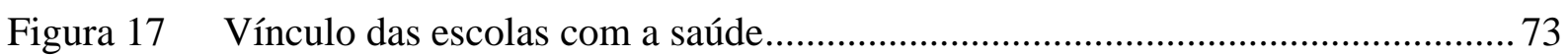

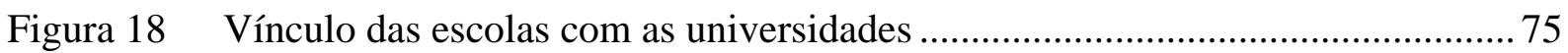

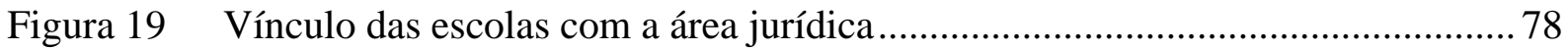




\section{SUMÁRIO}

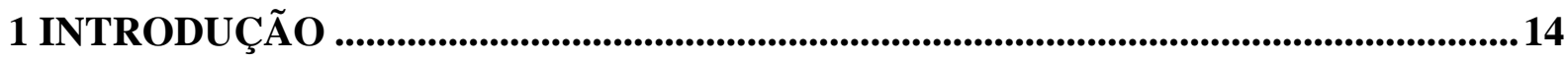

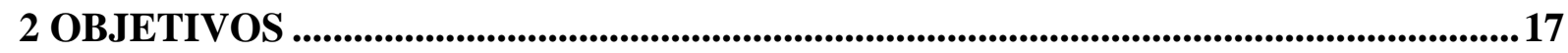

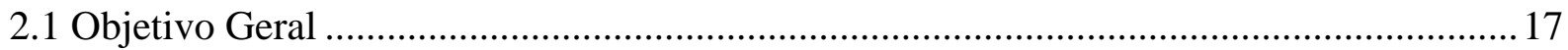

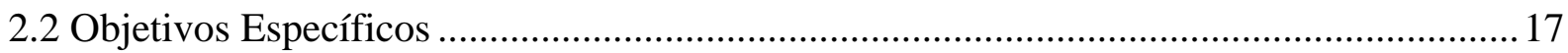

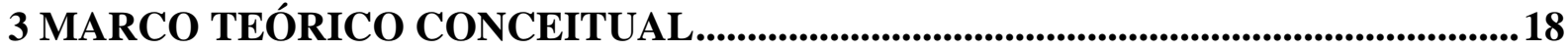

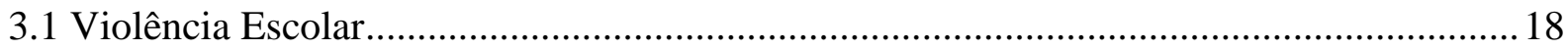

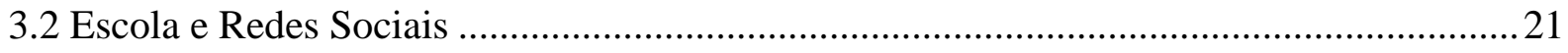

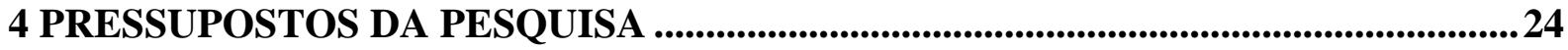

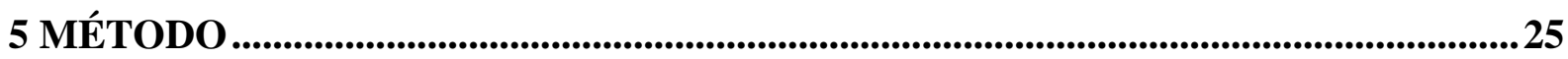

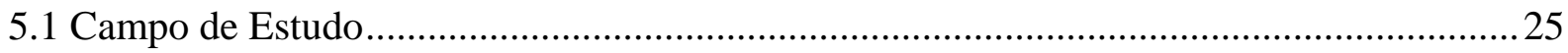

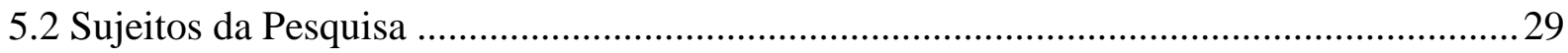

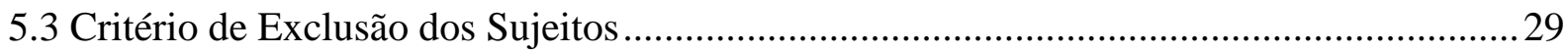

5.4 Instrumento de Coleta e de Análise dos Dados .............................................................. 29

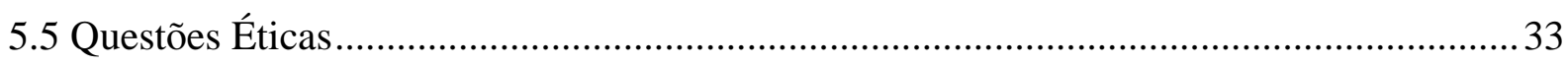

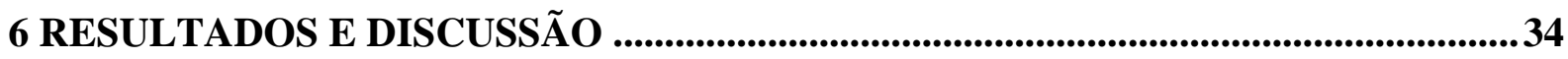

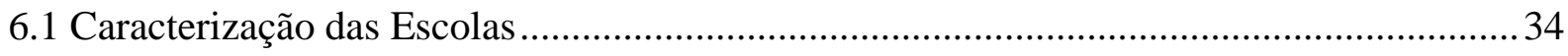

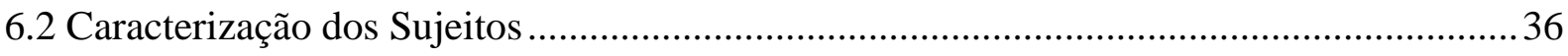

6.3 A Construção dos Núcleos Temáticos ................................................................................ 37

6.3.1 Núcleo Temático: A Escola e a Violência...................................................................... 37

6.3.2 Núcleo Temático: O Enfrentamento da Violência Escolar ............................................ 42

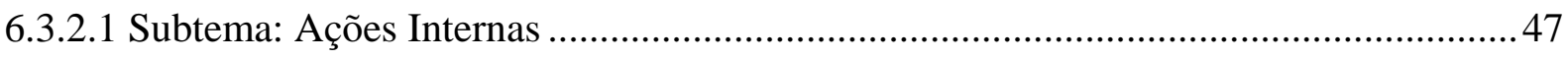

6.3.2.2 Subtema: A Atuação em Rede................................................................................... 50

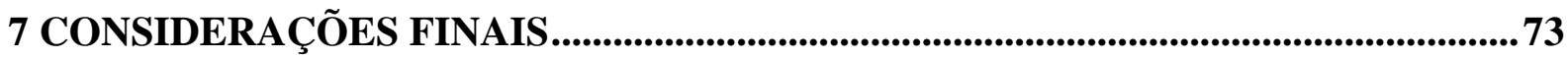

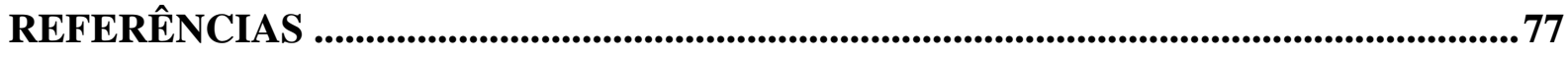

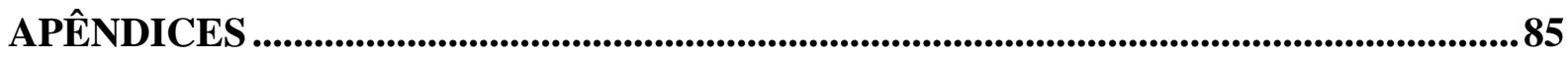

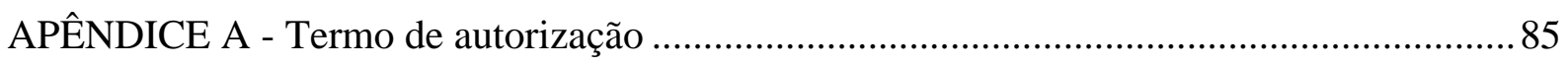

APÊNDICE B - Termo de Consentimento Livre e Esclarecido............................................... 86

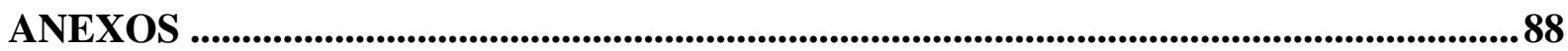

ANEXO A - Mapa Mínimo da Rede Social Institucional ..................................................... 88 


\section{INTRODUÇÃO}

Durante o curso de graduação em Enfermagem na Universidade Federal de Alfenas (UNIFAL-MG), como bolsista do Programa de Educação Tutorial (PET), realizamos um estudo com professores do ensino médio da rede pública de Alfenas, objetivando compreender por meio dos sentimentos e experiências destes educadores o significado da violência na escola. Constatamos que a violência se manifesta nessas instituições, principalmente pelo predomínio de agressões verbais, provenientes de aluno para aluno ou de aluno para professor. Reconhecemos, por meio das falas dos professores, o quanto são importantes para a detecção de problemas existentes no cotidiano dos alunos, contudo apontaram o despreparo para lidar com as situações de violência. Os relatos demonstraram a necessidade de se evitar a violência e reduzir as suas consequências. Todavia, faltam dados no município quanto à violência escolar. Além disso, as medidas adotadas para o enfrentamento da mesma não foram explicitadas nas falas dos sujeitos.

Consideramos importante nos apropriarmos dos diferentes conceitos de violência que têm implicações práticas para a prevenção e manejo do problema que geralmente é identificado com dificuldade (PIRES; MIYAZAKI, 2005).

Segundo a Organização Mundial da Saúde (OMS), World Health Organization (WHO) (2004) as formas de violência são a autoinfligida, que abrange a tentativa de suicídio e abusos autoinfligidos, tais como as mutilações. A coletiva que, envolve grupos contra grupos ou contra indivíduos desses grupos com propósitos políticos, econômicos ou sociais. A interpessoal, que subdivide-se em familiar e conjugal e ocorre entre cônjuges ou entre outros membros da família dentro do lar. A comunitária, que acontece entre pessoas que não apresentam intimidade e se manifesta fora do lar, incluindo a física e a sexual. Aborda-se também a violência institucional, que ocorre em locais de trabalho, em prisões, em escolas, entre outros.

Em 2006, o Ministério da Saúde implantou em vinte e sete municípios brasileiros, no âmbito do Sistema Único de Saúde (SUS), o sistema de Vigilância de Violências e Acidentes (VIVA), a partir da ficha de notificação de violência doméstica, sexual e de outras violências. Os dados coletados mostraram que, na infância e adolescência, a violência física, psicológica, sexual e a negligência são as mais detectadas, sendo a violência sexual a principal causa de atendimento nos serviços de referência de violência (BRASIL, 2008a).

A violência apresenta causas enraizadas no contexto social, cultural e econômico dos indivíduos; fatores biológicos e individuais interagem com fatores familiares e comunitários, 
gerando situações de violência. Contudo, pode ser evitada, e suas consequências, reduzidas, a partir de ações individuais e comunitárias de pequena escala até políticas nacionais, com iniciativas realizadas pelo legislativo (DAHLBERG; KRUG, 2006).

Melman et al. (2009) lembram o Manifesto do ano 2000 da Organização das Nações Unidas (ONU), que foi assinado por milhões de pessoas em todas as partes do planeta, inclusive no Brasil, em que os signatários se comprometeram a seguir em suas vidas seis diretrizes básicas: respeitar a vida, rejeitar a violência, compartilhar os recursos com os outros seres humanos, ouvir para compreender, preservar o planeta e redescobrir a solidariedade.

Os autores apresentam o programa Tecendo Redes de Paz desenvolvido pela Área Técnica de Cultura, de Paz, de Saúde e de Cidadania da Secretaria Municipal de Saúde de São Paulo, responsável pela elaboração das políticas públicas articuladas de prevenção, de promoção da saúde e de atenção integral das pessoas em situação de violência. Citam entre as organizações sociais de caráter público que devem compor as redes locais de enfrentamento à violência: as Delegacias de Polícia, o Conselho Tutelar, o Ministério Público, a Vara da Infância e da Adolescência, os Centros de Cidadania da Mulher, as organizações não governamentais (ONGs) e as comunidades.

Um dos motivos pelos quais a temática da violência merece especial atenção relaciona-se ao fato de a mesma se manifestar em ampla escala nos mais diversos contextos sociais, incluindo as escolas. Segundo Zaluar e Leal (2001), o ambiente escolar apresenta, além da violência física, a violência psicológica, a qual se encontra nos processos de avaliação e nas formas de interação que se estabelecem entre diretores, professores, funcionários, alunos e responsáveis.

Spósito (1998), comentando sobre a produção discente brasileira na Pós-Graduação em Educação, evidenciou que, em um período de 15 anos (1980 - 1995), foram defendidos cerca de 6.092 trabalhos entre teses e dissertações. Desse expressivo volume, apenas quatro estudos (duas teses e duas dissertações) examinaram a violência que atinge a unidade escolar.

Por meio de consulta a Scielo Brasil, utilizando os descritores violência e escola, encontramos um total de 87 artigos no período de 1998 a 2011. Destes, 30 artigos tratam de questões intimamente relacionadas ao nosso estudo, tais como a percepção dos profissionais de educação sobre a violência contra crianças e adolescentes escolares; as múltiplas violências que compõem a violência escolar; o bullying e seus desdobramentos; ações para o enfrentamento da violência escolar, que em sua maioria se dão de modo fragmentado.

A escola possui a função de proteger seus estudantes, crianças e adolescentes contra qualquer violação de seus direitos e de lhes oportunizar condições de pleno desenvolvimento 
escolar, psicológico, sexual, moral e social. Essas responsabilidades não são exclusivas da escola, mas de toda a Rede de Proteção, da qual ela é parte integrante e na qual tem papel preponderante (BRASIL, 2008b).

A instituição escolar compõe a vida social de seus alunos, tendo em vista que ali se estabelecem contatos com o conhecimento e com uma rede de vínculos pessoais e coletivos que podem reconfigurar as maneiras de compreender o mundo. A escola deve estar conectada e articulada a uma rede intersetorial e interorganizacional ampla, constituída por Conselho Tutelar, Delegacia de Polícia, Promotoria Pública, Juizado da Infância e da Juventude, Unidades de Saúde, Núcleo de Atendimento Sociofamiliar, programa Sentinela, o Programa de Ações Integradas e Referenciais de Enfrentamento à Violência Sexual Infanto-Juvenil (PAIR), dentre outros (UDE, 2008).

Diante da relevância de se abordar a violência, da necessidade de ampliar os dados referentes à mesma no âmbito escolar e da dificuldade dos educadores em reconhecerem e trabalharem as questões de violência, deparamo-nos com as seguintes inquietações que motivaram o presente estudo: Como estão estruturadas as redes sociais em torno das escolas públicas de ensino médio de Alfenas-MG? Qual a qualidade dos vínculos estabelecidos com essas escolas? Quais ações têm sido realizadas nos últimos anos para o enfrentamento da violência escolar?

Desse modo, este estudo se justifica pela necessidade de se identificar a estrutura de atendimento dos casos de violência escolar nas instituições de ensino médio pertencentes à rede estadual de Alfenas-MG na visão dos supervisores pedagógicos, tendo em vista que uma rede organizada pode proporcionar uma releitura do papel da escola nos dias atuais. 


\section{OBJETIVOS}

\subsection{Objetivo Geral}

Identificar e analisar as redes sociais em torno das escolas de ensino médio pertencentes à rede estadual de Alfenas-MG para o enfrentamento dos casos de violência escolar.

\subsection{Objetivos Específicos}

- Identificar os vínculos institucionais das escolas públicas de ensino médio do município pesquisado para o enfrentamento da violência escolar;

- Conhecer as ações desenvolvidas pelas instituições relacionadas às escolas para o enfrentamento da violência. 


\section{MARCO TEÓRICO CONCEITUAL}

Tendo em vista o objeto de estudo, bem como a complexidade da violência, buscamos uma fundamentação teórica que nos permitisse uma melhor compreensão desse fenômeno, de sua interação com o âmbito escolar e da rede em torno das escolas.

\subsection{Violência Escolar}

Muitos estudos discutem os efeitos traumáticos da violência, tal como aponta um dos documentos da Organização Pan-americana da Saúde (OPAS) (1994) ao dizer que a violência, pelo número de vítimas e pela magnitude de sequelas orgânicas e emocionais que produz, adquiriu um caráter endêmico. Segundo Minayo (2005), no ano 2000, chegaram aos serviços públicos de saúde brasileiros, 693.961 pessoas buscando tratamento hospitalar para lesões e traumas provenientes de acidentes e de violências. O custo médio de tratamento de uma pessoa ferida, traumatizada ou lesionada por acidentes e violências, foi de $\mathrm{R} \$ 506,52$ (quinhentos e seis reais e cinquenta e dois centavos), bem acima do $\mathrm{R} \$ 403,38$ (quatrocentos e três reais e trinta e oito centavos), que correspondem ao custo médio das internações em geral.

A mesma autora assevera que a violência é um fenômeno sócio-histórico, acompanha a trajetória da humanidade e se transforma em um problema para a saúde pública porque afeta a saúde individual e coletiva, exigindo a formulação de políticas específicas, a organização de práticas e de serviços peculiares ao setor.

Buscando conceituar a violência, Minayo (2005) afirma que a violência é múltipla. De origem latina, o vocábulo vem da palavra vis que quer dizer força e se refere às noções de constrangimento e de uso da superioridade física sobre o outro.

A Política Nacional de Redução da Morbimortalidade por Acidentes e Violências, divulgada pelo Ministério da Saúde do Brasil, considera como violências “as ações realizadas por indivíduos, grupos, classes, nações, que ocasionam danos físicos, emocionais e espirituais a si próprios e aos outros” (BRASIL, 2001).

Instituições nacionais e internacionais têm o consenso de que a violência representa uma ameaça ao desenvolvimento humano. Grandes empenhos têm sido visíveis ao longo dos anos com o propósito de debater a temática, buscando sua conceituação. Para fins deste 
estudo, sempre que nos referirmos à violência, adotaremos o conceito assumido pela WHO (2002) no primeiro Relatório Mundial sobre Violência e Saúde. Segundo a OMS, a violência é entendida como "o uso intencional da força ou poder em uma forma de ameaça ou efetivamente, contra si mesmo, outra pessoa, grupo ou comunidade, que ocasiona ou tem grandes probabilidades de ocasionar lesão, morte, dano psíquico, alterações do desenvolvimento ou privações”.

As manifestações da violência são inúmeras e atingem todos os domínios da vida social. Nesse aspecto, observamos a crescente preocupação com a violência escolar. Segundo Seixas (2005), o interesse pelo estudo no âmbito da violência escolar advém, entre outros fatores, da maior frequência e visibilidade dos casos, associadas à consequente preocupação evidenciada pelos diversos profissionais e/ou intervenientes no contexto educativo.

Para Vale e Costa (1998), o conceito de violência escolar constitui um fenômeno multifacetado, abrangendo uma variedade de manifestações, desde comportamentos antissociais, delinquência, vandalismo, comportamentos de oposição, entre outros.

Sisto (2005) reconhece que, no ambiente escolar, os atos violentos mais comuns são depredações e invasões dos prédios; agressões físicas e verbais envolvendo alunos, professores e funcionários das escolas; rivalidades, ameaças; tudo isso com forte influência do tráfico de drogas (principalmente em periferias), na determinação de espaços de poder e na banalização da violência.

Charlot (2002) distingue os termos violência na escola, violência à escola e violência da escola. Como violência na escola, considera ser aquela que ocorre dentro do espaço escolar, sem estar ligada à natureza e às atividades da instituição escolar. A violência à escola relaciona-se à natureza e às atividades da instituição escolar: quando os alunos batem nos professores ou os insultam, por exemplo. A violência da escola constitui uma violência institucional, simbólica, que os jovens suportam por meio da maneira como a instituição e seus agentes os tratam. $\mathrm{O}$ autor argumenta que essa distinção é importante no sentido de que, se a escola é, em grande medida, impotente com respeito à violência na escola, a qual é reflexo do mundo externo, ela não o é com respeito a sua ação diante da violência da escola e à escola.

Abordaremos o fenômeno como violência escolar, pois concordamos com Priotto e Boneti (2009), que afirmam se tratar de uma denominação mais abrangente, por englobar violência na, da e à escola. Para Priotto (2009), denomina-se violência escolar todos os atos ou ações de violência, comportamentos agressivos e antissociais, incluindo conflitos interpessoais, danos ao patrimônio, atos criminosos, marginalizações, discriminações, dentre outros. 
A violência presente nos cenários escolares sempre existiu, recebendo diferentes denominações e, atualmente, destaca-se pelo fenômeno bullying, o qual atingiu proporções mundiais, não apresentando uma tradução precisa na língua portuguesa. A utilização do termo é recente, mas a sua manifestação é antiga. Conforme Almeida, Lisboa e Caurcel (2007), Pizarro e Jiménez (2007) e Lopes Neto (2005), o bullying escolar ocorre por intermédio da intimidação de um aluno por um ou vários colegas, com a intenção clara de lhe provocar sofrimentos e apresenta caráter repetitivo e intencional. Trata-se das diversas formas de violência tão conhecidas pela sociedade, indo ao encontro de Priotto e Boneti (2009) ao dizerem que atitudes como ofender, ignorar, excluir, ferir, humilhar, sempre foram encontradas nas escolas de ensinos fundamental e médio, tanto públicas como particulares. Segundo esses autores, nos dias atuais, o fenômeno tem ganhado proporções maiores, ultrapassando, muitas vezes, os limites escolares e invadindo a vida pessoal, por meio de mensagens pela internet e por celulares.

A escola contemporânea é vista como uma instituição envolvida pela violência, refletindo tensões e conflitos de grupos do seu entorno, conhecendo a dilaceração de seus processos sociais e tornando-se objeto da mídia, principalmente quando relacionada a crimes, a contravenções e à delinquência juvenil (OLIVEIRA, 2009).

O mesmo autor acrescenta que os comportamentos violentos dentro da escola demonstram relação com a formação de gangues e de grupos de adolescentes que atuam pela intimidação dos mais fracos e tentam liderar o ambiente escolar.

A violência escolar atinge também os professores e, na maioria das vezes, os mesmos não se encontram preparados para o enfrentamento da situação, tornando-os impotentes, o que dificulta o processo ensino-aprendizagem.

Dentre os autores que tentam explicar as causas da violência escolar, Spósito (1998) questiona o binômio pobreza e violência. Assegura que mais do que a pobreza em termos absolutos, seria a exacerbação da desigualdade social, a extremada distribuição desigual da renda ao lado da convivência no mesmo espaço, uma das condições propícias às relações de violência e suas consequências sobre a escola.

Priotto e Boneti (2009) afirmam a violência como um processo que começaria na família, na falta de limites e de referências da maioria dos adolescentes e teria continuidade nos grupos e nas relações sociais pertencentes ao ambiente externo à escola. Também há as causas socioeconômicas, a falta de oportunidades e de trabalho, o tráfico de drogas, a influência da mídia, o tempo livre e ocioso, a falta de perspectivas e de sonhos.

Recordando o papel fundamental da escola, ou seja, o de educar, Eyng et al. (2005) asseveram que, enquanto instituição, a escola é uma entidade social que deve educar, assim 
como tem ou deveria ter em suas bases os valores éticos e morais, suficientes para nortear os comportamentos dos indivíduos dentro de uma sociedade, principalmente aqueles tidos como inadequados.

A violência, enquanto vontade de destruir, de aviltar, de atormentar, causa um problema, principalmente em uma instituição que, como a escola, inscreve-se na ordem da linguagem e da troca simbólica, não na da força física. Isso significa que o problema não é fazer desaparecer da escola a agressividade e o conflito, mas regulá-los pela palavra e não pela violência, ficando bem entendido que a violência será mais provável na medida em que a palavra se tornar impossível (CHARLOT, 2002).

Entendemos que a oposição a todas as formas de violência constitui uma dimensão da função educativa atribuída à escola e que a mesma pode significar o ponto de partida para a articulação de redes sociais que atuem no enfrentamento da violência.

\subsection{Escola e Redes Sociais}

Por meio dos fundamentos teóricos abordados, entendemos a escola como um locus de proteção social e articulador da rede, com o propósito de prevenção e atenção à violência, reconhecendo que estamos nos referindo a um fenômeno complexo.

Trabalharemos o conceito de redes sociais, o qual, muitas vezes, é confundido com apoio social. Para Pedro, Rocha e Nascimento (2008), rede social é uma terminologia utilizada para descrever a ligação e a interação entre instituições tais como família, vizinhança e organizações religiosas. Apoio social refere-se às trocas interpessoais entre os membros da rede, promovendo atenção às necessidades individuais e sociais.

Dessen e Braz (2000) complementam que a rede social constitui um sistema composto por vários indivíduos, funções e situações, que oferece apoio instrumental e emocional à pessoa ou instituição, em suas diferentes necessidades.

As redes sociais definem-se como o compartilhamento de poder, de recursos humanos e de materiais de um conjunto social, formal ou informal, de atores, de grupos e de instituições em um determinado território. São tecidos sociais que se articulam em torno de objetivos e de focos de ação comuns em que as decisões são tomadas e os conflitos resolvidos democraticamente, buscando-se consensos mínimos que garantam ações conjuntas (BRASIL, 2008b). Recentemente, à definição de rede social foi agregado o elemento afetivo, em função 
da importância do afeto para a construção e para a manutenção do apoio. A possibilidade de se desenvolver em um ambiente afetivo protege crianças e adolescentes de doenças, de sintomas psicopatológicos e de sentimentos de desamparo, mesmo diante de situações adversas (HABIGZANG et al., 2006).

A concepção de rede social emergiu na área das ciências humanas e seu conceito tem sido aplicável à saúde. As redes sociais podem ser de natureza primária e/ou secundária. Nas redes primárias, os vínculos estabelecidos são caracterizados pelas relações de parentesco, de amizade ou de vizinhança, e estão fundados sobre a reciprocidade e sobre a confiança. As secundárias podem ser formais ou informais, de terceiro setor, de mercado ou mistas. Diferenciam-se entre si pelo tipo de troca intercambiada: a reciprocidade, o direito, o dinheiro ou uma combinação desses meios (SOUZA; SOUZA; TOCANTINS, 2009).

A rede de proteção de crianças e adolescentes é o conjunto social constituído por atores e por organismos governamentais e não governamentais, articulado e construído com o objetivo de garantir os direitos gerais ou específicos da parcela da população infanto-juvenil. Como exemplos, podemos citar a Rede de Proteção de Adolescentes em Conflito com a Lei, a Rede de Enfrentamento da Violência Sexual contra Crianças e Adolescentes e a Rede de Proteção dos Meninos e Meninas de Rua, dentre outras. Essas redes podem ter abrangência municipal, estadual, nacional ou internacional e têm como marco de referência o Sistema de Garantia de Direitos estabelecido no Estatuto da Criança e do Adolescente (ECA) (BRASIL, 2008b).

O trabalho em redes sociais parte do princípio da incompletude institucional, no qual se compreende que nenhuma instituição consegue resolver todos os problemas de maneira isolada do seu meio. Dentre as funções da rede, destacam-se o fortalecimento e a otimização de ações, o apoio emocional entre os membros, o uso compartilhado de recursos (implicando uma reciprocidade), a orientação informativa e a complementaridade de tarefas (UDE, 2008).

Martins (2008) refere que a discussão sobre redes sociais responde diretamente aos anseios dos setores da sociedade civil, desejosos de promover políticas de inserção e de participação social. Acrescenta que o assunto atinge também intelectuais e técnicos interessados em promover ações de descentralização em áreas estratégicas como saúde e educação, visando a criar condições institucionais favoráveis para a emancipação de experiências de esfera pública e democrática. Nesse sentido, as redes sociais aparecem como recurso decisivo para permitir o avanço de programas territorializados, que exigem envolvimento e participação ativa das populações locais, objetivando a promoção da cidadania e a democratização da vida local. 
Oliveira (2000a) assegura que, por intermédio dos estudos das redes, podemos mapear as relações entre indivíduos ou grupos, iniciando-se pelos contatos diretos, ou estudá-los a partir das variáveis intensidade, tamanho, frequência e qualidade dos contatos. Ao estudar as redes e sua interação com o ambiente escolar, podemos identificar, entre outros aspectos, lacunas, potencialidades e fragilidades com o propósito de fortalecimento, o qual será essencial para a superação de situações adversas, como a violência.

Mendes (2009) assevera que o trabalho em rede possibilita a intervenção sobre a violência nos três níveis de atenção. Na dimensão primária, tentando eliminar e reduzir os fatores de risco; na secundária, lidando com as situações já existentes, na tentativa de impedir novas formas de violência e a repetição das já ocorridas; e no nível terciário, no que se refere ao acompanhamento integral à vítima e ao agressor.

O mesmo autor acredita que a escola apresenta a capacidade de convergir os nós do atendimento e estabelecer parcerias que permitam o desenvolvimento das potencialidades dos estudantes e de seu grupo de convívio.

Ude (2008) afirma que as escolas apresentam potencial para articular os serviços e monitorar o desenvolvimento das ações. Isso não significa que a escola seja a única responsável pelo processo de articulação dos serviços em redes sociais. Todavia, representa uma peça-chave no desenvolvimento dessa proposta, além de poder solicitar ações que permitam a emancipação dos sujeitos. A instituição escolar necessita estar articulada em si, por meio de fóruns, comissões, grupos de trabalho e conselhos para fomentar trabalhos em rede.

Reconhecer a centralidade da escola na formação das novas gerações corresponde ao reconhecimento dos limites que são inerentes a sua esfera de atuação. Isso tem levado à compreensão de que somente por meio do estabelecimento de parcerias voltadas à construção de redes sociais será possível aos educadores enfrentar com êxito o fenômeno da violência (BRASIL, 2004). 


\section{PRESSUPOSTOS DA PESQUISA}

Pressupomos que a violência constitua um fenômeno pouco compreendido pelos profissionais que atuam nas escolas, os quais assumem várias atribuições e responsabilidades nesse aspecto, mas não se sentem preparados para lidar com tais situações.

Outro pressuposto consiste na possibilidade de as redes sociais estabelecidas junto às instituições escolares apresentarem lacunas e fragilidades, dificultando o enfrentamento dos casos de violência detectados. 


\section{MÉTODO}

O método adotado neste trabalho é o estudo descritivo e exploratório, a partir de uma abordagem qualitativa. Trata-se de pesquisa estratégica que, conforme Minayo (1991), fundamenta-se nas teorias das ciências sociais, mas têm como principal objetivo esclarecer determinados aspectos da realidade para a ação das políticas públicas. Seus instrumentos são frequentemente interdisciplinares e seus resultados se encaminham para a solução de problemas.

Para Cervo e Bervian (2002), o estudo descritivo observa, registra, analisa e correlaciona fatos ou fenômenos sem manipulá-los; procura descobrir, com a precisão possível, a frequência com que o fenômeno ocorre, sua correlação e sua conexão com outros, sua natureza e suas características.

A pesquisa descritiva possibilita o desenvolvimento de um nível de análise em que se permite identificar as diferentes formas dos fenômenos, sua ordenação e classificação. É um tipo de estudo que permite ao pesquisador a obtenção de uma melhor compreensão do comportamento de diversos fatores e elementos que influenciam determinados fenômenos (OLIVEIRA, 2000b).

Segundo Gil (2002), a pesquisa exploratória tem como objetivo proporcionar maior familiaridade com o problema, com vistas a torná-lo mais explícito. Pode envolver levantamento bibliográfico e entrevistas com pessoas experientes no problema pesquisado.

\subsection{Campo de Estudo}

Analisamos seis escolas urbanas públicas da rede de ensino médio do município de Alfenas localizado no Sul do Estado de Minas Gerais, que somam aproximadamente 4.000 alunos matriculados, as quais foram denominadas de escolas A, B, C, D, E e F para efeito de maior entendimento, conservando-se o anonimato das mesmas. 


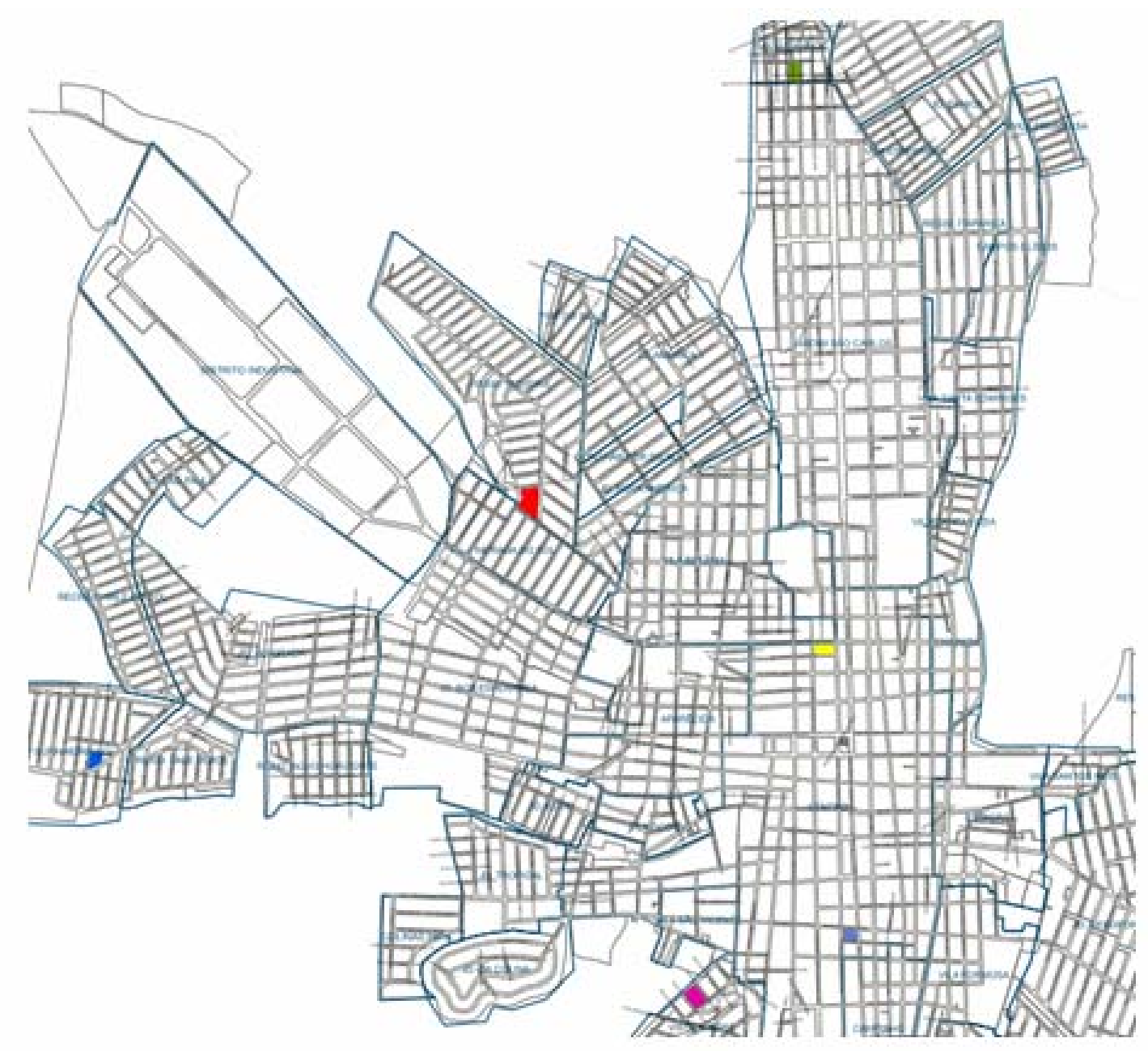

Legenda
EscolaA
Escola B
Escola C
EscolaD
EscolaE
Escola F

Figura 1 - Mapa de Alfenas com o posicionamento das escolas estudadas

Fundada em 15/10/1869, com uma área aproximada de 848,320 km² e uma população de 72.512 habitantes (IBGE, 2010), Alfenas é considerada o núcleo urbano mais importante da região. Segundo a Secretaria de Planejamento, em Alfenas não existe uma lei de zoneamento urbano que permita a delimitação dos bairros, os quais surgiram à medida que se realizaram os loteamentos. Contudo, existe uma proposta a ser enviada ao Legislativo para futura criação de tal lei.

Tradicionalmente, agropastoril e grande centro produtor de café, apresenta o lago artificial de Furnas. A pecuária leiteira é bastante desenvolvida bem como iniciativas na 
agroindústria, principalmente no setor dos gêneros alimentícios, como sucos e laticínios. Possui um Distrito Industrial que é um dos maiores do Sul de Minas.

A cidade é considerada polo de saúde na região, sendo referência para os demais vinte e seis municípios sob jurisdição da Superintendência Regional de Saúde de Alfenas. Conta com três hospitais, um privado e os demais são instituições filantrópicas e atendem de forma pública e privada; 12 Equipes de Saúde da Família (ESFs); duas Unidades de Saúde; dois ambulatórios; um centro odontológico; um Centro de Apoio Psicossocial; oito Residências Terapêuticas; um centro de convivência voltado para a clientela da saúde mental. No que diz respeito aos serviços de saúde contratados e/ou conveniados, existem sete ambulatórios; uma policlínica; um instituto de acupuntura e massoterapia; um instituto de olhos; uma clínica de Psicologia; uma clínica especializada em tratar pacientes com deformidades craniofaciais e com lesões labiopalatais; uma clínica de Fonoaudiologia e uma clínica de Fisioterapia.

Destaca-se a existência de duas universidades, uma pública e outra privada Universidade Federal de Alfenas e Universidade José do Rosário Vellano (UNIFENAS) respectivamente, além dos polos da Universidade Norte do Paraná (UNOPAR) e Universidade Paulista (UNIP).

Quanto aos demais níveis de ensino, os quais abrangem educação infantil, fundamental e médio, são 14 centros de educação infantil, sendo a metade deles municipais; quatro escolas municipais de educação infantil e duas privadas; 12 escolas estaduais; 11 escolas municipais; seis colégios privados.

Com relação às manifestações de violência na escola, a Guarda Municipal realiza a Ronda Escolar, atendendo também aos chamados das escolas. No momento, apenas um Guarda percorre todas as escolas e o mesmo, voluntariamente, realiza um projeto intitulado "Minha Escola - Onde eu faço meu futuro", o qual tem como público alvo os alunos do $1^{\circ}$ ao $5^{\circ}$ ano de quatro escolas estaduais de ensino fundamental. 


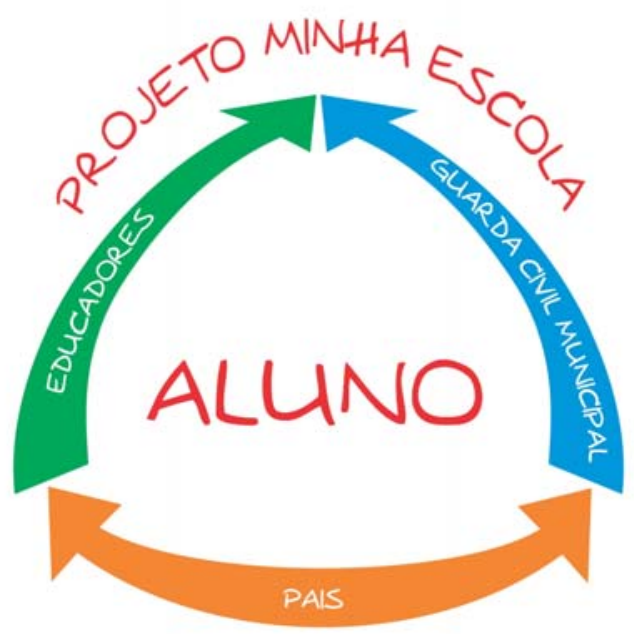

Figura 2 - Logotipo do projeto “Minha Escola - Onde eu faço meu futuro”

Por meio de música, de teatro, de esportes, de passeios e de palestras sobre trânsito e meio ambiente, o projeto tem como objetivos despertar o interesse dos alunos pelos estudos, pela leitura e pela iniciação à música, ao teatro e ao esporte; gerar momentos de reflexão; proporcionar um ambiente de amizade e de respeito entre alunos, educadores, pais e Guardas Municipais.

Ainda voltado para as escolas, no município identificamos o programa "Cidade Escola”, criado pela Secretaria Municipal de Educação e Cultura e realizado junto aos alunos, oferecendo diferentes estímulos, com o propósito de atender todas as escolas estaduais e municipais. As atividades são desenvolvidas no contra-turno do educando, caminhando para a educação em período integral, acompanhadas de projetos de cunho pedagógico, com foco na leitura, na escrita e em cálculos matemáticos.

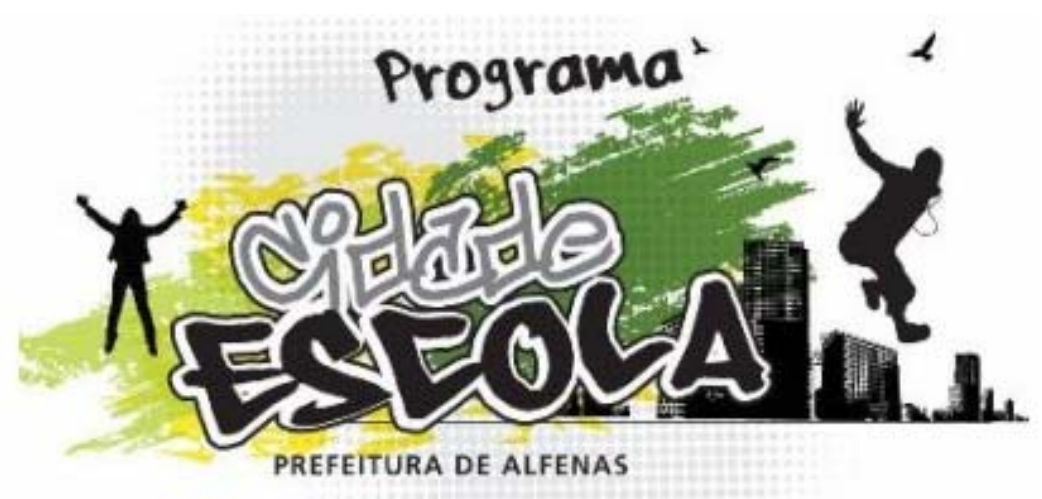

Figura 3 - Logotipo do programa "Cidade Escola” 


\subsection{Sujeitos da Pesquisa}

A cidade de Alfenas apresenta seis escolas estaduais de ensino médio. Dentre seus funcionários, supervisores e orientadores são considerados Especialistas de Educação, desempenhando importante papel na coordenação e articulação do processo ensinoaprendizagem, sendo corresponsáveis com a direção da escola, na liderança da gestão pedagógica que deve ser o eixo a nortear o planejamento, a implementação e o desenvolvimento das ações educacionais. Nesse sentido, abrem-se para o Especialista três campos fundamentais de atuação na escola, interligados e articulados entre si, abrangendo as ações de planejamento, implementação, organização e avaliação do processo de ensinoaprendizagem, mediados pela necessidade de se garantir um clima interno favorável ao desenvolvimento dessas ações e, ainda, a necessária e indispensável participação e envolvimento com os pais e a comunidade (MINAS GERAIS, 2008).

Os cargos de supervisão e de orientação, para serem disponibilizados, dependem do número de alunos matriculados que devem ser 250 alunos e 700 alunos, respectivamente. Desse modo, das seis escolas analisadas, apenas duas apresentavam orientador em um dos turnos de serviço, estando a figura do supervisor presente em todas as seis. Por essa razão, optamos por adotar os supervisores como sujeitos da presente pesquisa.

\subsection{Critério de Exclusão dos Sujeitos}

Dentre os supervisores, optamos por não incluir aqueles que apresentavam um período de exercício do cargo na instituição inferior há um ano, visando ao maior conhecimento da realidade vivenciada pela instituição e seus atores.

\subsection{Instrumento de Coleta e de Análise dos Dados}

A coleta de dados ocorreu no período de fevereiro à março de 2011, nas próprias escolas, atendendo às disponibilidades de horários dos sujeitos. 
Como instrumento de coleta de dados, optamos por utilizar o Mapa Mínimo da Rede Social Institucional (ANEXO A) para mapear os vínculos institucionais das escolas do ensino médio pertencentes à rede estadual de Alfenas-MG que se estabelecem a partir dos casos de violência. Esse Mapa foi elaborado por Walter Ude (2008), tendo como referência o Mapa Mínimo da Rede Pessoal Social criado pelo psiquiatra argentino Carlos Sluzki (1997).

Para a elaboração do Mapa, foi solicitado que os sujeitos auxiliassem a pesquisadora, representando, de forma mais ampla possível, as instituições próximas ou distantes do contexto da escola.

A análise do mesmo foi feita pela pesquisadora acompanhada pelos sujeitos para que fossem alcançadas significações mais profundas. Foram adotadas linhas que indicaram os vínculos significativos, fragilizados, rompidos ou inexistentes. Ao finalizar essa parte, foi iniciada a avaliação do Mapa quanto à quantidade e à qualidade dos vínculos institucionais, à distribuição de instituições em cada quadrante e às características das mesmas.

O Mapa institucional permitiu uma avaliação da rede interna da instituição, ou seja, as relações existentes entre os seus diversos setores. Permitiu também a análise da rede externa, aquela referente aos vínculos estabelecidos entre a instituição avaliada e as que se situavam em torno do seu território de atuação. Para avaliarmos o Mapa da Rede Institucional Interna, criamos quadrantes que representavam os diversos setores que compunham a instituição, de acordo com a especificidade de cada situação. Em seguida, adotamos linhas com cores diferenciadas que indicavam a qualidade dos vínculos existentes entre cada setor. Apresentamos a descrição conforme Ude (2008).

- Vínculos significativos - no caso das relações institucionais, tanto internas como externas, representam parcerias extremamente cooperativas. O traço utilizado foi uma linha verde, como demonstrado a seguir:

Vínculos significativos :

- Vínculos fragilizados - são vínculos que se encontram tênues devido a diversos fatores. A representação gráfica ocorreu por meio do desenho de uma linha amarela, conforme a seguir: Vínculos fragilizados:

- Vínculos rompidos ou inexistentes - procuramos mapear instituições que pertenciam à comunidade e, em seguida, avaliamos aqueles vínculos que foram rompidos e os inexistentes. Nesses casos, simbolizamos o vínculo, utilizando uma linha vermelha, como se vê a seguir: Vínculos rompidos ou inexistentes: 
A representação gráfica do Mapa visou à identificação da qualidade dos vínculos e sua distribuição entre os quadrantes. Nesse aspecto, tentamos avaliar se a rede estava reduzida, mediana ou ampliada. De acordo com Sluzki (1997), uma rede mediana e bem distribuída entre os quadrantes tende a gerar fatores de proteção. Uma rede muito ampliada pode dificultar a articulação de apoios mais consistentes no cotidiano da vida dos sujeitos e das instituições. Entretanto, uma rede que apresenta lacunas na sua constituição aponta aspectos preocupantes que necessitam ser trabalhados.

O Mapa da Rede Institucional Externa evidenciou a constituição dos vínculos entre a instituição avaliada e os grupos organizados na comunidade, como também as distintas instituições governamentais e não governamentais, com o objetivo de procurar identificar recursos e lacunas existentes, com vistas a integrar, fortalecer e otimizar a rede comunitária existente.

De modo operacional, colocamos o nome da instituição estudada no centro do Mapa e verificamos os vínculos próximos, intermediários e distantes. A qualidade dos vínculos foi sinalizada pelas mesmas linhas analisadas anteriormente para se referir aos vínculos significativos, fragilizados, rompidos ou inexistentes. Ao término dessa parte, iniciamos a avaliação do desenho por meio dos seguintes critérios estabelecidos por Ude (2008):

- Tamanho: verificamos a quantidade de vínculos institucionais estabelecidos. Sendo assim, a rede pôde ser classificada como reduzida, mediana ou ampliada.

- Densidade: avaliamos a qualidade dos vínculos observados no que tange às linhas do traçado. Uma rede com boa densidade apresentou mais vínculos significativos nos seus quadrantes.

- Distribuição/composição: refere-se ao número de instituições situadas em cada quadrante. Aqui, observamos lacunas e recursos existentes na rede.

- Dispersão: tratamos da distância geográfica entre instituições. Esse fator pode dificultar contatos e apoios mútuos no cotidiano dos sujeitos.

Entre esses itens de análise, buscamos outros componentes importantes para o fortalecimento de um trabalho comunitário pautado por parcerias solidárias. O compartilhamento de recursos e de saberes constitui noção básica para a consolidação desse propósito. Podemos citar em nosso estudo:

- companhia social: parte do princípio de que isolados somos frágeis, tanto como pessoa quanto como instituição. Refere-se às necessidades e às possibilidades de atividades coletivas e compartilhadas, as quais propiciam inúmeras alternativas e estratégias para se enfrentar problemas diários; 
- ajuda material e de serviços: o compartilhamento de recursos materiais (veículos, alimentos, salas, quadras etc.) e de conhecimentos constitui a materialização de uma proposta em redes;

- acesso a novos contatos: o envolvimento junto a redes cooperativas e solidárias possibilita a construção de novos vínculos com pessoas e grupos, ampliando a rede social dos indivíduos e das instituições.

Ude (2008) refere que cada realidade social e comunitária produz desenhos próprios, conforme a peculiaridade de cada lugar. Todavia, essa diversidade não impediu a identificação de fatores de proteção e de fatores de risco, diante de recursos e de lacunas identificadas nas instituições avaliadas.

Outro recurso desenvolvido junto ao desenho produzido com o sujeito foi a realização de entrevista semiestruturada que, segundo Minayo (2007), combina perguntas fechadas e abertas em que o entrevistado tem a possibilidade de discorrer sobre o tema em questão sem se prender à indagação formulada. As entrevistas foram gravadas em MP3 e os sujeitos foram abordados com questões norteadoras pela pesquisadora, as quais sofreram variações conforme os Mapas construídos:

- Qual a articulação dos diversos setores da escola entre si e com as demais organizações?

- De que forma setores como saúde, educação, cultura, esportes, serviço social, justiça e políticas, têm contribuído para a prevenção e para o tratamento da violência escolar?

Após cada entrevista, as falas foram transcritas integralmente. Para análise dos dados obtidos, apoiamo-nos no referencial de Análise de Conteúdo modalidade Análise Temática, segundo Minayo (2010), em que a Análise de Conteúdo desdobra-se nas etapas de PréAnálise decomposta em Leitura Flutuante, Constituição do Corpus, Formulação e Reformulação de Hipóteses e Objetivos, seguida pela segunda etapa que constitui a Exploração do Material e, finalmente, Tratamento dos Resultados Obtidos e Interpretação. Pautada na mesma autora, a pesquisadora, após uma leitura flutuante, pôde estabelecer a forma de categorização. A Análise Temática consistiu em descobrir os núcleos de sentido que compunham uma comunicação, cuja presença ou frequência significassem alguma coisa para o objeto analítico visado. 


\subsection{Questões Éticas}

Para a realização deste estudo, houve apreciação e aprovação pelo Comitê de Ética em Pesquisa da Escola de Enfermagem de Ribeirão Preto-Universidade de São Paulo (EERPUSP), protocolo $n^{0}$ 1218/2010. Não fizemos referência institucional; a autorização dos diretores dessas instituições foi garantida para que pudéssemos proceder à pesquisa (APÊNDICE A) e os princípios éticos com seres humanos foram atendidos de acordo com as especificações da Resolução 196/96 (BRASIL, 1996a).

Anteriormente à coleta de dados, estabelecemos contato com o campo de estudo, quando explicamos aos sujeitos todos os aspectos relativos ao trabalho, apresentamos o Termo de Consentimento Livre e Esclarecido (APÊNDICE B) e solicitamos assinatura do mesmo após os devidos esclarecimentos. 


\section{RESULTADOS E DISCUSSÃO}

\subsection{Caracterização das Escolas}

Inicialmente, descrevemos as condições socioeconômicas encontradas nos bairros onde se situam as escolas analisadas. Isso permitiu uma melhor compreensão da realidade vivenciada pelas mesmas, assim como por seus alunos. Os dados são de 2010, provêm de cadastros socioeconômicos da Secretaria Municipal de Habitação de Alfenas e de um estudo feito pela Fundação de Ensino e Tecnologia de Alfenas (FETA), que permitiu a elaboração do Plano Local de Habitação de Interesse Social (PLHIS).

A escola A situa-se em um bairro antigo, formado há cerca de 80 anos, localizado na parte Sudeste da cidade a aproximadamente $700 \mathrm{~m}$ do centro, numa área quase toda urbanizada. As casas são em sua maioria boas para habitação, apesar de serem encontradas casas em péssimo estado de conservação e casos de coabitação (mais de uma família morando na mesma casa). Residem no bairro atualmente cerca de 800 famílias, a maioria das classes média e alta, contando aproximadamente 3.200 pessoas nas mesmas. O bairro conta com um campo de futebol onde são observadas atividades esportivas e não há conhecimento de movimentos culturais ou outros grupos organizados.

O bairro onde se encontra a escola $B$ se localiza na parte Norte da cidade a aproximadamente $4 \mathrm{Km}$ do centro; foi formado há cerca de 40 anos e trata-se de um dos primeiros conjuntos habitacionais efetivados pela Companhia de Habitação Popular (COHAB) em convênio com a Prefeitura. Moram no bairro atualmente cerca de 400 famílias, a maioria das classes média e baixa, contando aproximadamente 4.100 pessoas nas mesmas. As casas dessas famílias são em sua maioria precárias, embora tenham sido implantados no bairro dois novos conjuntos habitacionais. A situação do bairro e da área do entorno é completa em relação à assistência quanto à água, à iluminação pública, à energia elétrica nos domicílios, à pavimentação, ao esgoto, à coleta de lixo, ao transporte coletivo etc.

A escola C localiza-se na região central, cuja área é toda urbanizada, sendo o bairro mais antigo da cidade, formado há mais de 120 anos. As casas são muito diversas, variando entre ótimas, boas, regulares, ruins e péssimas para habitação; sendo que as ruins e péssimas são a minoria. É a região mais dinâmica da cidade, contando com diversos equipamentos sociais, prédios públicos, comércios, praças, bancos, áreas de lazer, entre outros. Moram no 
bairro atualmente cerca de 2.000 famílias, a maioria das classes média e alta, contando aproximadamente 8.000 pessoas nas mesmas. A maioria das atividades culturais e dos grupos desse segmento estão localizados nesse bairro, sendo que a população do mesmo participa de forma ativa dessas atividades, tais como teatro, jogos, festas típicas, shows, entre outros.

A escola D encontra-se no bairro localizado na parte Oeste da cidade a aproximadamente $4 \mathrm{Km}$ do centro, tendo surgido há cerca de 30 anos a partir de loteamento formado pela COHAB em convênio com a Prefeitura. Moram no bairro atualmente cerca de 800 famílias, a maioria de baixa renda, contando aproximadamente 2.500 pessoas nas mesmas, sendo que suas casas são em sua maioria precárias em termos de tamanho e estado de conservação. O bairro conta com um complexo esportivo com várias quadras onde existem atividades regularmente.

Formado há cerca de 20 anos, no bairro ao qual pertence a escola E, as casas são em sua maioria de boas a ótimas em relação a sua tipologia, tamanho e divisão dos cômodos, quase não sendo encontrados casebres, barracos ou moradias coabitadas. Não são observadas ações de grupos culturais, associações ou ONGs, nem mesmo existem atividades dessa natureza desenvolvidas pelo poder público. Residem no bairro atualmente uma média de 400 famílias, contando aproximadamente 1.600 pessoas.

Finalmente, a escola F está localizada num bairro formado há cerca de dez anos. As famílias que nele residem são em sua maioria das classes baixa e média. As casas do bairro são novas em relação ao tempo de construção, mas em sua maioria são pequenas, muitas inacabadas (sem reboco por fora, sem pintura, sem acabamento interno, etc), quase não sendo encontrados casebres, barracos ou moradias em péssimo estado de conservação. Não são observadas ações de grupos culturais, associações, ONGs ou poder público. Moram no bairro atualmente cerca de 500 famílias, contando aproximadamente 2.100 pessoas.

De modo geral, o quadro de funcionários das escolas é composto por diretor, vicediretor, supervisor pedagógico, orientador, secretários, professores e ajudantes de serviços gerais.

A escola A possui apenas ensino médio e as outras cinco apresentam ensinos fundamental e médio. Em seus espaços internos, convivem alunos de diversas classes sociais, sendo que os de ensino médio somam aproximadamente 4.000 matriculados, com faixa etária média entre 15 e 18 anos. As escolas A, D, E e F apresentam também a Educação de Jovens e Adultos (EJA), a qual é a modalidade de ensino nas etapas dos ensinos fundamental e médio da rede escolar pública brasileira e adotada por algumas redes particulares que recebem os jovens e adultos que não completaram os anos da educação básica em idade apropriada por 
qualquer motivo (entre os quais é frequente a menção da necessidade de trabalho e a participação na renda familiar desde a infância). No início dos anos 1990, o segmento da EJA passou a incluir também as classes de alfabetização inicial. O segmento é regulamentado pelo artigo 37 da Lei de Diretrizes e Bases da Educação Nacional (LDB) (BRASIL, 1996b).

\subsection{Caracterização dos Sujeitos}

Encontramos um total de 13 supervisores pedagógicos, os quais são especificados a seguir conforme a quantidade por turno de serviço: escola A (um matutino, um vespertino, um noturno); escola B (um matutino); escola C (dois vespertinos); escola D (um matutino, um vespertino); escola E (um matutino, um vespertino, um noturno); escola F (um matutino, um noturno). Desses, um do período vespertino da escola A, um do período vespertino da escola $\mathrm{D}$, um do período vespertino da escola $\mathrm{E}$ e um do período matutino da escola $\mathrm{F}$ ocupavam a função há menos de um ano na instituição e, por essa razão, não puderam fazer parte do estudo, atendendo ao critério de exclusão. Portanto, contamos com a colaboração de nove sujeitos, sendo aplicado o Mapa Mínimo da Rede Social Institucional (UDE, 2008) e acrescentando informações por meio de entrevista, ambos previamente agendados.

Do total de supervisores que participaram do estudo, apenas um é do sexo masculino. A idade dos mesmos encontra-se na faixa de 32 a 53 anos. Conforme o artigo 64 da LDB (BRASIL, 1996c), a formação de profissionais de educação para a administração, o planejamento, a inspeção, a supervisão e a orientação educacional para a educação básica, deve ser feita em cursos de graduação em Pedagogia ou em nível de Pós-Graduação, a critério da instituição de ensino, garantida, nessa formação, a base comum nacional. Todos os sujeitos apresentam graduação em Pedagogia no mínimo há quatro anos e, no máximo, há 24 anos, bem como a titulação de supervisores e orientadores. Oito apresentam também as seguintes especializações: Metodologias Inovadoras Aplicadas à Educação (um sujeito); Metodologias do Ensino (dois sujeitos); Didática do Ensino (um sujeito); Mestre em Administração de Negócios, Master Business Administration, (MBA) em Gestão de Capital (um sujeito); Educação Empreendedora (um sujeito); Psicologia Esportiva (um sujeito); Psicopedagogia (um sujeito). O tempo mínimo de atuação na supervisão encontrado foi de dois anos e, o máximo, 15 anos. Oito sujeitos trabalham em mais de um período, ocupando funções distintas e, geralmente, em instituições diferentes daquelas em que atuam como supervisores. Cinco 
deles são professores regentes de sala; um é professor de matérias específicas (Filosofia e Sociologia); dois são bibliotecários na mesma escola em que ocupam o cargo de supervisão, sendo que, um dos dois também exerce a supervisão em outra instituição. Não há nenhum treinamento específico pelo qual todos os profissionais passem com a finalidade de se prepararem sobre a temática da violência.

\subsection{A Construção dos Núcleos Temáticos}

A apresentação dos resultados obtidos na elaboração dos Mapas e entrevistas visou à complementariedade para o alcance dos objetivos deste estudo. A análise dos mesmos, bem como as observações de campo originaram os seguintes Núcleos Temáticos: A Escola e a Violência; Enfrentamento da Violência Escolar. O segundo Núcleo Temático teve como subtemas: Ações Internas e A Atuação em Rede.

\subsubsection{Núcleo Temático: A Escola e a Violência}

Ainda hoje, ao falarmos de escola, temos a ideia de que a mesma é a responsável pela transmissão do ensino formal e do saber erudito para crianças e adolescentes. Todavia, o processo histórico, as mudanças políticas, sociais e relacionais alteraram o cenário escolar, levando-nos a reconhecer que compreender a escola significa compreender o contexto em que a mesma se encontra inserida, seu local geográfico, sua clientela, seus funcionários, bem como as relações que se estabelecem interna e externamente.

Conforme Faria Filho e Vidal (2000), o período colonial legou-nos um número muito reduzido de escolas régias ou de cadeiras públicas de primeiras letras, constituídas, sobretudo, a partir da segunda metade do século XVIII. Com professores reconhecidos ou nomeados como tais pelos órgãos de governos responsáveis pela instrução, essas escolas funcionavam em espaços improvisados. Segundo os autores, em meados da última década do século XIX, primeiro em São Paulo e, depois, em alguns estados brasileiros, foi assumida a forma mais acabada da proposta dos grupos escolares. 
Neles, e por meio deles, os republicanos buscaram dar a ver a própria República e seu projeto educativo exemplar e, por vezes, espetacular. Não era casual que as edificações escolares fossem construídas visando à monumentalidade, por outro lado, a construção de espaços escolares era reclamada em boa parte das capitais das demais unidades da Federação (FARIA FILHO; VIDAL, 2000, p. 24).

Tempos depois, ainda hoje no Brasil, afirmam os mesmos autores, não há prédios escolares, nem distribuição de material escolar, como carteira a todo território nacional. As escolas existentes nas grandes cidades, principalmente, são pichadas, demonstrando claramente a pouca identidade dos alunos com o espaço físico que ocupam. Feios, cercados por muros altos e muitas vezes com grades e cadeados, os prédios escolares assemelham-se a espaços de reclusão.

Oliveira (2009) constatou a depredação das escolas que antes se manifestava em patrimônios privados e, atualmente, mostra-se também nas instituições públicas, as quais canalizam, semestralmente, verbas de reparação aos danos causados pelos discentes que abrangem a quebra de cadeiras, de mesas, de vidraças, as pichações e outras destruições dentro do espaço que deveria viabilizar o ensino e a aprendizagem.

O espaço físico escolar é carregado de significados, de valores, de símbolos culturais e ideológicos, os quais são apreendidos pelos alunos e despertam diferentes sentimentos. Como bem afirmou um dos sujeitos entrevistados:

(...) diante de uma escola bem cuidada, o aluno sente satisfação em conservar o ambiente pelo fato do mesmo ser agradável. (S 07)

Todavia, um estudo com amostra de 446 alunos e 120 professores, representativo de oito escolas públicas do ensino fundamental e médio do Estado do Maranhão, identificou que $70 \%$ dos alunos não gostam do local (da rua, do bairro e da vizinhança) onde a escola está situada, por considerarem o seu entorno "perigoso". As dependências da escola, de modo geral e, particularmente, a sala de aula são vistas por 22,4\% dos alunos e por $20,8 \%$ dos professores como espaços onde também ocorre violência (MACEDO; BOMFIM, 2009).

Miranda (2004), ao estudar escolas urbanas públicas e privadas da rede de ensino médio do município de Ribeirão Preto do Estado de São Paulo, constatou como causas que agravam as manifestações de violência, a localização da escola; o sucateamento físico da mesma; a falta de equipamentos e de manutenção; o clima atmosférico escolar; o tamanho da escola; a quantidade de turmas e alunos; a importação de alunos de outros bairros, a qual ocorreu com a reforma do sistema de ensino, em que foram estabelecidos ciclos, com alguns alunos remanejados para escolas não pertencentes ao seu bairro. 
Nas escolas onde o estudo foi realizado, conseguimos observar espaços físicos amplos e prédios em diferentes condições de conservação, destacando que a escola F assumiu o ensino médio há pouco mais de um ano, apresentando instalações recentes.

Chrispino e Dusi (2008) afirmam que a escola é o espaço que a sociedade acredita ser o ideal para reproduzir seus valores considerados importantes para a sua manutenção. Ocorre que a escola passou por algumas transformações, dentre as quais o ensino deixou de ser familiar e difuso para ser institucional; houve a criação dos sistemas escolares públicos em que o Estado passou a atuar no processo de transmissão organizada do conhecimento e, por fim, ocorreu a massificação da educação que, no Brasil, caracteriza-se pelo índice médio superior a $97 \%$ de crianças no ensino fundamental. Tais transformações trouxeram para o universo escolar uma diversidade de alunos, tendo em vista que o modo de formação dos professores não os preparou adequadamente para lidar diante dessas mudanças. Por essa razão, surgem antagonismos que se transformam em conflitos e que podem chegar aos extremos da violência. Camacho (2000) aponta duas formas básicas de violência na escola: física (brigas, agressões físicas e depredações) e não física (ofensas verbais, discriminações, segregações, humilhações e desvalorização com palavras e atitudes de desmerecimento), sendo a última, muitas vezes, disfarçada, mascarada e de difícil diagnóstico.

Quando abordados sobre as manifestações de violência escolar, grande parte dos sujeitos referiu que tais manifestações são de pequena extensão, limitando-se a discussões entre alunos, as quais envolvem professores em determinadas situações. Todavia, essas discussões foram relatadas como algo natural, justificável pelas divergências natas entre seres humanos ou, até mesmo, pela fase do desenvolvimento em que os alunos se encontram. Por serem resolvidas dentro do próprio espaço escolar após algumas conversas, sem necessidade de intervenção policial, na visão dos sujeitos, não oferecem grande preocupação. Silva e Salles (2010) descrevem um resultado semelhante encontrado em seu trabalho em que os tipos de violência assinalados pelos professores como estando mais presentes no dia a dia escolar são as ameaças e agressões verbais entre alunos e entre estes e os adultos. As autoras indicam que a violência na escola está banalizada, provocando inclusive que vários atos deixem até de ser percebidos como violentos.

(...) a gente não depara hora nenhuma com grande violência, tem discussões entre um coleguinha e outro, mas é coisa que com conversa a gente resolve aqui mesmo entre eles, acabam pedindo desculpa, arrependendo daquilo, chegando numa conclusão e morre 
por aqui, nunca chegou a levar para a polícia, apesar de ser periferia (...). (S 08)

Discute, sim, discute com professor, desentende, cada ser humano tem sua opinião, tem hora que não bate, mas também começa e morre por aí, não tem seguimento, agressão de forma física, nem de parte do professor, nem de parte do aluno, aluno versus aluno, nem professor versus aluno, acho que ainda estamos dando sorte. (S 08)

Esse ano, a gente tem mais (problema de violência), mas é tudo da fase deles mesmo, da adolescência e com conversa está resolvendo, não sei até quando vai ser assim (...). (S 09)

Os alunos aos quais os sujeitos se referem são considerados adolescentes conforme o ECA (BRASIL, 1990a), artigo 2, que diz “considera-se criança, para os efeitos desta Lei, a pessoa até 12 (doze) anos de idade incompletos, e adolescente aquela entre doze e dezoito anos de idade.”. Priotto (2006) assevera que o termo adolescência, proveniente do latim adolescere, representa um período em que coexistem grandes mudanças e crises tanto de forma física, psíquica como socialmente para se tornar um adulto.

Para Winnicott (1987), a violência manifestada na adolescência é chamada de "Violência salutar”, própria dessa fase e se caracteriza por ser uma violência desafiadora, intempestiva, irresponsável, lúdica, provocadora, criativa e transgressora. Por outro lado, conforme Priotto (2006), os professores, ao conhecerem as mudanças corporais, emocionais e psicológicas dessa fase do desenvolvimento, apresentarão menor ansiedade no relacionamento com os alunos, facilitando o envolvimento entre ambos.

A presença e o envolvimento da escola na vida do adolescente podem ser lembrados no artigo 53 do ECA (BRASIL, 1990b), que afirma o direito de crianças e adolescentes à educação, visando ao pleno desenvolvimento de sua pessoa, ao preparo para o exercício da cidadania e à qualificação para o trabalho, assegurando-lhes, dentre outros aspectos, a igualdade de condições para o acesso e a permanência na escola; o direito de serem respeitados por seus educadores e direito de contestar critérios avaliativos, podendo recorrer às instâncias escolares superiores.

Ressaltamos também o artigo 35 da seção IV da LDB (BRASIL, 1996d), parágrafos II e III, no que se refere ao ensino médio, o qual apresenta que o mesmo terá como finalidades: 
II - a preparação básica para o trabalho e a cidadania do educando, para continuar aprendendo, de modo a ser capaz de se adaptar com flexibilidade a novas condições de ocupação ou aperfeiçoamento posteriores;

III - o aprimoramento do educando como pessoa humana, incluindo a formação ética e o desenvolvimento da autonomia intelectual e do pensamento crítico.

Para Santos et al. (2011), a presença da violência no contexto escolar, envolvendo discentes e docentes deve ser inegavelmente reprovada, tendo em vista que a escola é o local na sociedade onde se deve apreender a disciplina. Representa o conhecimento; a extensão do lar; o ambiente apropriado para a continuidade da formação do caráter do indivíduo; a condição fundamental para o desenvolvimento pessoal, profissional e intelectual. E o docente representa a figura do educador, do mediador do conhecimento, aquele que, por participar efetivamente da vida do discente, merece, ou pelo menos deveria merecer, respeito e amabilidade.

Observamos que, nas representações dos sujeitos, o fenômeno violência é compreendido com dificuldade, de forma limitada, implicando, na maioria das vezes, danos físicos. Contudo, retornando ao conceito de violência adotado neste trabalho proveniente da WHO (2002), o fenômeno abrange desde lesão e morte até danos psíquicos, alterações do desenvolvimento ou privações. Silva e Salles (2010) reforçam esse conceito ao dizerem que em geral, a violência é conceituada como um ato de brutalidade, física e/ou psíquica contra alguém e caracteriza relações interpessoais descritas como de opressão, intimidação, medo e terror. Afirmam que a violência não pode ser reduzida ao plano físico, podendo se manifestar também por signos, preconceitos, metáforas, desenhos, isto é, por qualquer coisa que possa ser interpretada como aviso de ameaça, o que ficou conhecido como violência simbólica.

A questão da violência na escola não deve ser enunciada somente em relação aos alunos, deve ser analisada também a capacidade de a escola e de seus agentes suportarem e gerarem situações conflituosas, sem esmagar os alunos sob o peso da violência institucional e simbólica (CHARLOT, 2002).

As situações de violência que ocorrem no interior das escolas suscitam, em muitos casos, a presença de força policial, colocando em evidência a dificuldade dos docentes de exercer sua autoridade para resolver os conflitos (RISTUM; BASTOS, 2004). Spósito (2001), ao fazer um balanço das pesquisas referentes à violência escolar no Brasil, destaca que a relação conflituosa entre alunos e professores tem gerado um medo constante entre professores, que apelam para a segurança policial, o que afeta a qualidade da interação educativa e o clima escolar. Segundo Ristum e Bastos (2004), as “briguinhas” entre colegas cederam espaço às graves agressões físicas e verbais entre eles e entre discentes e docentes, muitas vezes com o porte de armas de diversos 
tipos. Para as autoras, o que é presenciado hoje é fruto de um quadro que ainda não foi devidamente compreendido. Uma profunda crise de identidade da instituição escolar e, por consequência, dos atributos existentes na relação docente-discente.

Um estudo realizado em Portugal (SEBASTIÃO; ALVES; CAMPOS, 2003) considerou que é dentro do campo pedagógico que a violência pode ser resolvida, ou pelo menos prevenida, dando importância reduzida a medidas baseadas no uso do policiamento dentro dos limites da escola. A estratégia defendida é centrada na promoção das competências sociais e na formação cívica e educativa dos alunos, os quais, em determinadas situações, diante da frustração, manifestam-se por meio de atos violentos por não serem capazes de lidar com o insucesso e por se sentirem agredidos durante o seu percurso escolar.

\subsubsection{Núcleo Temático: O Enfrentamento da Violência Escolar}

Em vários momentos da pesquisa em campo, os sujeitos consideraram os alunos sem limites, desrespeitosos, desacatando normas e tendo a escola e seus agentes como um problema.

Os alunos estão vindo como se o professor fosse um problema para eles, não aceitam regras, normas da escola, eles não respeitam nada, acham que o que pensam e como fazem está certo (...). (S 06)

Charlot (2002) afirma que, nos últimos anos, os pesquisadores franceses desenvolveram uma distinção entre violência, transgressão e incivilidade. O termo violência deve ser reservado ao que ataca a lei com o uso da força ou ameaça usá-la: lesões, extorsão, tráfico de drogas na escola, insultos graves. A transgressão é o comportamento contrário ao regulamento interno do estabelecimento (mas não ilegal do ponto de vista da lei); absenteísmo; não realização de trabalhos escolares; falta de respeito, etc. A incivilidade seria a contradição das regras de boa convivência: desordens, empurrões, grosserias, palavras ofensivas, geralmente ataque cotidiano e repetido ao direito de cada um (professor, funcionários, aluno). O autor considera essa distinção útil porque permite não misturar tudo em uma única categoria e designa diferentes lugares e formas de tratamento dos fenômenos. Assim, um tráfico de drogas não depende do conselho de disciplina do estabelecimento, mas 
da polícia e da justiça; inversamente, um insulto ao ensino deve ser tratado pelas instâncias do estabelecimento e não justifica que se chame a polícia. Quanto à incivilidade, ela depende fundamentalmente de um trabalho educativo. Todavia, continua o autor, essa distinção está ultrapassada em parte para descrever o que se passa hoje em alguns estabelecimentos escolares: de um lado, violências, transgressões e incivilidades estão, por vezes, intimamente misturadas nos comportamentos cotidianos; de outro, o acúmulo de incivilidades cria um clima em que professores e alunos se sentem atingidos em sua identidade pessoal e profissional, ataque à dignidade que merece o nome de violência.

Encontramos vários estudos que referem o papel essencial dos professores na prevenção e resolução dos casos de violência, todavia lembramos a formação deficiente de muitos profissionais da educação que os impede de atuar com segurança diante das manifestações de violência. Priotto (2009) afirma que diminuir a violência escolar é um desafio para os professores, pois exige conhecimento didático, valores morais e éticos e também uma grande capacidade de comunicação, de empatia, de respeito à identidade do outro para auxiliar o aluno a construir o caminho. A autora acrescenta a necessidade de investimento no professor, no seu aperfeiçoamento, pois “ninguém conseguirá educar o outro, sem antes educar-se a si mesmo”.

(...) tem aluno que precisava de uma assistência e a gente não tem como dar essa assistência aqui na escola. (S 02)

Njaine e Minayo (2003) referem em seu estudo que os educadores afirmaram que deveriam discutir com os alunos sobre a exposição deles à violência, buscando formas de prevenção, mas muitos não se julgam preparados para desenvolver esse tipo de atividade. Impotência, medo, angústia e revolta são sentimentos às vezes comuns entre os educadores que têm que lidar com a questão da violência na escola, no entorno e nas relações conflituosas que permeiam o ambiente escolar.

As autoras asseguram que o lugar da escola, como fonte privilegiada de mediação, assim como o da família, possibilita uma atuação ampla no campo da prevenção da violência. Mas é necessário que essas instituições caminhem juntas, buscando principalmente estabelecer uma relação respeitosa com os jovens.

Nos diferentes estudos, são inúmeras as tentativas de enfrentamento da violência escolar, a qual constitui uma problemática de grande dimensão. Santos et al. (2011) discutem que, ao lançar um olhar sobre a questão da violência escolar, encontram o entrelaçar da 
Pedagogia, da Psicologia, da Sociologia - enfim, das ciências humanas e sociais de uma forma geral - imbricadas e comprometidas com a sistematização e com a compreensão do fenômeno violência na escola.

Para Grange et al. (2006), a violência na escola perpassa questões bioéticas, tendo em vista que a bioética se ocupa do resgate da humanização das relações humanas e que o adolescente enfrenta grande instabilidade ao iniciar a construção de suas habilidades intelectuais, afetivas e sociais, tão necessárias a sua integração na comunidade adulta com autonomia, maturidade e independência. Os valores morais, éticos e sociais estão embaçados na visão do adolescente que se encontra confuso em meio às desigualdades sociais experienciadas, aos conflitos da idade, à busca por uma realização pessoal e às muitas impossibilidades, situação que gera sentimentos ambivalentes e à desorganização da malha social, culminando com tensão emocional, estresse e violência.

O campo das relações humanas permite a descoberta e a convivência com situações mútuas, que possibilitam o atuar ético ou não do ser humano. A diferença nessa atuação é desenvolvida no processo de formação, no qual o estabelecimento de vínculos, a convivência familiar, as experiências de convivência com o outro são elementos influenciadores deste processo (COHEN; GOBBETTI, 2004).

Os Parâmetros Curriculares Nacionais (PCN) apontam como meta o estímulo à ética nas unidades escolares, sendo ela responsável pela construção e pela tomada de decisão consciente dos discentes, exercendo preponderante papel no exercício da cidadania. Sendo assim, a bioética na escola pode levar o educando a compreender a necessidade de um contínuo pensar, refletir e construir, o que favorece o exercício da cidadania a partir do momento que impulsiona a problematização constante do viver pessoal e coletivo (BRASIL, 1998).

A escola, além de estar relacionada diretamente à construção de conhecimento, possui a responsabilidade e o compromisso na construção de uma sociedade mais cidadã, haja vista que a educação é capaz de transformar e emancipar o indivíduo para escolhas críticas e reflexivas, levando-o a aprender a aprender, a saber pensar, a informar-se e a refazer diariamente a informação, a questionar (DEMO, 2002).

Chrispino (2007) assevera que as escolas que valorizam o conflito e aprendem a trabalhar com essa realidade, são aquelas onde o diálogo é permanente, objetivando ouvir as diferenças para melhor decidirem; são aquelas onde o exercício da explicitação do pensamento é incentivado, objetivando o aprendizado da exposição madura das ideias por meio da assertividade e da comunicação eficaz; onde o currículo considera as oportunidades para discutir soluções alternativas para os diversos exemplos de conflito no campo das ideias, 
do poder, da posse, das diferenças de toda ordem; onde as regras, aquilo que é exigido do aluno nunca estão no campo do subjetivo ou do entendimento tácito: estão explícitos, falados e discutidos. Segundo o autor, é possível também pensar na introdução do tema mediação de conflito no currículo escolar, o que seria uma oportunidade para verbalizar a questão e tornar claro o que se espera do adolescente no conjunto de comportamentos sociais. De outra forma, é dizer ao adolescente e à criança que suas diferenças podem se transformar em antagonismos e que, se estes não forem entendidos, evoluem para o conflito, que deságua na violência.

Chrispino e Dusi (2008) apontam também as políticas públicas educacionais como prevenção da violência e pontuam aspectos que precisam ser lembrados. Primeiramente, a violência escolar é sistêmica e complexa. Por tal razão, não é razoável esperar que seja superada por ações pontuais; o fenômeno pede o desenvolvimento de uma capacidade de antecipação por meio de diagnóstico realista, análise prospectiva, planejamento com capacidade de aplicação, convergência de ações entre os diversos atores para o fim determinado, avaliação de processo e de resultado e, quiçá, responsabilização pelo feito e pelo não feito no assunto. Os autores afirmam que, enquanto ficarmos preocupados em encontrar culpados, pouco progrediremos na busca de soluções, afinal, o culpado, inexoravelmente, acaba sendo o outro. Outro aspecto importante é quanto ao momento para o qual se dirigem as políticas. Há propostas de formular políticas para solucionar problemas causados pela violência: expulsar estudantes; aumentar a altura dos muros; instalar detectores de metal; diminuir a idade penal; aumentar os espaços em instituições para menores infratores. Contudo, os autores recordam que, além de atender às consequências da violência escolar, existe a necessidade de se alcançar algumas de suas causas de modo a promover sua redução e a construção da Cultura de Paz no contexto da instituição educacional.

A Cultura de Paz é definida como um conjunto de valores, atitudes, tradições, comportamentos e estilos de vida baseados no respeito pleno à vida e na promoção dos direitos humanos e das liberdades fundamentais, propiciando o fomento da paz entre as pessoas, os grupos e as nações (ONU, 1999), podendo assumir-se como estratégia política para a transformação da realidade social.

Galheigo (2008) assevera que iniciativas para a prevenção da violência e para a sedimentação de uma Cultura de Paz passaram a ser entendidas como medidas fundamentais no âmbito dos setores educação, assistência social, saúde e segurança pública. A intersetorialidade tem se mostrado pertinente para lidar com a questão da violência, mas frequentemente as ações são limitadas aos setores específicos e se restringem à implementação de programas e de projetos isolados em escolas e em comunidades. 
Priotto (2006), ao abordar professores em Foz do Iguaçu sobre o que poderia ser feito para prevenir a violência escolar, os mesmos responderam: maior participação da família com a escola e interesse pela vida de seus filhos; mais tempo dos professores com seus alunos; menor número de alunos por sala; investir mais na educação; promover palestras, parcerias com ONGs, preparo dos professores; contratação de mais funcionários; redução da violência fora da escola; atividades extraclasse.

As propostas para a prevenção da violência nas escolas têm privilegiado diferentes aspectos. Ora essas propostas são norteadas por políticas públicas que apoiam a abertura das escolas aos finais de semana, ora são fundamentadas na prática das rondas escolares, ora se privilegiam ações e intervenções centradas no protagonismo juvenil. E, ora na proposição de estratégias que contribuam para a resolução de conflitos e para o incentivo ao estabelecimento de relações democráticas na escola. Tais estratégias são centradas no cotidiano escolar e com uma proposta de intervenção voltada a educar os agentes escolares, alunos, professores, diretores e funcionários, a lidar com as pequenas agressões cotidianas que aparecem no desrespeito, na segregação, na exclusão e na indiferença ao outro. Ou seja, são propostas que buscam desenvolver estratégias de intervenção para as pequenas violências que ocorrem constantemente no âmbito escolar (SILVA; SALLES, 2010).

Até o momento, abordamos a importância de trabalharmos o modo de pensar de crianças e de adolescentes, bem como das famílias e da comunidade, contando com a atuação conjunta dos diversos setores envolvidos na temática, além da necessidade de políticas educacionais. Em outras palavras, discorremos sobre a atuação em rede, a qual constitui o objeto de nosso estudo, sendo almejada como mais viável para o enfrentamento dos casos de violência escolar.

Recordamos que a rede social é definida como conjunto de sistemas e de pessoas significativas que compõem os elos de relacionamento recebidos e percebidos do indivíduo ou da instituição, como ocorre no nosso caso (BRITO; KOLLER, 1999). Siqueira, Betts e Dell’Aglio (2006) discutem que a rede social está associada à saúde e auxilia no enfrentamento das situações de estresse, sendo capaz de sofrer constantes alterações.

Ainda que o conceito de rede seja utilizado para fazer referência a distintas realidades, apresenta, no entanto, como ideia comum, a imagem de pontos conectados por fios, de modo a formar a imagem de uma teia. Pensar uma sociedade em rede significa entendê-la na sua interdependência e em seu policentrismo (OLIVEIRA, 2000a).

Dabas (1998) lembra que, quando ocorre uma perda no sentimento de segurança, recursos internos e externos são buscados para a superação daquilo que está sendo vivenciado. Esse processo torna-se mais complicado quando a inserção ativa na rede está obstruída. 
O apoio social que as redes proporcionam remete ao dispositivo de ajuda mútua, potencializado quando uma rede social é forte e integrada. Quanto aos aspectos positivos das relações sociais, podemos destacar o compartilhamento de informações e o auxílio em momentos de crise (ANDRADE; VAITSMAN, 2002).

Com base no que foi apresentado, reconhecemos a importância da atuação em rede, com o propósito de fortalecimento das escolas, facilitando o estabelecimento de funções, a definição de papéis e sentimentos de segurança diante desse fenômeno amplo, complexo e que merece especial atenção, a violência escolar.

\subsubsection{Subtema: Ações Internas}

Oliveira (2009) afirma que as instituições escolares geralmente não possuem propostas específicas para o enfrentamento da questão da violência. Dessa forma, os profissionais da educação desenvolvem seus trabalhos sem formação adequada nessa área, agindo com base em suas intuições, resultando em ações nem sempre eficazes. O autor afirma, ainda, que as dificuldades encontradas, na maioria das vezes, relacionam-se à impossibilidade de propiciar aos alunos experiências e práticas educativas que favoreçam a formação ética e moral dos discentes, com redução dos comportamentos indesejados.

Abramovay (2003) assevera que a formação dos profissionais de educação e as propostas pedagógicas das escolas não colaboram na constituição de profissionais preparados para lidar com as situações conflituosas do ambiente escolar contemporâneo.

Nas seis escolas estudadas, ao questionarmos as ações assumidas para o enfrentamento da violência, os supervisores afirmaram que essas instituições buscam estratégias próprias para a resolução dos casos detectados. A princípio, aplicam advertência verbal ou escrita, comunicam pais ou responsáveis e, quando necessário, em situações que ultrapassam a sua capacidade de atuação, entram em contato com o Conselho Tutelar, com a Guarda Municipal e, até mesmo, com a Promotoria Pública. Um dos sujeitos ainda referiu que, para não chegar ao extremo de sair dos limites escolares, os supervisores dialogam com os alunos, utilizando técnicas que têm os conflitos cotidianos como foco para que esses alunos busquem a mudança dos hábitos tidos como inapropriados.

A gente tem aqui dentro da escola a advertência, essa advertência pode ser verbal ou por escrito. Todo tipo de agressão a gente 
comunica aos pais, dependendo a gente entra em contato com o Conselho e a Guarda Municipal. Quando esse padrão nos foge, nós vamos atrás da Promotoria (...). (S 01)

(...) eu faço uma orientação individual com ele (o aluno em situação de violência), aí eu crio dinâmica a partir do conhecimento dele, do que ele me passa, eu uso assim muitas parábolas, fábulas, histórias que tiram lição de vida e converso com ele. (S 02)

O fluxograma abaixo representa o encaminhamento dos casos de violência realizado pelas escolas:

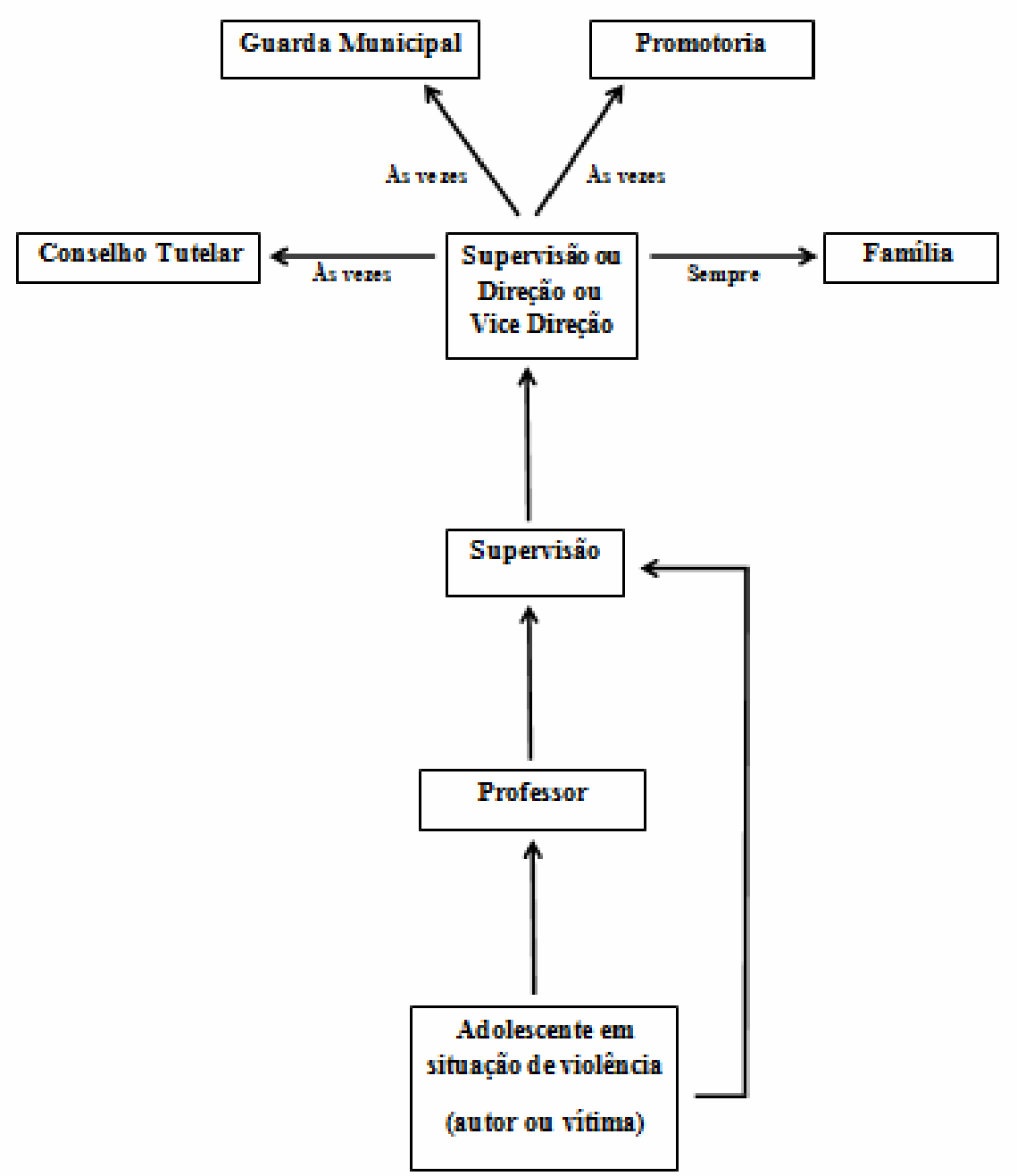

Figura 4 - Fluxograma dos casos de violência na escola 
No que concerne à interação entre os funcionários nas escolas, por mais que exista uma hierarquia, dos nove sujeitos abordados, oito referiram satisfação quanto ao relacionamento, que facilita o trabalho desempenhado, por haver liberdade de atuação, mantendo, contudo, a segurança de se apoiarem uns aos outros quando os problemas existentes não podem ser resolvidos de forma efetiva individualmente. Apenas um sujeito manifestou que direção e vice-direção limitam as suas ações. Porém, a impressão que nos foi transmitida, levou-nos a pensar que tal descontentamento ultrapassa o campo profissional, podendo esconder alguma divergência particular do sujeito.

A nossa escola funciona com primeiro o diretor, que é a autoridade máxima, posteriormente vem a vice, supervisor e tudo isso visa ao aluno, não esquecendo também a presença fundamental dos professores. (S 01)

(...) a escola para nós é um todo, desde a pessoa da faxina até o diretor, todos eles são instruídos para trabalhar na escola (...). (S 01)

A gente tem uma ligação boa, a gente consegue trabalhar muito bem, boa mesmo. (S 05)

Por mais complexo que seja lidar com a violência, as escolas tentam. Se não fazem mais ou de uma forma melhor, é porque não aprenderam o caminho a seguir, afinal, acreditamos que ninguém tem a pretensão de falhar, ainda mais quando falamos de educação, de formação para a vida.

Conforme Oliveira (2009, p. 221):

Somente a partir de uma conscientização dentro desse contexto, por meio de ações conjuntas e na mesma direção, que promovam a melhoria das relações interpessoais e enfatizem a atenção aos valores morais e éticos, como o respeito, a solidariedade, o companheirismo, o diálogo e a cooperação entre os pares, pode-se minimizar e prevenir o fenômeno da violência escolar.

Oliveira (2009) acrescenta que a formação básica e continuada apresenta fundamental importância. Os educadores devem dedicar-se, aprofundando-se em pesquisas específicas, assim como em conhecimentos provenientes de pesquisas especializadas sobre educação e sobre violência. O autor supracitado lembra também a importância do diálogo em sala de aula 
para o desenvolvimento de todos os envolvidos, promovendo um clima saudável nas relações escolares.

\subsubsection{Subtema: A Atuação em Rede}

Para termos um panorama geral da atuação em rede a partir das escolas, apresentamos os Mapas dos vínculos institucionais elaborados pelos sujeitos, segundo a proposta de Ude (2008).

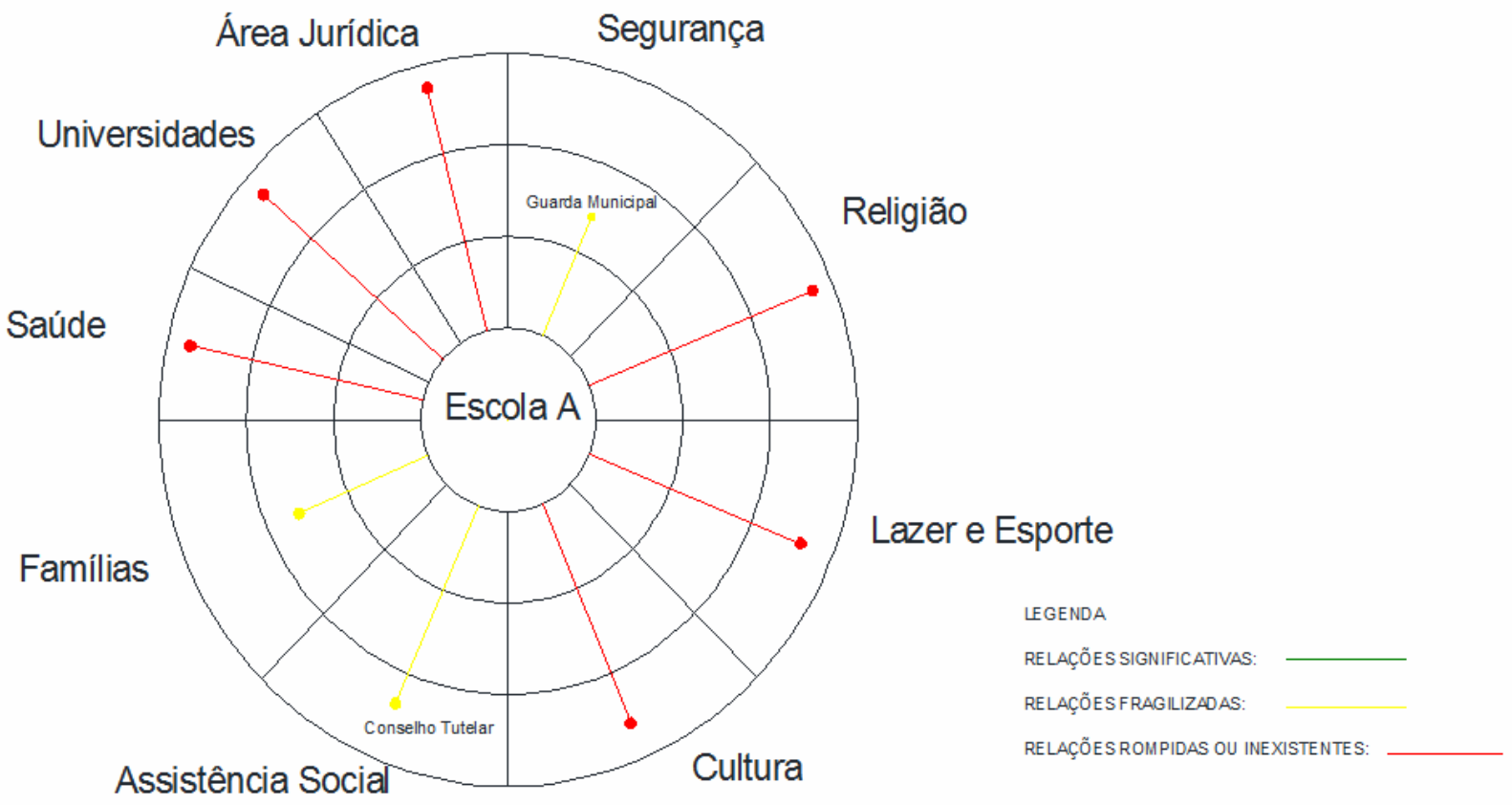

Figura 5 - Mapa Mínimo da Rede Social Externa da Escola A 


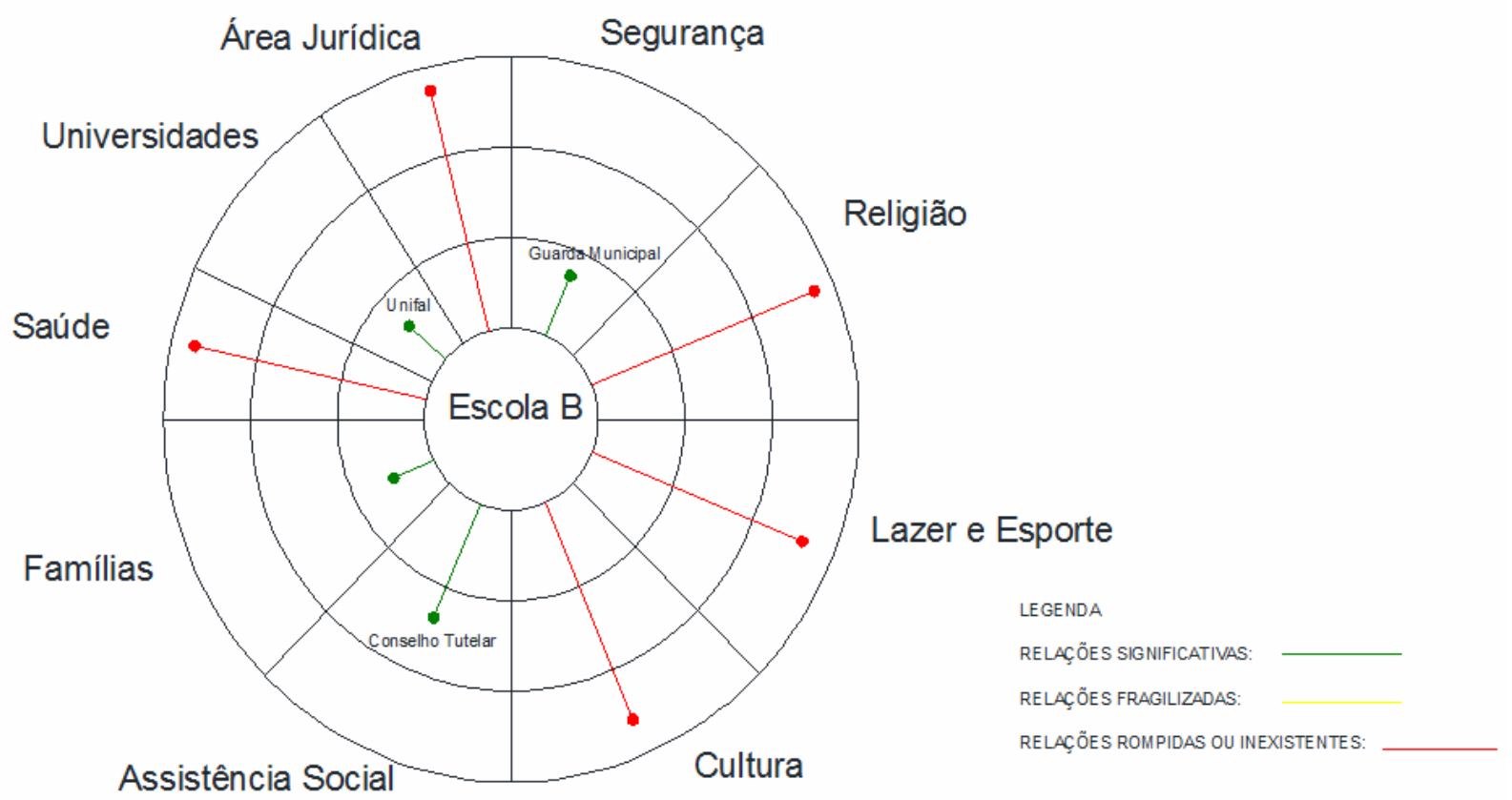

Figura 6 - Mapa Mínimo da Rede Social Externa da Escola B

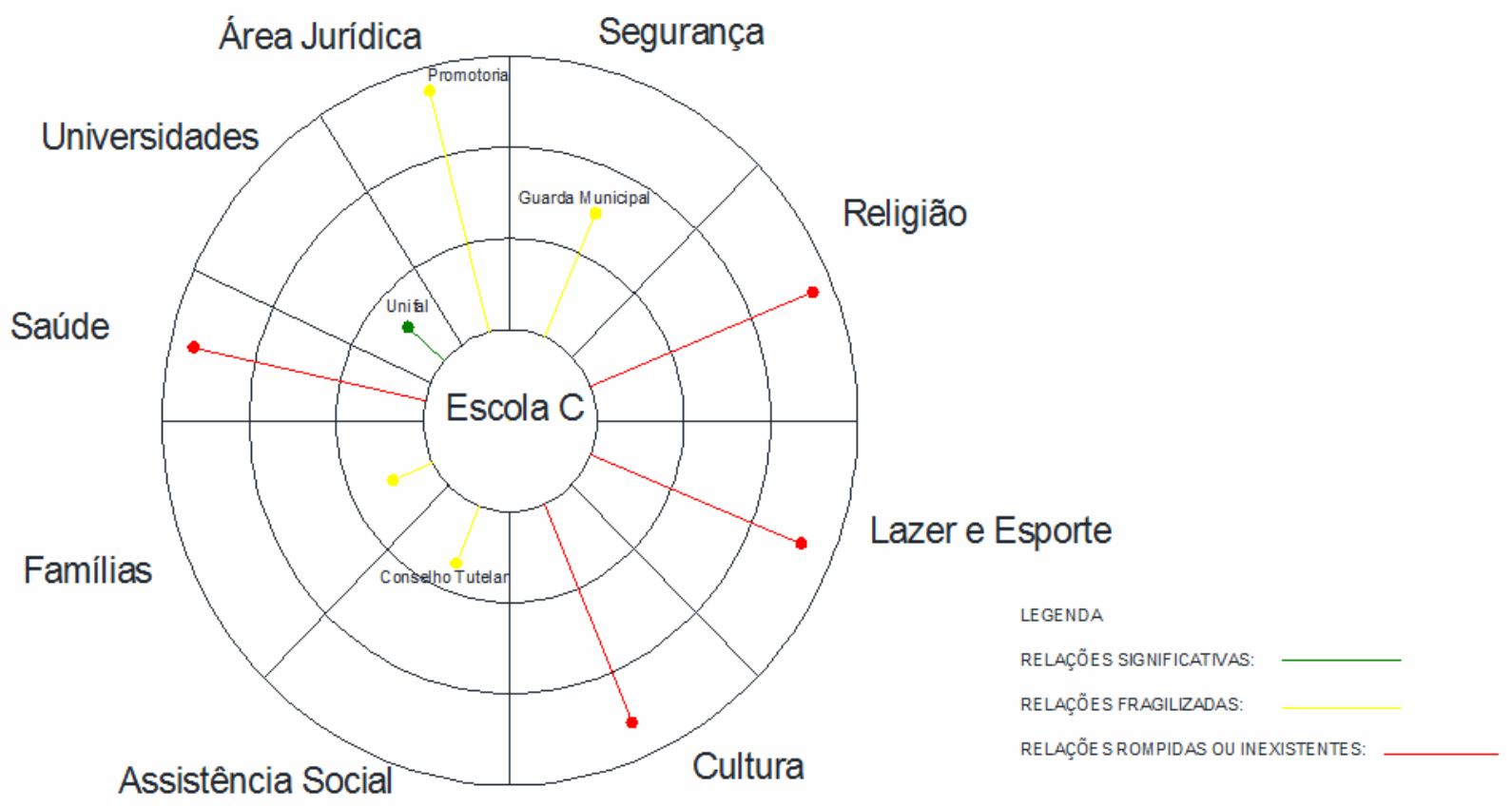

Figura 7 - Mapa Mínimo da Rede Social Externa da Escola C 


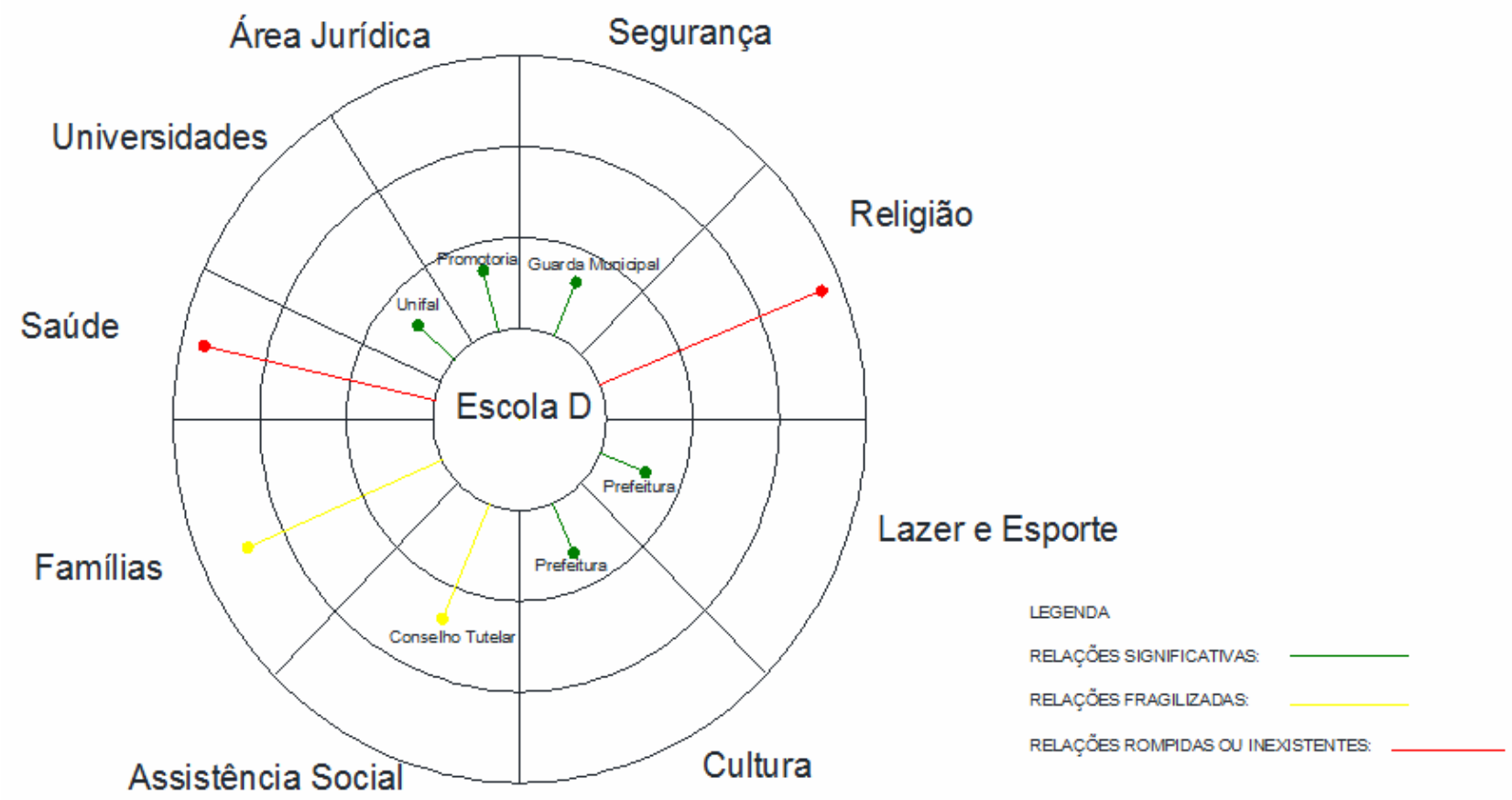

Figura 8 - Mapa Mínimo da Rede Social Externa da Escola D

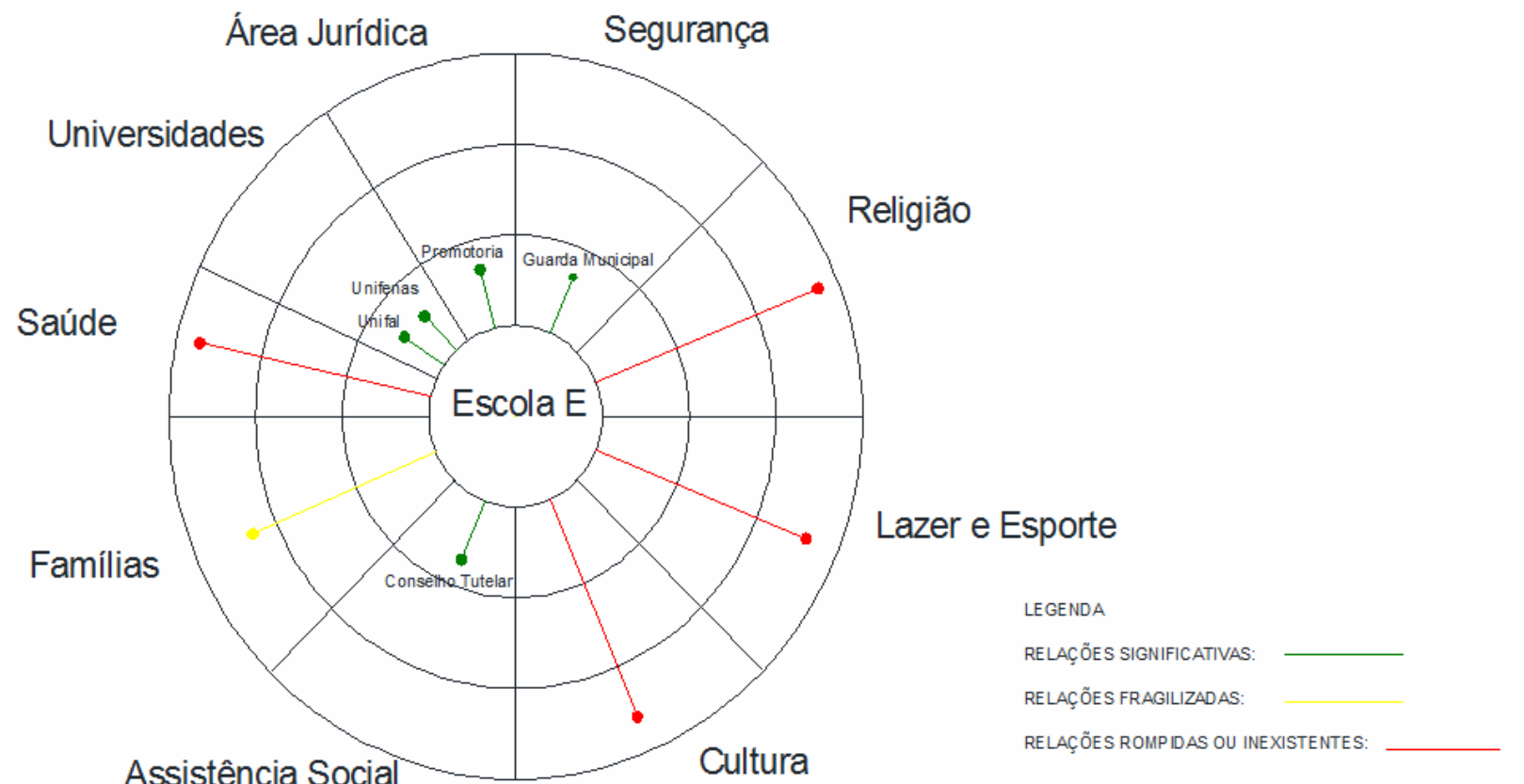

Figura 9 - Mapa Mínimo da Rede Social Externa da Escola E 


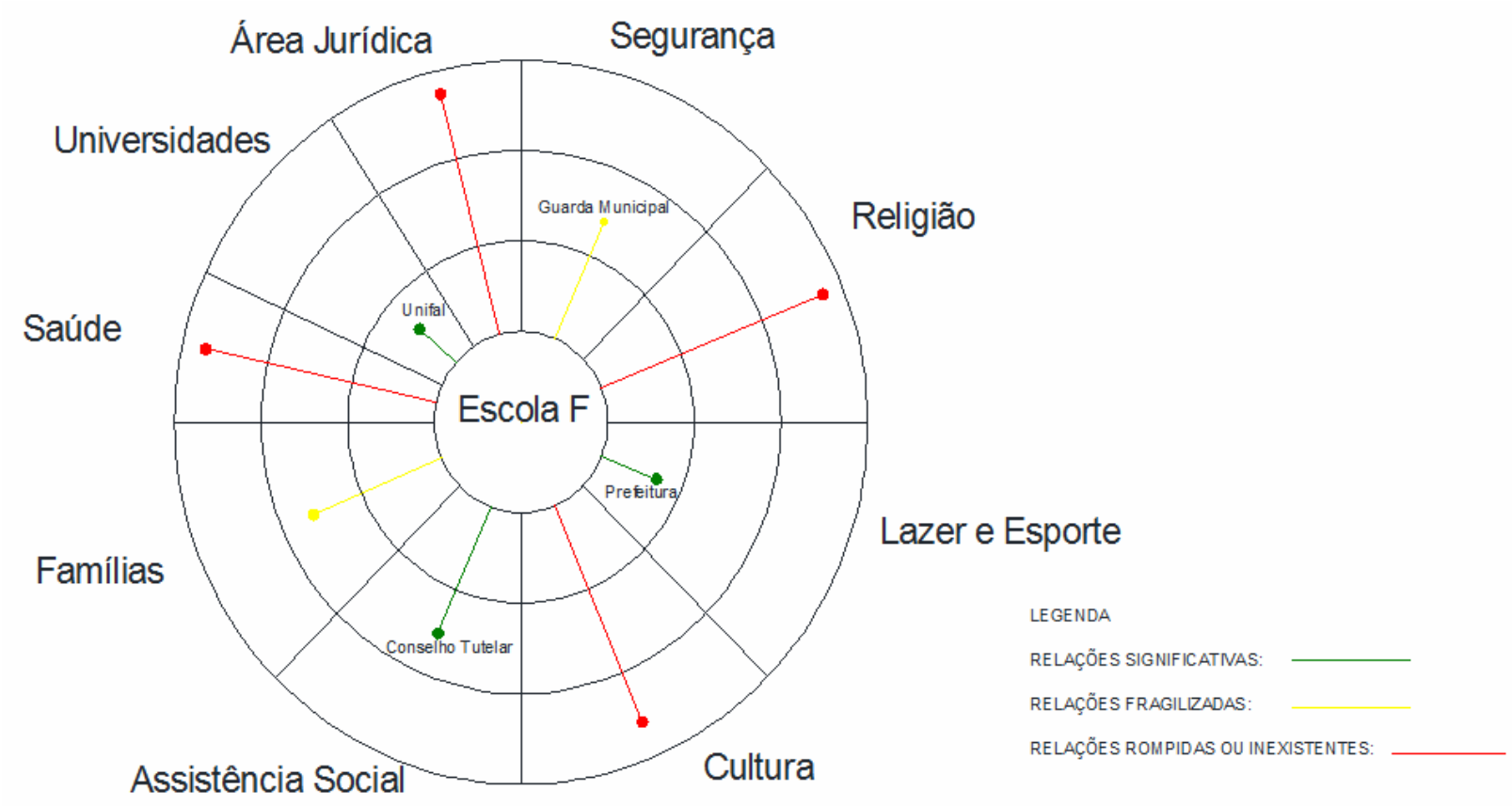

Figura 10 - Mapa Mínimo da Rede Social Externa da Escola F

Relembramos que, conforme as legendas, os Mapas representam vínculos significativos em verde, fragilizados em amarelo, rompidos ou inexistentes em vermelho.

Nos Mapas construídos pelos sujeitos, as redes apresentam, conforme Ude (2008), o tamanho reduzido, considerando o número de instituições que se vinculam às escolas nas ações em parceria para o enfrentamento das situações de violência sofrida ou praticada pelos estudantes. Segundo Sluzki (1997), uma rede reduzida não é satisfatória, tendo em vista que o indivíduo ou a instituição isolada é mais frágil e mais vulnerável.

Quanto à densidade, observamos o predomínio de vínculos rompidos ou inexistentes, sendo seguidos pelos traços verdes e, posteriormente, os amarelos, ressaltamos que nenhum Mapa apresentou todos os vínculos significativos. Conforme Ude (2008), para o enfrentamento efetivo dos casos de violência, preconiza-se o fortalecimento dos vínculos significativos.

Quanto à distribuição e composição que se relaciona ao número de instituições situadas em cada quadrante, não houve uma distribuição regular entre os quadrantes, o que dificulta a geração de fatores de proteção.

No que concerne à dispersão, que corresponde à distância geográfica entre as instituições, como citado anteriormente, cada escola localiza-se em pontos distintos da cidade. Contudo, consideramos que tal distância não constitui empecilho para o estabelecimento de 
vínculos porque, conforme Costas e Moran (2004), a sociedade moderna dispõe de meios de comunicação que podem significar um elo entre a escola e a comunidade, facilitando a interação com a sociedade como um todo.

Analisaremos cada quadrante separadamente com o propósito de estabelecermos uma melhor comparação entre as escolas bem como para a discussão dos dados obtidos.

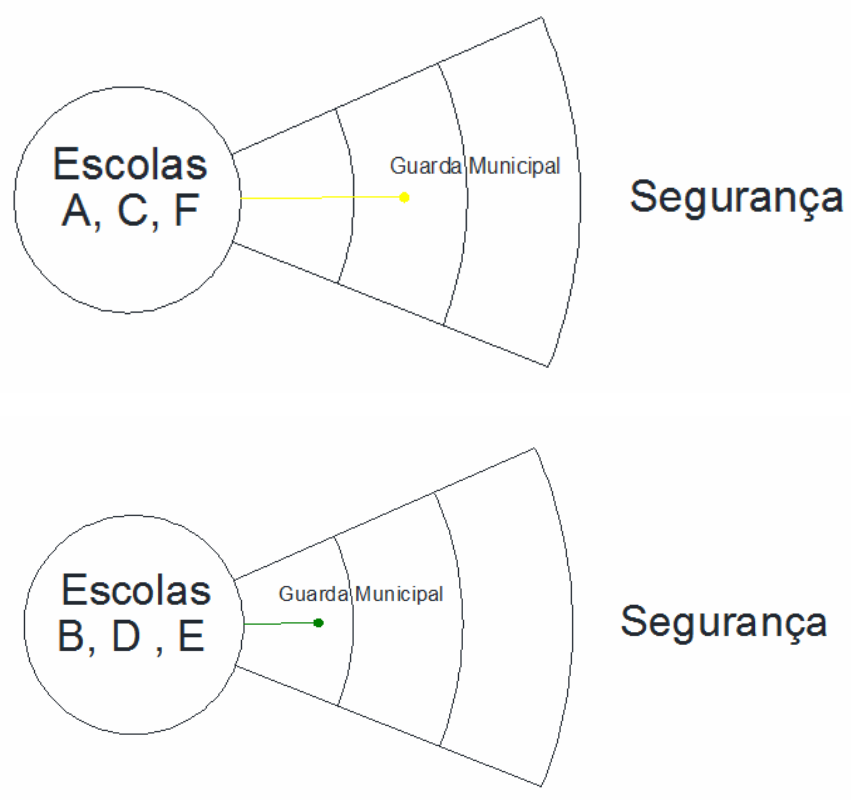

Figura 11 - Vínculo das escolas com a segurança

Como podemos perceber, a segurança das escolas é realizada pela Guarda Municipal, mais especificamente, pela Ronda Escolar. Contudo, a assistência não ocorre da mesma maneira em todas as escolas e isso pode se justificar pelo fato de apenas um Guarda Municipal realizar a cobertura de todas as escolas, atendendo prioritariamente aos chamados realizados pelas mesmas, os quais provavelmente são mais frequentes nas escolas B, D e E.

Liberal et al. (2005) recordam que a segurança deve favorecer o desenvolvimento humano, abrangendo todos os cidadãos no seu cotidiano: nas vias públicas, no trabalho, na escola, no lazer, no lar. Asseveram que o Estado continua a ser o principal responsável pela segurança. No entanto, a partir do momento em que os problemas de segurança aumentam em complexidade, novos atores passam a desempenhar um papel nesse domínio. Assim, outros setores da sociedade emergem como determinantes do estado de segurança. Entre eles, destacam-se a saúde e a educação. 


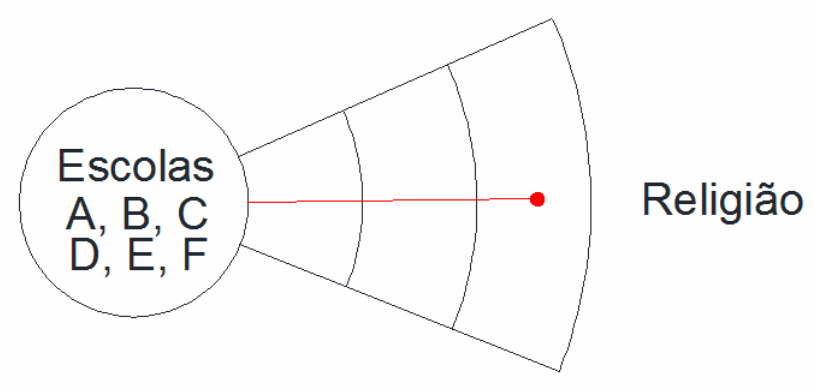

Figura 12 - Vínculo das escolas com a religião

A Constituição da República Federativa do Brasil (BRASIL, 1988), artigo 5, parágrafo VI, refere que a religião é direito individual. O artigo 33 da LDB (BRASIL, 1996e), fala do ensino religioso, sem mencionar o ensino médio, dizendo que o ensino religioso, de matrícula facultativa, constitui disciplina dos horários normais das escolas públicas de ensino fundamental, sendo oferecido, sem ônus para os cofres públicos, de acordo com as preferências manifestadas pelos alunos ou por seus responsáveis, em caráter:

I - confessional, de acordo com a opção religiosa do aluno ou do seu responsável, ministrado por professores ou orientadores religiosos preparados e credenciados pelas respectivas igrejas ou entidades religiosas; ou

II - interconfessional, resultante de acordo entre as diversas entidades religiosas, que se responsabilizarão pela elaboração do respectivo programa.

A LDB (BRASIL, 1996e) apresenta, portanto, no que se relaciona à religião, a proibição do proselitismo; a frequência optativa; a não-integralização da carga horária da disciplina nas 800 horas e a concessão do direito à audição pelo sistema de ensino de entidade civil representativa das igrejas.

A discussão em torno da religião envolve o respeito às diversas religiões existentes, sem posicionamentos que indiquem tentativas de conversão dos alunos. Dessa forma, quando trabalhada nas escolas de ensino fundamental, a disciplina de religião aborda temas gerais que se referem ao viver em sociedade, a valores éticos e de cidadania. Segundo os sujeitos, a disciplina não faz parte do currículo do ensino médio.

Ao abordamos a participação de grupos religiosos junto às escolas, todos os sujeitos, sem exceções, negaram essa participação, alegando que não seria permitido trabalhar religião junto aos alunos, mesmo que se tratasse de grupos da comunidade. 


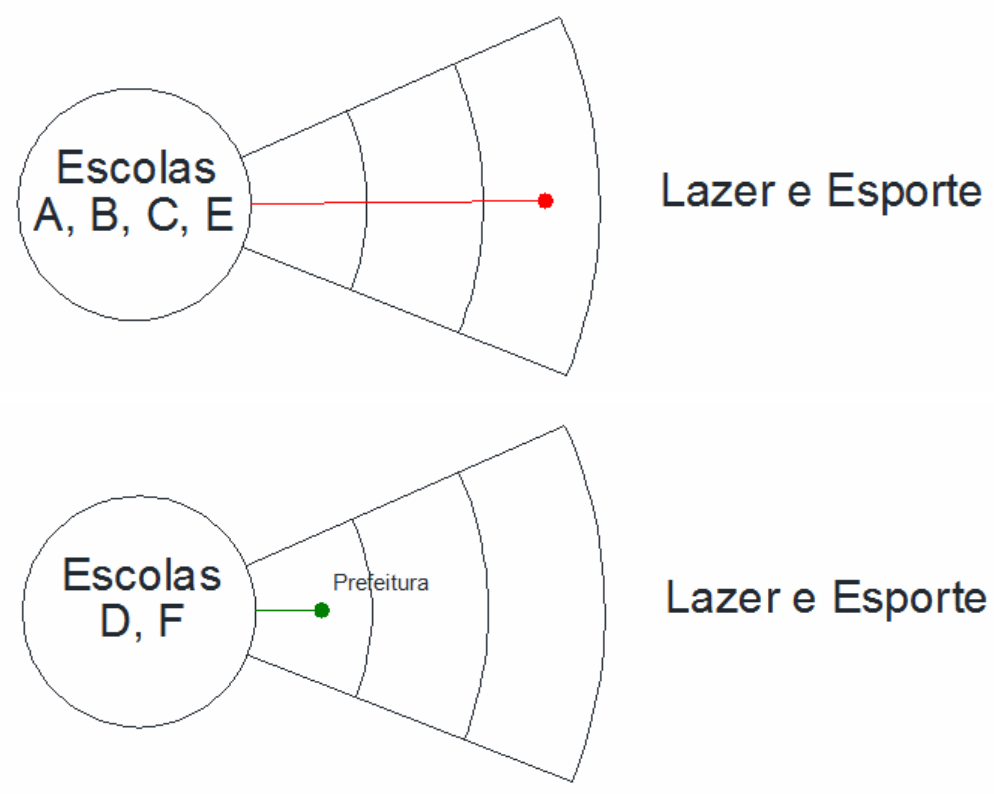

Figura 13 - Vínculo das escolas com o lazer e o esporte

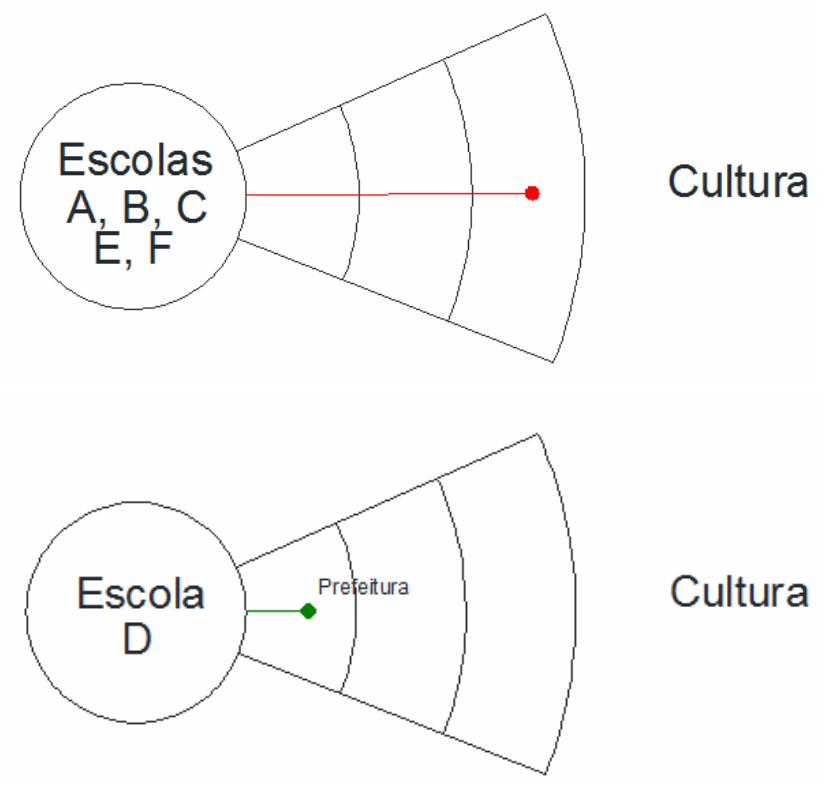

Figura 14 - Vínculo das escolas com a cultura

Lazer, esporte e cultura apresentam resultados semelhantes na comparação dos Mapas. Não existem grupos específicos que desenvolvam tais atividades nas escolas. Ao mencionar a Prefeitura, os sujeitos referem-se ao programa “Cidade Escola” já explicado anteriormente, o qual apresenta núcleos distribuídos por pontos diversos da cidade. Um desses núcleos encontra-se na escola $\mathrm{D}$, existindo outro próximo à escola $\mathrm{F}$. Cabe lembrar que os bairros em que se encontram essas duas escolas destacam-se por serem periféricos, com população carente e com situações de violência relacionadas a homicídios e a tráfico de drogas. É 
constante a referência desses três setores, lazer, esporte e cultura como propulsores de hábitos saudáveis, contrários à violência.

A prefeitura abraçou a escola (...) está implantando o projeto “Cidade Escola” que é um projeto fundamental, o aluno tem se envolvido, deu nove violões para ter aula de violão. (S 07)

Eric Dunning, célebre cientista social britânico, referência mundial no âmbito da sociologia dos esportes, em entrevista a Gastaldo (2008), refere que os esportes fazem parte de um "processo civilizatório" cuja principal função é a produção de excitação prazerosa e socialmente construtiva. Refere também que os esportes criam oportunidades de sociabilidade e movimento em uma variedade de formas complexas e controladas, como dança e ginástica, por exemplo, além de permitir a formação de identidades e pô-las à prova.

Gonçalves e Spósito (2002) analisam que a violência escolar no Brasil provém da situação de violência social que atinge os estabelecimentos, principalmente públicos, como também pode nascer no ambiente pedagógico e explicam que, a partir da década de 1980, administrações estaduais e municipais buscaram respostas variadas para o problema da violência escolar e que, na esfera federal, a tentativa de políticas de redução dessa violência partiu do Ministério da Justiça, talvez pelo aumento dos índices de violência envolvendo jovens com o crime organizado e com homicídios, seja como vítimas ou como protagonistas. Nas escolas públicas, a década de 1990 foi marcada não apenas por atos de vandalismo, como também por agressões interpessoais, verbais e ameaças, alcançando cidades médias e menos industrializadas do país. Em junho de 1999, houve a criação de uma comissão de especialistas encarregada de elaborar diretrizes para enfrentar a violência nas escolas, contando com a parceria de institutos de pesquisa e de organizações não governamentais.

Conforme os autores, o programa Paz nas Escolas pode ser considerado um resultado dessas parcerias, desenvolvido a partir do ano 2000 em 14 estados brasileiros, os quais assumiram uma dinâmica própria, de acordo com suas realidades. Dentre as principais atividades, estavam campanhas visando ao desarmamento da população; à formação e ao treinamento, integrando jovens e policiais no ensino de técnicas de mediação de conflitos e a ações de capacitação de educadores e policiais em direitos humanos e ética. O programa desenvolveu também ações de apoio à criação de grêmios estudantis, para tratar especialmente questões relativas à violência nas escolas.

Acreditava-se na necessidade de democratizar a escola por meio da participação de vários atores sociais, promovendo maior acesso dos setores populares à educação formal e melhoria da qualidade de ensino, eliminando-se os processos de evasão e repetência. 
Propunha-se a abertura das escolas para interações entre alunos e moradores dos bairros de periferia, mediante a ocupação dos espaços escolares nos fins de semana, para o desenvolvimento de atividades esportivas, culturais e de lazer.
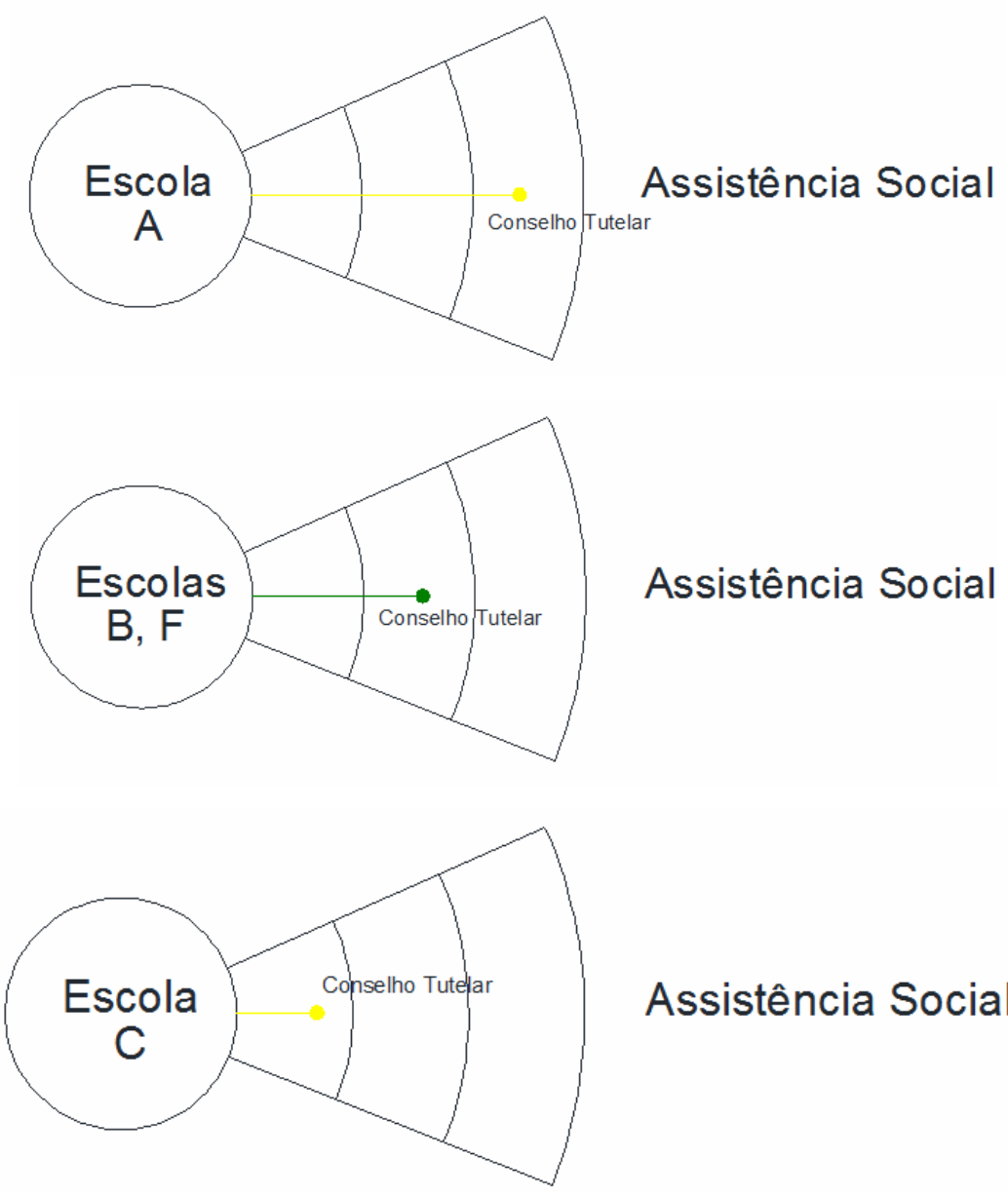

\section{Assistência Social}

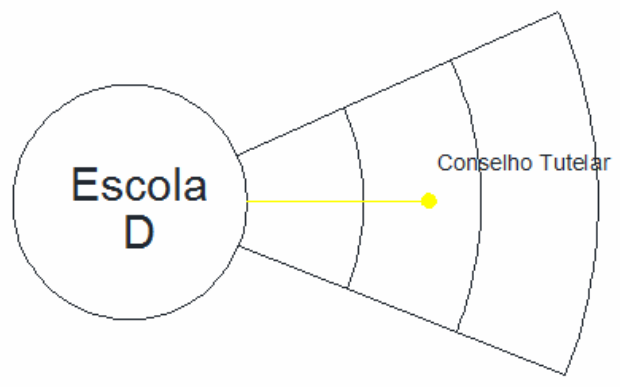

Assistência Social

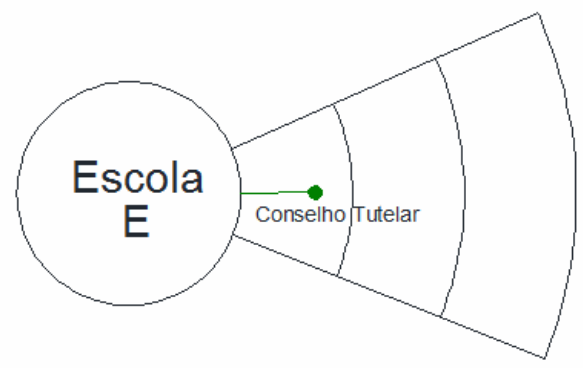

Assistência Social

Figura 15 - Vínculo das escolas com a assistência social 
O Conselho Tutelar de Alfenas está vinculado à Secretaria de Ação Social. Quando questionado o aspecto da assistência social, o Conselho apareceu em todos os Mapas apresentados com posicionamentos bem distintos, o que nos leva a concluir que o campo de atuação do Conselho não se encontra fortemente determinado, as ações são ocasionais e, geralmente, os alunos voltam a cometer violências.

O ECA (BRASIL, 1990c), no artigo 56, aponta as circunstâncias em que os dirigentes de estabelecimentos de ensino fundamental deverão entrar em contato com o Conselho Tutelar, mas não faz referência ao ensino médio. As ocasiões são as seguintes:

I - maus-tratos envolvendo seus alunos;

Il - reiteração de faltas injustificadas e de evasão escolar, esgotados os recursos escolares;

IIl - elevados níveis de repetência.

Conforme Souza, Teixeira e Silva (2003), o Conselho Tutelar é um órgão autônomo, que não integra o poder judiciário. Vincula-se à Prefeitura, mas a ela não se subordina. Sua fonte de autoridade pública é a lei do ECA e está sob a responsabilidade do Conselho Municipal dos Direitos da Criança e do Adolescente, o qual tem a função de controlar as políticas públicas municipais voltadas à criança e ao adolescente. Tais autoras discutem que o Conselho Tutelar é um órgão fundamental no processo de democratização dos serviços públicos prestados à comunidade jovem, seja por encaminhar as crianças e os adolescentes aos equipamentos pertinentes, seja por tentar adequar esses serviços às reais necessidades do público, diagnosticando quando não existem em número suficiente. Acrescentam que o Conselho não foi criado para fazer o que os outros órgãos de garantia de direitos, como a escola, não estão conseguindo ou estão negligenciando. Porém, dados os meandros e mecanismos das instituições brasileiras, isso vem ocorrendo. Em sua pesquisa, as autoras constataram que a escola encaminha ao Conselho Tutelar casos que seriam de sua responsabilidade, como por exemplo, resolver questões de indisciplina dos alunos.

O Conselho Tutelar, conforme aponta o próprio nome, tutela a criança ou o adolescente na falta ou na omissão dos pais e quando estes são os autores da violência. A escola deve recorrer inicialmente aos pais ou responsáveis e depois acionar o Conselho. Entendemos que isso tem sido feito por parte das escolas, mas observamos também, conforme as falas dos sujeitos, a desconfiança em relação ao Conselho Tutelar.

(...) falta uma assistência concreta do Conselho (...) porque a gente fica meio isolado (...). (S 03) 
(...) eu não sei te falar que limite o Conselho Tutelar tem sobre o aluno, ele é impossibilitado também de agir (...) eu não acredito muito no Conselho. (S 07)

Gonçalves e Spósito (2002) recordam, ainda, as situações em que os conselheiros exigem, por força do ECA, que os estabelecimentos de ensino recebam, nas salas de aula, alunos que cometeram atos infracionais, um procedimento rejeitado pelos corpos docente e discente de várias escolas, sob a alegação de falta de preparo dos professores para lidar com esse tipo de aluno. Os autores dizem que, ao rejeitarem a ação dos Conselhos Tutelares, as escolas põem em xeque o próprio ECA.

Essa também foi uma constatação do nosso estudo. Alguns sujeitos questionaram o ECA, alegando que o mesmo concedeu muitos direitos às crianças e aos adolescentes, mas se esqueceu de destacar os deveres. Dessa forma, crianças e adolescentes perderam a noção de limite, achando-se sempre em posição de acusação aos adultos ao seu redor, não apenas nas escolas, como também nas famílias. Receber por imposição os alunos que geralmente desencadeiam as violências, constitui uma das queixas dos sujeitos que apontaram a necessidade de ações mais efetivas por parte do Conselho, bem como um acompanhamento posterior desses adolescentes.

(...) o aluno tem que ficar na escola, só que esses alunos que dão problema não deveriam estar sem um atendimento, livre dentro de sala, porque aqui a gente não tem como. (S 02)

Eu acredito que o problema é por causa das leis de amparo ao menor (...) (S 02) 


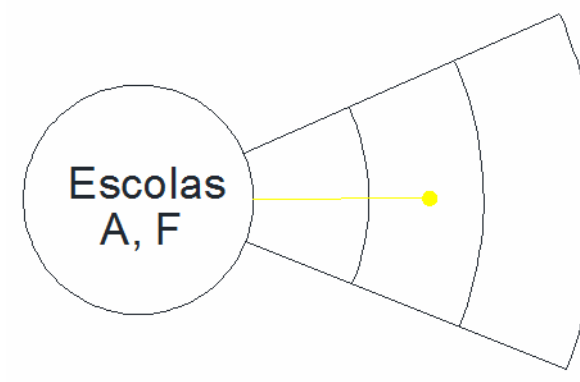

\section{Famílias}

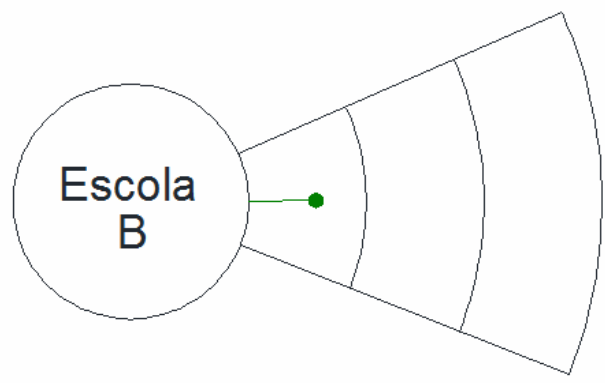

\section{Famílias}

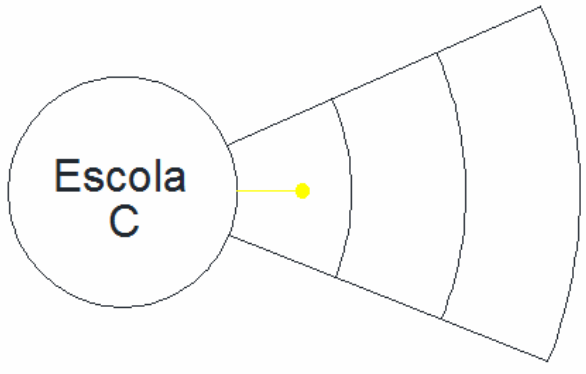

Famílias

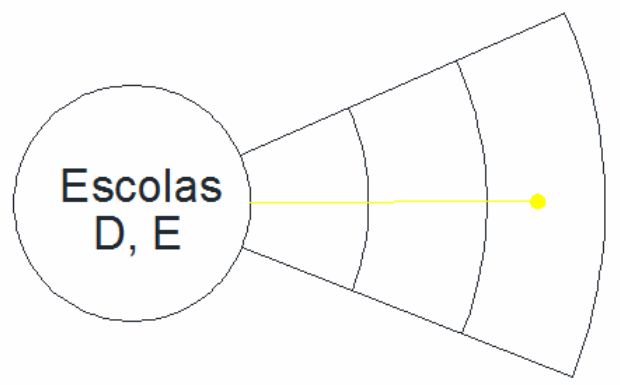

Famílias

Figura 16 - Vínculo das escolas com as famílias

Dentre todos os aspectos abordados, a família foi a instituição citada de forma veemente pelos sujeitos que ora manifestaram satisfação com o apoio familiar, ora referiram a necessidade primordial de os pais serem mais conscientes em relação aos filhos, participando mais ativamente da realidade escolar. Na maioria dos relatos, o vínculo da escola com a família é reconhecido como fragilizado; a família aparece apenas quando solicitada, sem manifestar interesse pelo rendimento diário dos filhos.

Sabemos que, desde o surgimento da escola como instituição social e sistema de educação formal, suas raízes encontram-se entrelaçadas às da família, numa relação que se 
constitui de maneira complexa e, por vezes, conflituosa.

Para a nossa discussão no que concerne à família, precisamos compreender, nos dias atuais, o que se entende por família, as conceituações que se aproximam dessa instituição em plenitude.

Anos atrás, poderíamos nos referir à família como uma estrutura composta pela figura masculina entendida como pai e a feminina no papel de mãe e os filhos. Tal como podemos ver, a Constituição Federal (BRASIL, 1988) estabelece os princípios fundamentais em relação à instituição familiar e reconhece como entidade familiar a união estável entre homem e mulher, ou a comunidade formada por quaisquer dois pais e seus descendentes. Assim, limitarmos nosso olhar e pensamento a essa antiga estrutura dificulta a compreensão da atual conjuntura que nos cerca.

De acordo com Trost (1995), a menor unidade de grupo é o casal, uma díade ou um par e, em seu entendimento, uma família se forma quando um casal se casa ou quando passa a viver na mesma casa, ou mesmo quando uma criança nasce e é criada por apenas um dos pais solteiros (pai ou mãe). Essa concepção privilegia a díade, enquanto unidade mínima da família, que deve ser constituída, pelo menos, por dois adultos ou por um adulto e uma criança. Infere-se dessa definição a inclusão dos casais que se constituíram legalmente, mediante casamento civil e/ou religioso, e também os que optaram por morar juntos, considerando, ainda, os casais heterossexuais e homossexuais.

Há quem considere o critério de intimidade e afetividade para se definir família. Dessa forma, o termo homoafetividade vem sendo cada vez mais utilizado com o propósito de mostrar que o afeto é a base formadora de qualquer casal, o qual possa se configurar em família.

Conforme Oliveira e Marinho-Araújo (2010), muitos são os modelos de família e ainda não é possível afirmar que exista uma definição de família que seja aceita e adotada consensualmente pelos estudiosos da área, pelas instituições governamentais e pela sociedade. Os diferentes tipos de família que têm sido descritos com maior frequência pelos pesquisadores da área são: família homossexual ou casais homossexuais; família extensa; famílias multigeracionais; família reconstituída ou recasada; família de mãe ou pai solteiro; casais que coabitam/vivem juntos (OLIVEIRA, MARINHO-ARAÚJO, 2010; STRATTON, 2003; TURNER, WEST, 1998; PETZOLD, 1996).

No que se diz respeito à educação, construiu-se a ideia de que a escola é responsável pela educação formal das crianças e dos adolescentes, enquanto a família o é pela educação informal. Nesse sentido, observamos esse complexo escola-família desempenhando papéis 
distintos e, ao mesmo tempo, complementares. Segundo Oliveira e Marinho-Araújo (2010), escola e família são instituições diferentes, que apresentam objetivos distintos; todavia, compartilham a importante tarefa de preparar crianças e adolescentes para a inserção na sociedade, a qual deve ter uma característica crítica, participativa e produtiva.

As mesmas autoras acrescentam que, analisando a história da relação que se estabeleceu entre escola e família ao longo do tempo, identifica-se que essa relação sempre esteve marcada por movimentos de culpabilização de uma das partes envolvidas, pela ausência de responsabilização compartilhada de todos os envolvidos e pela forte ênfase em situações-problema que ocorrem no contexto escolar.

É comum encontrarmos estudos cujos discursos apontam semelhanças em que as escolas culpabilizam as famílias pelo fracasso escolar dos alunos. Perez (2000) observa, ainda, que as atitudes dos pais, se contrárias às prescrições da escola, são rotuladas e interpretadas: “os pais não valorizam o estudo dos filhos, não fazem seu acompanhamento escolar, não se interessam”. Em nosso trabalho, essa ideia ressurge e é fortemente debatida pelos sujeitos, os quais afirmam que a família se mantém distanciada e só comparece quando solicitada.

(...) a gente nota o afastamento dessa família (...). (S 01)

A família vem bastante quando é chamada (...) eles não vêm procurar em outros momentos, saber como os meninos estão, eles esperam acontecer alguma coisa (...) (SO3)

A família pouco vem na escola, nós é que chamamos a família para a escola. (S 04)

(...) o pai não vem na escola, ele vem, na maioria das vezes, quando a gente chama por problemas, ele não vem de livre e espontânea vontade (...) (S 06)

A família ainda é muito distante (...) (S 07)

(...) a família sempre fica no meio, ela nunca está totalmente dentro da escola (...) (S 09) 
Devemos pensar os motivos pelos quais a família se mantém afastada da realidade escolar dos filhos. Ribeiro e Andrade (2006) observaram em seu estudo que o conhecimento propagado pela escola é visto e vivido pelos pais como superior ao seu, o que parece levá-los a pensar que não possuem os requisitos necessários para tornar seus questionamentos legítimos. Eles se posicionam, na maioria das vezes, de forma submissa e não questionadora, mesmo diante dos descompassos entre as exigências da escola e sua realidade, tecendo, nessas situações, justificativas para as suas dificuldades. A escola parece se relacionar com as famílias prioritariamente no sentido de uma exigência de complementaridade, com relação a suas expectativas e, a partir da atribuição de responsabilidade aos alunos, por suas próprias dificuldades. Não parece haver um movimento sistemático no sentido de se buscar compreender a realidade vivida pelos alunos e por suas famílias. Sigolo e Lollato (2001) acrescentam que os pais tendem a idealizar a escola, introjetando o que lá ouvem a respeito de si mesmos. Dessa forma, não lutam contra os estereótipos, sentindo-se comumente culpados pelas dificuldades dos filhos.

As reuniões com o propósito de promover o encontro entre pais e professores, de modo geral, são consideradas como pouco resolutivas tendo em vista que, segundo Oliveira (1999), essas reuniões ou as destinadas à entrega de boletins, em que os assuntos versam sobre comportamento e baixo rendimento escolar, acontecem de forma que as pessoas envolvidas apenas legitimam relações sociais existentes, havendo, de um lado, a cobrança dos professores e, do outro, o afastamento dos familiares. Para Perez (2000), as reuniões funcionam como mecanismo de controle, de avaliação, de comparação e de julgamento do desempenho dos pais e ocorrem primordialmente em função de problemas comportamentais.

Outro fator a ser analisado refere-se às transformações sociais e culturais pelas quais têm passado os arranjos familiares já que a família é a esfera responsável pela qualidade de vida de seus membros e nela são tomadas decisões relativas à moradia, à alimentação, à educação, à saúde, ao consumo em geral e, sobretudo, estão relacionadas com a participação na atividade econômica de seus membros. Dentre as mudanças observadas na estrutura familiar, podemos citar o menor número de matrimônios, o aumento das separações e atraso das uniões, conjuntamente com o novo papel da mulher na família e no trabalho, a qual teve importantes implicações nas relações de gênero. No interior das famílias, aumentou o número de mulheres que trabalham por remuneração, refletindo a consolidação da participação feminina no mercado de trabalho (LEONE; MAIA; BALTAR, 2010).

Para a contribuição das mulheres com a renda familiar, as mesmas passaram a conciliar o mercado de trabalho com os afazeres domésticos e com o cuidado destinado aos 
demais membros da família. Nessas condições, os relatos apontaram que os filhos têm sido encaminhados cada vez mais precocemente aos Centros de Educação Infantil e, nos anos seguintes, a participação dos pais nas atividades escolares se constrói de forma restrita, sendo transferida toda forma de responsabilização para a escola.

(...) hoje, pelo problema social e custo de vida, está difícil manter em casa um dos familiares (...) mais antigamente, mães cuidavam do lar e tinham uma relação estreita com o filho. Hoje, os pais precisam mandar os filhos para a escola, para a creche desde pequeno onde não tem essa união, essa relação estável de acontecimentos do cotidiano (...) desde pequeno os pais estão colocando na escola a obrigação de educar e se responsabilizar por seus atos (...) (S 06)

Os pais trabalham o dia todo, não têm tempo, sempre os filhos vêm para a escola, o pai já vai para o emprego, o tempo é muito restrito, nas reuniões vêm poucos pais. (S 09)

Por outro lado, a escola reconhece não ter condições de assumir tal função e, dessa forma, os papéis não são estabelecidos, gerando conflitos. Diante desses aspectos, como mencionado por Oliveira e Marinho-Araújo (2010), considera-se que a relação entre a família e a escola tem-se caracterizado por ser um fenômeno pouco harmonioso e insatisfatório, uma vez que as expectativas de cada instituição ou de cada ator envolvido não são atendidas e se mostram pouco favoráveis ao crescimento e ao desenvolvimento dos alunos, os quais se aborrecem com a relação em vez de tê-la como fonte de apoio e colaboração.

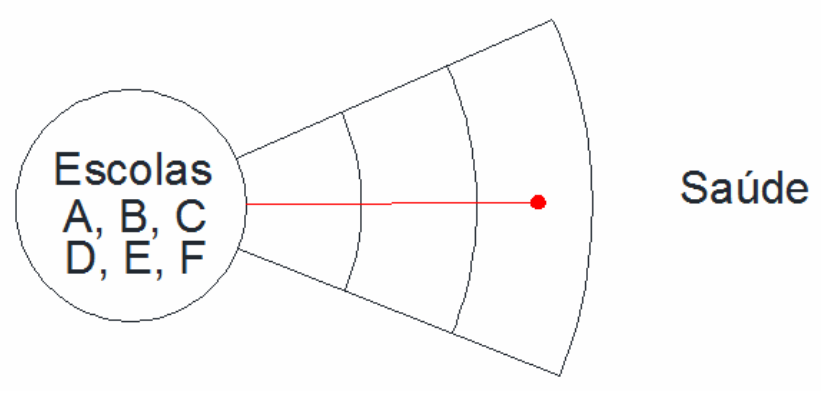

Figura 17 - Vínculo das escolas com a saúde 
Por mais que Alfenas apresente um número considerável de serviços de saúde, não existem trabalhos conjuntos com as escolas.

Santos et al. (2011) vislumbram a parceria viável entre a educação e a saúde somando esforços no intuito de encontrar subsídios para o enfrentamento da violência. Acrescentam que, para o êxito na elaboração de estratégias de educação em saúde, é necessário haver forte engajamento entre profissionais de saúde, comunidade e profissionais da educação, como expressão coletiva de suas intenções, alicerçados na realidade na qual se inserem, na perspectiva de desenvolver ações que possam prevenir e minimizar a violência nas escolas. Desse modo, os profissionais de saúde, ao se aproximarem do cotidiano das escolas, estarão contribuindo com a intersetorialidade, que deve ocorrer entre os setores de saúde e de educação, e estarão também delineando estratégias condizentes com a realidade encontrada, uma vez que as situações de violência existentes na escola são fatores que interferem negativamente no processo saúde-doença das pessoas envolvidas direta ou indiretamente com a problemática.

Conforme Freire (2000), os profissionais da área de saúde devem mobilizar a comunidade nos espaços intra e extraescolares, quanto a sua capacidade de propor soluções adequadas ao enfrentamento da violência que está se instalando no ambiente escolar, ou seja, levá-la a refletir sobre as implicações bioéticas que estão envolvidas nesse tipo de violência a partir da contextualização da problemática. Isso significa refletir com os atores envolvidos, de modo que impulsione um esforço permanente por meio do qual eles percebam, criticamente, como estão sendo no mundo.

Ferriani e Cano (1999) discutem a limitação dos profissionais de saúde quanto à assistência ao escolar, em que a atenção ainda se concentra na visão, na audição e na dentição dos alunos. Referem que os problemas de aprendizagem muitas vezes são tratados por meio de um modelo clínico tradicional, individual e biológico, isentando as responsabilidades do sistema educacional e da sociedade. Afirmam também que não basta o conhecimento técnicocientífico para que a teoria seja transformada em prática; existem outras questões relacionadas, como a necessidade de uma política transformadora que atinja todos os segmentos sociais para que se estabeleça uma política de saúde.

Para Galheigo (2008), recentemente, o setor saúde tem mudado o enfoque do plano curativo para o preventivo. Nesse aspecto, recordamos a já citada Política Nacional de Redução da Morbimortalidade por Acidentes e Violências e as recomendações do primeiro Relatório Mundial sobre Violência e Saúde que demandam ação conjunta e intersetorial. Dentre os pontos abordados por tais recomendações, está o desenvolvimento de programas para crianças e adolescentes do pré-natal à inclusão escolar. Enfatiza-se que a qualidade das 
políticas sociais de saúde, educação e assistência social devem ser preservadas a todo custo e que pessoas em desvantagem devem receber suporte especial, educacional e econômico.

Em 2006, a ONU lançou o relatório sobre a violência contra crianças, realizado por um especialista independente, abordando o fenômeno em ambientes variados como na família, nas escolas, em organizações sociais alternativas, em instituições de cumprimento de medida de privação de liberdade, em locais de trabalho e nas comunidades.

A Pesquisa Nacional de Saúde do Escolar (PeNSE), realizada em 2009 pelo Instituto Brasileiro de Geografia e Estatística (IBGE), em parceria com o Ministério da Saúde, veio contribuir para o diagnóstico de situações de violência vividas e percebidas por estudantes adolescentes, com o propósito de descrever as prevalências de percepção dos escolares sobre segurança no deslocamento para a escola e na escola, o envolvimento desse segmento com a violência física, com o uso de arma branca e com o uso de arma de fogo, bem como violência/agressões perpetradas por familiares. Pretende-se, assim, melhor compreender esse fenômeno e apoiar a tomada de decisão visando a sua prevenção (IBGE, 2009).
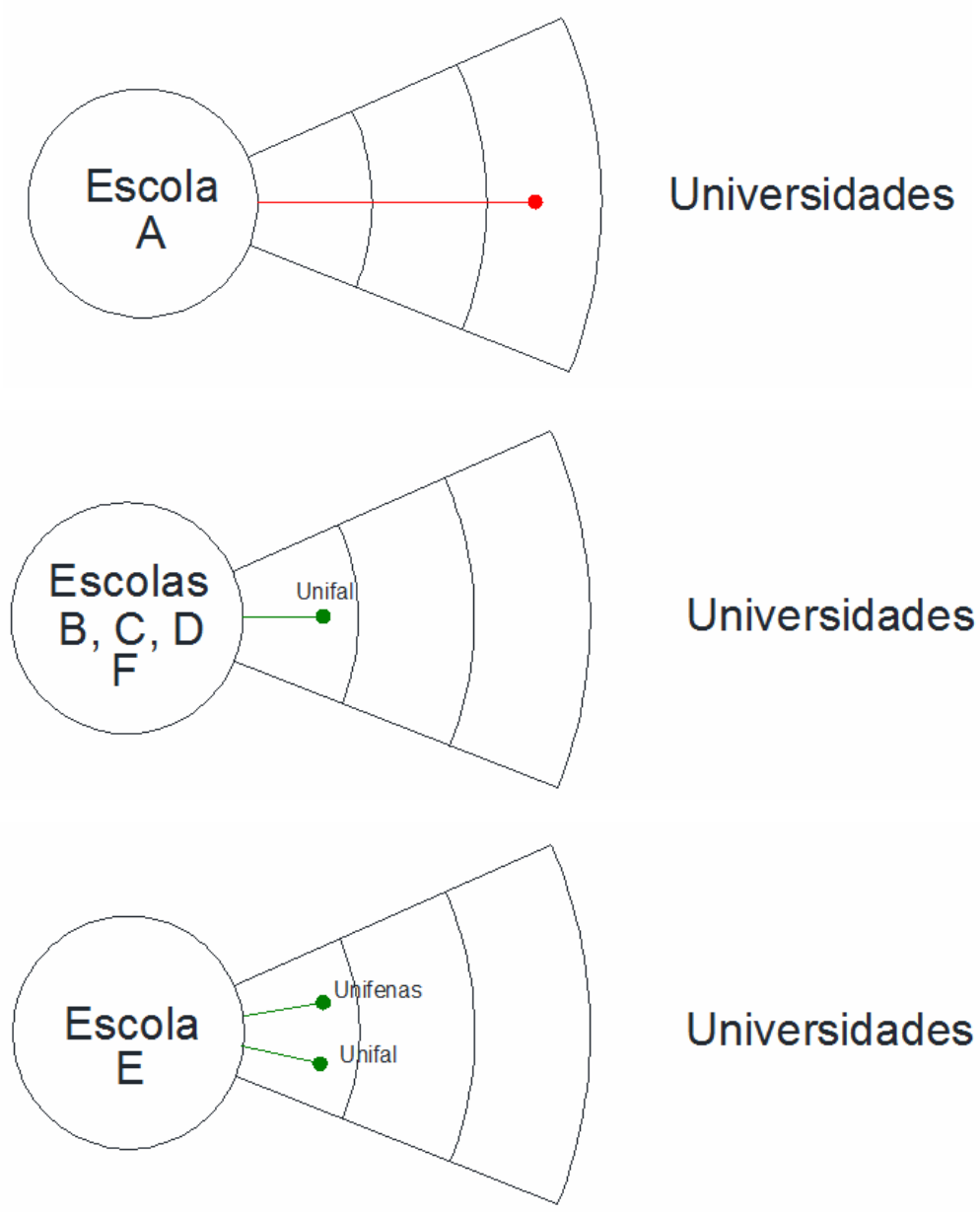

Figura 18 - Vínculo das escolas com as universidades 
Preconiza-se cada vez mais o desenvolvimento de ensino, pesquisa e extensão nas universidades. No que se refere à extensão, essa geralmente é voltada para as necessidades da comunidade e é comum a procura pelas escolas. As duas universidades existentes na cidade formam profissionais nos mais diversos campos de atuação, contudo é relevante a formação de profissionais da saúde. Dessa forma, são desenvolvidos nas escolas projetos na área da Enfermagem, da Odontologia, da Biologia, da Química, do Direito, da Agronomia, entre outros. Chama-nos a atenção a escola A, a qual não menciona a presença das universidades e também se mostrou como sendo a escola com o menor número de vínculos estabelecidos. Não há uma justificativa plausível para o fato, tendo em vista que os profissionais mostraram-se receptivos quanto a obterem ajuda e as características da escola assemelham-se às de outras analisadas.

Nas demais escolas, os sujeitos referiram que, quanto mais cedo os alunos tiverem conhecimento do universo existente nas universidades, maior será o interesse e o empenho para fazerem parte dessa realidade. É reconhecido o trabalho já desempenhado pelas universidades, mas as falas demonstram interesse de que o mesmo seja ampliado, pois as atividades são entendidas como forma de prevenção da violência e de suporte para as próprias escolas.

(...) para a prevenção da violência, nada mais é que as universidades abrirem as portas, vir até a escola e mostrar para os alunos a importância que têm (...). (S 01)

O trabalho que a universidade está fazendo é com parceria na área pedagógica, com todos os setores que a escola necessita (...). (S 04)

Mas se Deus quiser, logo vão vir mais alunos da universidade (...). (S 08)

(...) e para a prevenção, mais projetos, desenvolvendo mais projetos dentro da nossa escola. (S 09)

Zottis et al. (2008) fizeram uma análise da violência nos dias atuais em que o desenvolvimento sustentável é profundamente debatido, segundo o conceito do Relatório Brundtland, também chamado Nosso Futuro Comum, Our Common Future, que é o 
documento final da Comissão Mundial sobre Meio Ambiente e Desenvolvimento, promovida pela ONU, nos anos 1980 e chefiada pela então primeira-ministra da Noruega, Gro Harlen Brundtland. Esse conceito é apresentado a seguir.

\begin{abstract}
O desenvolvimento que procura satisfazer as necessidades da geração atual, sem comprometer a capacidade das gerações futuras de satisfazerem as suas próprias necessidades, significa possibilitar que as pessoas, agora e no futuro, atinjam um nível satisfatório de desenvolvimento social, econômico, de realização humana e cultural, fazendo, ao mesmo tempo, um uso razoável dos recursos da terra e preservando as espécies e os habitats naturais.
\end{abstract}

Os autores asseveram que não basta falar de desenvolvimento sustentável, é preciso considerar uma sociedade sustentável em que é promovida uma Cultura de Paz por meio de valores e de atitudes que reforçam a não violência. Nesse aspecto, ressaltam o papel social das universidades, as quais devem integrar ensino, pesquisa e extensão, observando os problemas da comunidade tais como a pobreza, as desigualdades sociais e a violência, além de criarem modelos, experiências práticas e concretas que sirvam de molde para políticas públicas.

Os mesmos autores apresentam alguns esforços práticos do meio universitário voltados para o aspecto da violência, os quais são o Laboratório de Estudos da Criança (LACRI) do Instituto de Psicologia da USP; o Núcleo de Atenção à Criança Vítima de Violência da Universidade Federal do Rio de Janeiro (UFRJ); o Centro Latino-Americano de Estudos de Violência e Saúde da Escola Nacional de Saúde Pública Sergio Arouca da Fundação Oswaldo Cruz (ENSP-Fiocruz); o Grupo de Assistência, Pesquisa e Educação na Área da Saúde e da Família (GAPEFAM) da Universidade Federal de Santa Catarina (UFSC) e o serviço da Universidade Federal do Rio Grande do Sul (UFRGS) que, por meio do projeto Proteger, estuda o comportamento violento e age para diminuir efetivamente a violência.

Cabe ressaltar Francischini e Souza Neto (2007), os quais apresentam em seu estudo que, diante do quadro de violência a que estão submetidas crianças e adolescentes no Brasil, o Ministério da Educação propôs às Pró-Reitorias de Extensão das instituições públicas federais de ensino superior uma parceria na estruturação e implementação do projeto Escola que Protege, com o propósito de mobilizar e convocar a rede de ensino no sentido de sensibilizar também as escolas e as demais entidades. Educadores foram convocados a participar do Sistema de Garantia dos Direitos da Criança e do Adolescente, a partir do conhecimento de vários aspectos a esse sistema relacionados e das principais modalidades de violência presentes no cotidiano de grande parcela da população infanto-juvenil. O projeto Escola que Protege, portanto, soma-se às demais iniciativas nessa área e reflete uma das recomendações do Relatório da ONU (2006), que afirma a necessidade de capacitação de todas as pessoas que 
trabalham com e para crianças e adolescentes visando a contribuir para eliminar todas as formas de violência contra eles.

O Relatório acrescenta que os estados devem investir em programas educacionais e de capacitação sistemáticos para profissionais e leigos que trabalham com ou para crianças, para adolescentes e para suas famílias com vistas a prevenir, detectar e responder à violência. Códigos de conduta e normas claras para práticas devem ser formuladas e implementadas, incorporando a proibição e a rejeição de todas as formas de violência.

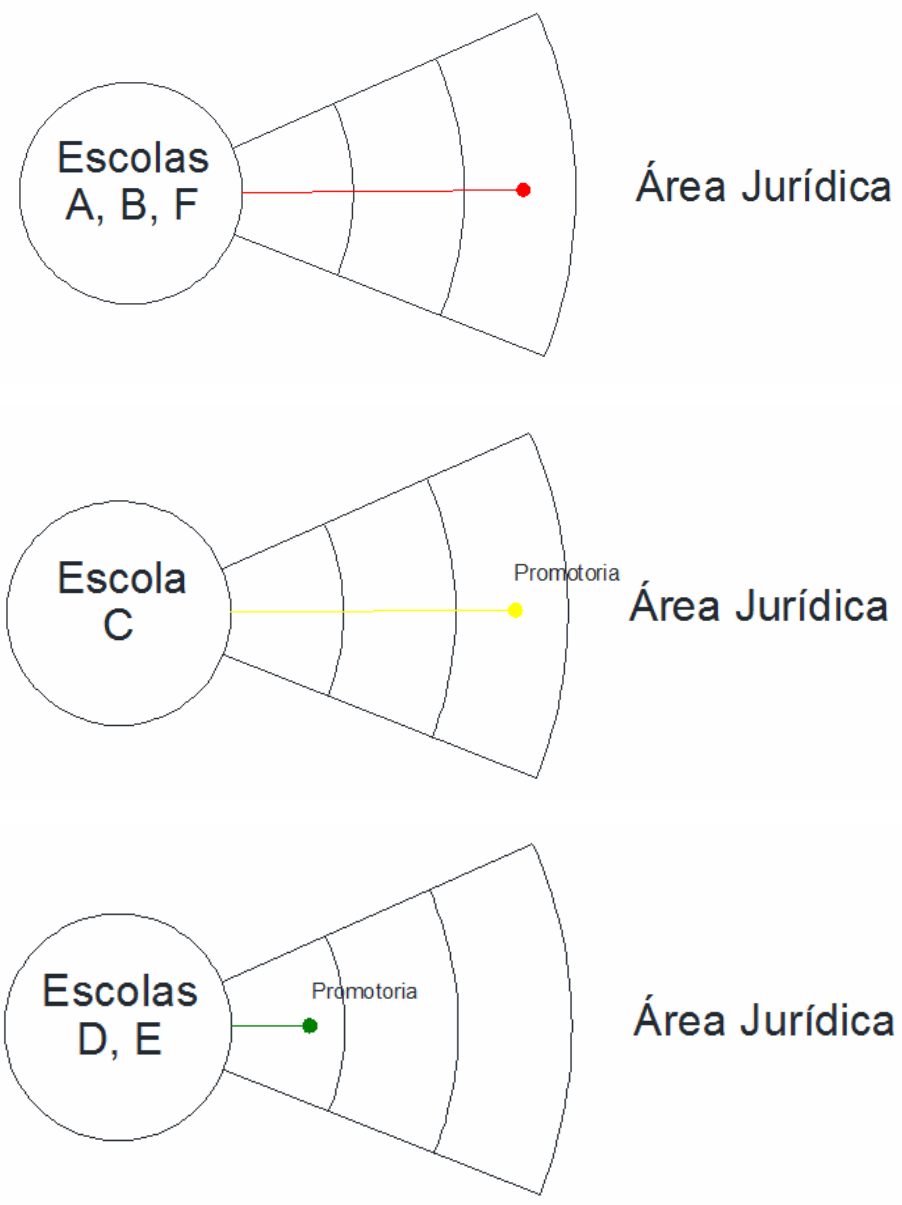

Figura 19 - Vínculo das escolas com a área jurídica

Ao utilizarmos o termo área jurídica, podemos incluir o Conselho de Defesa da Criança e do Adolescente, o Juizado, a Defensoria, a Promotoria Pública, ou seja, todas as instâncias judiciárias presentes nas redes. No entanto, o que pudemos observar foi somente a atuação da Promotoria Pública em metade das escolas, apenas em casos extremos. Para Silva (2001), os promotores são membros do Ministério Público, tendo como uma de suas atribuições a defesa dos interesses que afetam indivíduos, grupos da sociedade e contingentes populacionais relacionados 
ao patrimônio público, ao meio ambiente, ao consumidor, aos idosos e às crianças. Por meio do atendimento ao público, uma antiga atribuição do Ministério Público, os promotores orientam, informam, fazem encaminhamentos, recebem denúncias e reclamações dos diversos setores da sociedade. Há casos que são levados aos órgãos estatais de assistência judiciária, outros dão origem a investigações e a processos propostos pelo Ministério Público.

Como no caso do Conselho Tutelar, os sujeitos não reconhecem a efetividade da Promotoria Pública e voltaram a dizer que a mesma também impõe que os alunos sejam aceitos em sala de aula, mas não oferecem acompanhamentos com o propósito de prevenir a reincidência de casos, as ações tornam-se paliativas porque, como afirma Priotto (2009, p. 6069), “o entendimento de respeito ao outro não se aprende sob pressão”.

(...) a Promotoria, ela manda o menino de volta, ela deveria mandar alguém vir aqui ajudar, uma Assistente Social e não só mandar o menino de volta (...). (S 03)

Como a escola chegou ao ponto de ou fazia ou fechava, então viu a necessidade de recorrer ao promotor (...). (S 07)

Silva (2001) diferencia promotor de gabinete de promotor de fatos, definindo o promotor de gabinete como aquele que, embora utilize procedimentos extrajudiciais no exercício de suas funções, dá relevância à proposição de medidas judiciais e ao exame e ao parecer dos processos judiciais dos quais está encarregado. O promotor de fatos dá tanta ou mais importância ao uso de procedimentos extrajudiciais, mobilizando recursos da comunidade, acionando organismos governamentais e não governamentais e agindo como articulador político. Segundo a mesma autora, o combate ao trabalho infantil e às irregularidades no transporte escolar, a implantação de conselhos municipais da criança, a instalação de creches e iniciativas visando a programas de reforço escolar nas escolas e combate à evasão escolar são alguns dos projetos existentes na área dos direitos da criança. $\mathrm{O}$ poder de requisitar documentos e informações das escolas, de delegacias de ensino e de secretarias permite que o promotor reúna dados sobre os índices de evasão em determinada região ou cidade. A partir daí, ele pode iniciar um trabalho com escolas e com pais de alunos, requerendo a presença dos últimos em reuniões ou audiências.

Após a observação geral das redes existentes a partir das escolas, constatamos um número reduzido de vínculos e a fragilidade significativa entre aqueles existentes. $\mathrm{O}$ 
fenômeno da violência é reconhecido por todos como complexo e, sem a atuação conjunta e organizada dos diversos setores sociais, em que cada instituição compreende o seu papel, o enfrentamento dessa temática torna-se ainda mais longínquo.

A escola nem sempre constitui um local para abrigar, proteger e socializar as pessoas. Muitas vezes, a violência praticada de várias maneiras, envolvendo crianças e adolescentes, começa dentro desse ambiente e se torna necessária a mobilização de uma rede de proteção integral em que a escola se destaca como possuidora de responsabilidade social ampliada (BRASIL, 2008b).

A interação entre escola, família e comunidade constitui fator relevante para que as habilidades sociais sejam desenvolvidas na infância e na adolescência (RICHARDSON et al., 2009). Escolas que estimulam o senso de vínculo dos alunos estão associadas a um número reduzido de problemas comportamentais e de atos de violência, de melhorias na saúde mental, de redução do abuso de substâncias por adolescentes e dos comportamentos sexuais de risco (JONSON-REID, 2009).

Amparo et al. (2008) citam entre os fatores de proteção para o indivíduo a importância de um bom relacionamento com professores, amigos e demais pessoas dentro do ambiente escolar, fazendo o estudante sentir-se seguro e querido.

Os fatores relacionados a reações violentas, quer sejam derivados de atitudes e comportamentos ou de condições sociais, econômicas, políticas e culturais mais amplas, podem ser modificados. Com frequência, tem sido comprovado que esforços coletivos provenientes de setores diversos, como saúde, educação, cultura, esportes, serviço social, justiça e políticas, são necessários para a solução do problema, e, coletivamente, têm o potencial de produzir reduções relevantes da violência (DAHLBERG; KRUG, 2006).

Segundo Rêgo e Rocha (2009), a educação é, e sempre foi, a esperança de transformação e de desenvolvimento do ser humano, ao ser exercida com liberdade, favorecendo a solidariedade, o viver comunitário, com amor e respeito entre pessoas. 


\section{CONSIDERAÇÕES FINAIS}

Em resposta ao objetivo deste estudo, identificamos e analisamos as redes sociais em torno das escolas de ensino médio pertencentes à rede estadual de Alfenas-MG para o enfrentamento dos casos de violência escolar.

Atendendo aos pressupostos, constatamos que a violência constitui um fenômeno pouco compreendido pelos profissionais que atuam nas escolas, os quais não se sentem devidamente preparados diante de suas manifestações. Também encontramos lacunas e fragilidades nas redes ao redor das instituições escolares.

Os relatos apontaram Conselho Tutelar, Promotoria Pública, Guarda Municipal, Prefeitura e universidades como apoio para o enfrentamento da violência escolar. Identificamos que a família recorre à escola, mas, ao mesmo tempo, a escola busca a atuação da família e das demais instituições citadas, transferindo a elas, muitas vezes, casos que não precisariam de suas intervenções. Como resultado final, cada setor faz o que está ao seu alcance, dentro do seu conhecimento e de suas possibilidades, sem a certeza de que esteja fazendo o melhor.

O Núcleo Temático “A Escola e a Violência” apresentou a necessidade de compreendermos o contexto no qual as escolas estão inseridas, bem como as transformações sofridas pelas mesmas com o passar dos anos que resultaram no acesso de uma grande diversidade de alunos.

A identificação desses alunos com o espaço físico escolar mostrou-se essencial para a conservação do ambiente. Entendemos que os danos causados aos patrimônios escolares geram gastos que comprometem a obtenção de outros materiais que poderiam ser úteis aos próprios discentes.

No que se refere às manifestações de violência, os sujeitos, por desconhecerem a amplitude do fenômeno, limitando-se geralmente aos danos físicos, deixam de perceber determinados atos como violentos, apontam com frequência as discussões entre colegas e até mesmo envolvendo professores, mas as consideram justificáveis por diversas razões, como o fato de os alunos serem adolescentes, fase em que os conflitos e as divergências de ideias são vistos como naturais. Considerando que a escola é o espaço do conhecimento e de transmissão dos valores considerados fundamentais para o viver em sociedade, reforçamos que os diferentes tipos de violência não devem ser banalizados.

No Núcleo Temático “O Enfrentamento da Violência Escolar”, observamos que os sujeitos veem os alunos como desrespeitosos, sem consideração pelo espaço escolar e por 
seus agentes. As propostas para o enfrentamento da violência escolar vão desde a intervenção nas violências cotidianas vividas pelas escolas, a conscientização dos profissionais, dos familiares e da comunidade, até as políticas públicas educacionais, destacando-se a relevância da atuação em rede. Nas escolas estudadas, as ações têm início internamente e, nas circunstâncias em que extrapolam o controle escolar, instituições externas são solicitadas.

O Subtema “Ações Internas” explica a trajetória assumida pelas escolas em que todas as situações entendidas como violentas exigem a atuação do supervisor no sentido de advertir o estudante de forma verbal ou escrita. Quando o diálogo não atinge o resultado almejado, o Conselho Tutelar, a Guarda Municipal e a Promotoria Pública são contatados, lembrando que os pais ou responsáveis são sempre comunicados.

Os sujeitos referiram satisfação no relacionamento entre todos os funcionários, existindo liberdade de atuação e apoio nos momentos que exigem trabalho conjunto. Uma das dificuldades vivenciadas refere-se à formação dos educadores que não os prepara adequadamente para agirem mediante situações de violência, fato que os leva a se manifestarem intuitivamente, sem conhecimentos específicos. Nesse sentido, lembramos a necessidade de educação continuada para esses profissionais.

Os Mapas elaborados pelos sujeitos e expostos no Subtema “A Atuação em Rede” nos permitiram analisar o tamanho reduzido das redes, considerando o número de instituições que se vinculam às escolas. A respeito da densidade, observamos o predomínio de vínculos rompidos ou inexistentes, sendo seguidos pelos significativos e, posteriormente, pelos fragilizados. Quanto à distribuição e à composição de instituições em cada quadrante, não houve uma distribuição regular, dificultando a geração de fatores de proteção. No tocante à dispersão, à distância geográfica entre as instituições, consideramos que tal distância não constitui empecilho para o estabelecimento de vínculos devido aos modernos meios de comunicação disponíveis atualmente que permitem a interação das escolas com todos os setores sociais necessários.

Quando abordados sobre a segurança, os sujeitos mencionaram a Guarda Municipal que, por meio da Ronda Escolar, atende aos chamados das escolas. Contudo, a existência de apenas um Guarda para tal tarefa impede que a assistência se realize da mesma forma para todas as escolas.

Não existem grupos religiosos trabalhando junto às escolas, até mesmo a disciplina de religião não faz parte do currículo do ensino médio. Esse fato envolve o respeito às diversas religiões existentes, sem posicionamentos que indiquem tentativas de conversão dos alunos.

Nos setores referentes ao lazer, ao esporte e à cultura, não existem grupos específicos que desenvolvam tais atividades nas escolas. A Prefeitura foi citada devido ao programa 
“Cidade Escola” que apresenta núcleos distribuídos por pontos diversos da cidade, tendo como umas das atividades mencionadas, as aulas de violão. $\mathrm{O}$ aprimoramento de tais setores se faz essencial tendo em vista que correspodem a práticas saudáveis, contrárias à violência.

O Conselho Tutelar vincula-se à Secretaria de Ação Social e constitui o apoio no setor da assistência social. Todavia seu campo de atuação gera dúvidas nos sujeitos uma vez que suas ações são ocasionais e as escolas se sentem obrigadas, por imposição do ECA, a receber nas salas de aula os alunos que cometeram atos infracionais, o que se transforma num fator gerador de tensão já que tais alunos frequentemente tornam a praticar violências.

As famílias foram fortemente lembradas pelos supervisores tendo em vista que os modelos familiares têm sofrido grandes transformações não sendo possível assumir uma definição de família consensual entre estudiosos, instituições governamentais e sociedade. É comum encontrarmos estudos em que as escolas culpabilizam as famílias pelo fracasso escolar dos filhos. Em nosso trabalho, essa ideia foi apresentada, sendo frequente a afirmação de que as famílias se mantêm afastadas da realidade escolar. A fragilidade na estrutura familiar, com números significativos de separações e a inserção da mulher no mercado de trabalho, seriam algumas das razões para as famílias se manterem distantes, delegando às escolas responsabilidades que não caberiam a essas instituições.

Alfenas apresenta um número considerável de serviços de saúde, mas não existem parcerias com as escolas. A atuação conjunta dos setores saúde e educação é vislumbrada para o enfrentamento da violência, lembrando que já não cabe ao setor saúde apenas o enfoque no plano curativo, mas também um amplo olhar para a prevenção.

As universidades desempenham inúmeros projetos de extensão nas escolas, os quais são acolhidos e desejados pelas mesmas. Essa parceria é considerada fundamental para que os alunos almejem uma profissão. Como a cidade conta com duas universidades e cursos em diversas áreas, várias temáticas são trabalhadas nas escolas, podemos citar a assistência Odontológica, de Enfermagem, reforços de Química, de Biologia, orientações sobre Direito e Agronomia. Os vínculos estabelecidos com as instituições de ensino superior podem favorecer a capacitação dos profissionais e dos leigos que trabalham com crianças e adolescentes com o propósito de prevenir, detectar e responder à violência.

Na área jurídica, observamos a atuação da Promotoria Pública que é acessada em casos extremos que fogem ao controle das escolas. Os promotores, dentre outras atribuições, orientam, informam, fazem encaminhamentos, recebem denúncias e reclamações. Todavia, assim como ocorre com o Conselho Tutelar, sua efetividade é questionada pelos sujeitos que novamente se sentem obrigados a acolher em sala de aula os alunos envolvidos em situações 
de violência, sem que esses recebam um acompanhamento posterior.

Constatamos que a escola nem sempre consegue abrigar, proteger e disseminar o conhecimento entre seus alunos. Em muitas situações, a violência tem início nesse ambiente, sendo necessária a atuação em rede porque a escola sozinha se torna frágil e fica impossibilitada de enfrentar esse fenômeno.

Recomendamos a interação entre escola, pais e comunidade. A atuação conjunta dos diversos setores mencionados neste trabalho pode promover a proteção das escolas, de seus alunos e profissionais, reduzindo as manifestações de violência.

Diante da complexidade do tema abordado, sabemos que este estudo favoreceu a compreensão do problema de pesquisa, contudo novos questionamentos surgirão para instigar outros pesquisadores a buscar novos conhecimentos e alternativas com a finalidade de minimizar a violência escolar e promover uma Cultura de Paz nas escolas. 


\section{REFERÊNCIAS}

ABRAMOVAY, M. Escolas inovadoras: um retrato de alternativas. In: Desafios e alternativas; violências nas escolas. Anais... Seminário "Violência nas Escolas". Brasília, DF: UNESCO, 2003.

ALMEIDA, A.; LISBOA, C.; CAURCEL, M. J. Por qué ocurren los malos tratos entre iguales? Explicaciones causales de adolescentes portugueses y brasileños. Revista Interamericana de Psicologia, Austin, v. 41, n. 2, p. 107-118, 2007.

AMPARO, D. M. et al. Adolescentes e jovens em situação de risco psicossocial: redes de apoio social e fatores pessoais de proteção. Estudos de Psicologia, Natal, v. 13, n. 2, p. 165174, 2008.

ANDRADE, G. R. B.; VAITSMAN, J. Apoio social e redes: conectando solidariedade e saúde. Ciência \& Saúde Coletiva, Rio de Janeiro, v. 7, n. 4, p. 925-934, 2002.

BRASIL. Artigo 2, Lei no 8.069, de 1990. Estatuto da criança e do adolescente. Brasília, DF, 1990a.

BRASIL. Artigo 33, Lei no 9.394, de 1996. Diretrizes e bases da educação nacional. Brasília, DF, 1996e.

BRASIL. Artigo 35, Lei no 9.394, de 1996. Diretrizes e bases da educação nacional. Brasília, DF, 1996d.

BRASIL. Artigo 37, Lei nº 9.394, de 1996. Diretrizes e bases da educação nacional. Brasília, DF, 1996b.

BRASIL. Artigo 53, Lei nº 8.069, de 1990. Estatuto da criança e do adolescente. Brasília, DF, 1990b.

BRASIL. Artigo 56, Lei nº 8.069, de 1990. Estatuto da criança e do adolescente. Brasília, DF, 1990c.

BRASIL. Artigo 64, Lei nº 9.394, de 1996. Diretrizes e bases da educação nacional. Brasília, DF, 1996c.

BRASIL. Ministério da Educação. Secretaria de Educação Continuada. Alfabetização e Diversidade. Escola que protege: enfrentando a violência contra crianças e adolescentes. 2. ed. Brasília, DF, 2008b. 
BRASIL. Ministério da Saúde. Fundação Nacional de Saúde. Resolução nº 196, de 10 de outubro de 1996 - sobre pesquisas envolvendo seres humanos. Informe Epidemiológico do SUS. Brasília, DF, v. 5, n. 2, p. 13-41, abr./jun. 1996a. Suplemento 3.

BRASIL. Ministério da Saúde. Impacto da violência na saúde das crianças e adolescentes. Brasília, DF, 2008a.

BRASIL. Ministério da Saúde. Portaria MS/GM n. ${ }^{0} 737$ de 16/05/01. Política nacional de redução da morbimortalidade por acidentes e violências. Diário Oficial da União, Brasília, DF, n. 96, Seção 1E, 18 maio 2001.

BRASIL. Secretaria de Educação Fundamental. Parâmetros curriculares nacionais: terceiro e quarto ciclos. Apresentação dos temas transversais. Brasília, DF: MEC-SEF, 1998.

BRASIL. Ministério da Educação. Secretaria Especial dos Direitos Humanos. Guia escolar: métodos da identificação de sinais de abuso e exploração sexual de crianças e adolescentes. Brasília, DF, 2004.

BRASIL. Senado Federal. Constituição da República Federativa do Brasil. Brasília, DF: Senado Federal, 1988.

BRITO, R.; KOLLER, S. H. Desenvolvimento humano e redes de apoio social e afetivo. In: CARVALHO, A. M. O mundo social da criança: natureza e cultura em ação. São Paulo: Casa do Psicólogo, 1999. p. 115-129.

CAMACHO, L. M. Y. Violência e indisciplina nas práticas escolares de adolescentes: um estudo das realidades de duas escolas semelhantes e diferentes entre si. 2000. 276 f. Tese (Doutorado) - Universidade de São Paulo, São Paulo, 2000.

CERVO, A. L.; BERVIAN, P. A. Metodologia científica. 5. ed. São Paulo: Prentice Hall, 2002.

CHARLOT, B. A violência na escola: como os sociólogos franceses abordam essa questão. Sociologias, Porto Alegre, v. 4, n. 8, p. 432-443, jul./dez. 2002.

CHRISPINO, A. Gestão do conflito escolar: da classificação dos conflitos aos modelos de mediação. Ensaio: Avaliação e Políticas Públicas em Educação, Rio de Janeiro, v. 15, n. 54, p. 11-28, jan./mar. 2007.

CHRISPINO, A.; DUSI, M. L. H. M. Uma proposta de modelagem de política pública para a redução da violência escolar e promoção da Cultura da Paz. Ensaio: Avaliação e Políticas Públicas em Educação, Rio de Janeiro, v. 16, n. 61, p. 597-624, out./dez. 2008. 
COHEN, C.; GOBBETTI, G. J. Bioética da vida cotidiana. Revista Brasileira para o Progresso da Ciência, São Paulo, v. 56, n. 4, p. 47-49, 2004.

COSTAS, J. M. M.; MORAN, J. M. A contribuição das tecnologias para uma educação inovadora. Contrapontos (UNIVALI), Itajaí, v. 4, n. 2, p. 347-356, 2004.

DABAS, E. N. Red de redes: las prácticas de la intervención en redes sociales. Buenos Aires: Paidós, 1998.

DAHLBERG, L. L.; KRUG, E. G. Violência: um problema global de saúde pública. Ciência \& Saúde Coletiva, Rio de Janeiro, v. 11, p. 1163-1178, 2006. Suplemento.

DEMO, P. Desafios modernos da educação. 12. ed. Petrópolis: Vozes, 2002.

DESSEN, M. A.; BRAZ, M. P. Rede social de apoio durante transições familiares decorrentes do nascimento de filhos. Psicologia: Teoria e Pesquisa, Brasília, v. 16, n. 3, p. 221-231, 2000.

EYNG, A. M. et al. Políticas e gestão educacional: escolarização e violência. In: CONGRESSO IBERO-AMERICANO SOBRE VIOLÊNCIA NAS ESCOLAS, 2., 2005, Belém. Anais... Belém: UNAMA, 2005. p. 01-14.

FERRIANI, M. G. C.; CANO, M. A. T. O programa de saúde escolar no município de Ribeirão Preto. Revista Latino-Americana de Enfermagem, Ribeirão Preto, v. 7, n. 4, p. 2938, out. 1999.

FARIA FILHO, L. M.; VIDAL, D. G. Os tempos e os espaços escolares no processo de institucionalização da escola primária no Brasil. Revista Brasileira de Educação, Rio de Janeiro, n. 14, p. 19-35, maio/ago. 2000.

FRANCISCHINI, R.; SOUZA NETO, M. O. Enfrentamento à violência contra crianças e adolescentes: projeto Escola que Protege. Revista do Departamento de Psicologia - UFF, Niterói, v. 19, n. 1, p. 243-252, jan./jun. 2007.

FREIRE, P. Educação como prática da liberdade. 24. ed. Rio de Janeiro: Paz e Terra, 2000.

GALHEIGO, S. M. Apontamentos para se pensar ações de prevenção à violência pelo setor saúde. Saúde e Sociedade, São Paulo, v. 17, n. 3, p. 181-189, 2008.

GASTALDO, É. Esporte, violência e civilização: uma entrevista com Eric Dunning. Horizontes Antropológicos, Porto Alegre, v. 14, n. 30, p. 223-231, jul./dez. 2008. 
GIL, A. C. Como elaborar projetos de pesquisa. 4. ed. São Paulo: Atlas, 2002.

GONÇALVES, L. A. O.; SPÓSITO, M. P. Iniciativas públicas de redução da violência escolar no Brasil. Cadernos de Pesquisa, São Paulo, n. 115, p. 101-138, mar. 2002.

GRANGE, L. et al. Educação, violência e bioética sob a ótica do estudante secundário brasileiro. Âmbito Jurídico, Rio Grande, n. 32, p. 1-6, ago. 2006. Ano 9.

HABIGZANG, L. F. et al. Fatores de risco e de proteção na rede de atendimento a crianças e adolescentes vítimas de violência sexual. Psicologia: Reflexão e Crítica, Porto Alegre, v. 19, n. 3, p. 379-386, 2006.

INSTITUTO BRASILEIRO DE GEOGRAFIA E ESTATÍSTICA - IBGE. Pesquisa nacional de saúde do escolar - PeNSE. Rio de Janeiro: IBGE, 2009.

INSTITUTO BRASILEIRO DE GEOGRAFIA E ESTATÍSTICA - IBGE. Censo demográfico. 2010. Disponível em: <http://www.ibge.gov.br>. Acesso em: 21 jan. 2011.

JONSON-REID, M. An ounce of prevention: connections to school. Children \& Schools, Washington, DC, v. 31, n. 2, p. 67-69, Apr. 2009.

LEONE, E. T.; MAIA, A. G.; BALTAR, P. E. Mudanças na composição das famílias e impactos sobre a redução da pobreza no Brasil. Economia e Sociedade, Campinas, v. 19, n. 1, p. 59-77, abr. 2010.

LIBERAL, E. F. et al. Escola segura. Jornal de Pediatria, Rio de Janeiro, v. 81, n. 5, p. 155163, 2005. Suplemento.

LOPES NETO, A. A. Bullying: comportamento agressivo entre estudantes. Jornal de Pediatria, Rio de Janeiro, v. 81, n. 5, p. 164-172, 2005.

MACEDO, R. M. A.; BOMFIM, M. C. A. Violências na escola. Revista Diálogo Educacional, Curitiba, v. 9, n. 28, p. 605-618, 2009.

MARTINS, P. H. As redes sociais, o sistema da dádiva e o paradoxo sociológico. Redes Sociais e Saúde. Recife: UFPE, 2008.

MELMAN, J. et al. Tecendo redes de paz. Saúde e Sociedade, São Paulo, v. 18, p. 66-72, 2009. Suplemento 1.

MENDES, A. C. B. A escola e a articulação em redes: um olhar situado nas fronteiras intersetoriais e dos intersaberes. In: SANTOS, G. L.; JUNIOR, L. C. F.; UDE, W. Escola, violência e redes sociais. Belo Horizonte: FAE/UFMG, 2009. p. 94-110. 
MINAS GERAIS. Secretaria de Estado da Educação de Minas Gerais. Guia do especialista em educação básica. Belo Horizonte, 2008.

MINAYO, M. C. S. Abordagem antropológica para avaliação de políticas sociais. Revista de Saúde Pública, São Paulo, v. 25, n. 3, p. 233-238, 1991.

MINAYO, M. C. S. O desafio do conhecimento: pesquisa qualitativa em saúde. 12. ed. São Paulo: Hucitec, 2010.

MINAYO, M. C. S. Trabalho de campo: contexto de observação, interação e descoberta. In: MINAYO, M. C. S.; DESLANDES, S. F.; GOMES, R. Pesquisa social: teoria, método e criatividade. Petrópolis: Vozes, 2007. p. 61-77.

MINAYO, M. C. S. Violência: um problema para a saúde dos brasileiros. In: BRASIL. Ministério da Saúde, Secretaria de Vigilância em Saúde. Impacto da violência na saúde dos brasileiros. Brasília, DF, 2005. p. 09-41.

MIRANDA, M. I. F. Violências nas escolas sob o olhar da saúde - das indisciplinas e incivilidades às morbimortalidades por causas externas. 2004. $243 \mathrm{f}$. Tese (Doutorado) Universidade de São Paulo, Ribeirão Preto, 2004.

NJAINE, K.; MINAYO, M. C. S. Violência na escola: identificando pistas para a prevenção. Interface - Comunicação, Saúde, Educação, Botucatu, v. 7, n. 13, p. 119-134, 2003.

OLIVEIRA, C. B. E.; MARINHO-ARAÚJO, C. M. A relação família-escola: intersecções e desafios. Estudos de Psicologia, Campinas, v. 27, n. 1, p. 99-108, jan./mar. 2010.

OLIVEIRA, J. E. C. As ações das escolas, através de seus gestores, no processo de enfrentamento da violência escolar. 2009. 244 f. Tese (Doutorado) - Universidade de São Paulo, Ribeirão Preto, 2009.

OLIVEIRA, M. C. Família, escola e participação. Educação, Porto Alegre, n. 37, p. 151-176, 1999. Ano 22.

OLIVEIRA, S. A. “Redes”: mapeando seus usos no campo das ciências sociais. Mimeo, 2000a.

OLIVEIRA, S. L. Tratado de metodologia científica: projetos de pesquisa, TGI, TCC, monografias, dissertações e teses. 2. ed. São Paulo: Pioneira, 2000b.

ORGANIZAÇÃO DAS NAÇÕES UNIDAS - ONU. Relatório sobre o estudo das Nações Unidas sobre a violência contra crianças. 2006. Disponível em:

$<$ http://www.unviolencestudy.org > . Acesso em: 18 jul. 2011. 
ORGANIZAÇÃO DAS NAÇÕES UNIDAS - ONU. Resolución A/RES/53/243, aprobada por la Asamblea General el 6 de octubre de 1999. Declaración y programa de acción sobre una Cultura de Paz. New York, 1999.

ORGANIZAÇÃO PANAMERICANA DA SAÚDE - OPAS. Violência y salud: resolución $\mathrm{n}^{\circ}$ XIX. Washington, 1994.

PEDRO, I. C. S.; ROCHA, S. M. M.; NASCIMENTO, L. C. Apoio e rede social em enfermagem familiar: revendo conceitos. Revista Latino-Americana de Enfermagem, Ribeirão Preto, v. 16, n. 2, p. 324-327, 2008.

PEREZ, M. C. A. Família e escola na educação à criança: análise das representações presentes em relatos de alunos, pais e professores de uma escola pública de ensino fundamental. 2000. 594 f. Dissertação (Mestrado) - Universidade de São Paulo, Ribeirão Preto, 2000.

PETZOLD, M. The psychological definition of the family. In: CUSINATO, M. (Org.). Research on family resources and needs across the world. Milano-Itália: LEDEdizioni Universitarie, 1996. p. 25-44.

PIRES, A. L. D.; MIYAZAKI, M. C. O. S. Maus-tratos contra crianças e adolescentes: revisão da literatura para profissionais da saúde. Arquivos de Ciências da Saúde, São José do Rio Preto, v. 12, n. 1, p. 42-49, jan./mar. 2005.

PIZARRO, H. C.; JIMÉNEZ, M. I. Maltrato entre iguales en la escuela costarricense. Revista Educación, Porto Rico, v. 31, n. 1, p. 135-144, 2007.

PRIOTTO, E. P. Características da violência escolar envolvendo adolescentes. In: EDUCERE-CONGRESSO NACIONAL DE EDUCAÇÃO-PUCPR-PRAXIS, 6., 2006, Curitiba. Anais... Curitiba: PUCPR, 2006. p. 16-28.

PRIOTTO, E. P.; BONETI, L. W. Violência escolar: na escola, da escola e contra a escola. Revista Diálogo Educacional (PUCPR), Curitiba, v. 9, p. 161-179, 2009.

PRIOTTO, E. P. Práticas educativas de prevenção da violência escolar. In: CONGRESSO NACIONAL DE EDUCAÇÃO-EDUCERE, 9.; SUL BRASILEIRO DE PSICOPEDAGOGIA, 3., 2009, Curitiba. Anais... Curitiba: Editora Champagnat, 2009. p. 6057-6069.

RÊGO, C. C. A. B.; ROCHA, N. M. F. Avaliando a educação emocional: subsídios para um repensar da sala de aula. Ensaio: Avaliação e Políticas Públicas em Educação, Rio de Janeiro, v. 17, n. 62, p. 135-152, jan./mar. 2009. 
RIBEIRO, D. F.; ANDRADE, A. S. A assimetria na relação entre família e escola pública. Paidéia, Ribeirão Preto, v. 16, n. 35, p. 385-394, 2006.

RICHARDSON, R. C. et al. Character education: lessons for teaching social and emotional competence. Children \& Schools, Washington, DC, v. 31, n. 2, p. 71-78, Apr. 2009.

RISTUM, M.; BASTOS, A. C. S. Violência urbana: uma análise de conceitos de professores do ensino fundamental. Ciência e Saúde Coletiva, Rio de Janeiro, v. 9, n. 1, p. 225-239, 2004.

SANTOS, F. P. A. et al. Estratégias de enfrentamento dos dilemas bioéticos gerados pela violência na escola. Physis Revista de Saúde Coletiva, Rio de Janeiro, v. 21, n. 1, p. 267281, 2011.

SEBASTIÃO, J.; ALVES, M. G.; CAMPOS, J. Violência na escola: das políticas aos quotidianos. Sociologia, Problemas e Práticas, Lisboa, n. 41, p. 37-62, 2003.

SEIXAS, S. R. Violência escolar: metodologias de identificação dos alunos agressores e/ou vítimas. Análise Psicológica, Lisboa, v. 23, n. 2, p. 97-110, abr. 2005.

SIGOLO, S. R. L.; LOLLATO, S. O. Aproximações entre escola e família: um desafio para educadores. In: CHAKUR, C. R. S. L. (Org.). Problemas da educação sob o olhar da psicologia. São Paulo: Cultura Acadêmica, 2001. p. 37-65.

SILVA, C. A. Promotores de justiça e novas formas de atuação em defesa de interesses sociais e coletivos. Revista Brasileira de Ciências Sociais, São Paulo, v. 16, n. 45, p. 127144, fev. 2001.

SILVA, J. M. A. P.; SALLES, L. M. F. A violência na escola: abordagens teóricas e propostas de prevenção. Educar em Revista, Curitiba, p. 217-232, 2010. Número especial 2.

SIQUEIRA, A. C.; BETTS, M. K.; DELL'AGLIO, D. D. A rede de apoio social e afetivo de adolescentes institucionalizados no sul do Brasil. Revista Interamericana de Psicologia, Austin, v. 40, n. 2, p. 149-158, 2006.

SISTO, F. F. Aceitação-rejeição para estudar e agressividade na escola. Psicologia em Estudo, Maringá, v. 10, n. 1, p. 117-125, 2005.

SLUZKI, C. E. A rede social na prática sistêmica. São Paulo: Casa do Psicólogo, 1997.

SOUZA, M. H. N.; SOUZA, I. E. O.; TOCANTINS, F. R. A utilização do referencial metodológico de rede social na assistência de Enfermagem a mulheres que amamentam. Revista Latino-Americana de Enfermagem, Ribeirão Preto, v. 17, n. 3, p. 354-360, maio/jun. 2009. 
SOUZA, M. P. R.; TEIXEIRA, D. C. S.; SILVA, M. C. Y. G. Conselho tutelar: um novo instrumento social contra o fracasso escolar? Psicologia em Estudo, Maringá, v. 8, n. 2, p. 71-82, 2003.

SPOSITO, M. P. A instituição escolar e a violência. Caderno de Pesquisa: Revista de Estudos e Pesquisa em Educação, São Paulo, n. 104, p. 58-75, 1998.

SPOSITO, M. P. Um breve balanço da pesquisa sobre violência escolar no Brasil. Revista Educação e Pesquisa, São Paulo, v. 27, n. 1, p. 87-103, jan./jun. 2001.

STRATTON, P. Contemporary families as contexts for development. In: VALSINER, J.; CONNOLLY, K. (Org.). Handbook of developmental psychology. London: Sage, 2003. p. 333-357.

TROST, J. O processo de formação da família. In: GOMES-PEDRO, J.; PATRÍCIO, M. F. (Org.). Bebé XXI: criança e família na viragem do século. Lisboa: Fundação Calouste Gulbenkian, 1995. p. 55-67.

TURNER, L. H.; WEST, R. Providing a definition. In: TURNER, L. H.; WEST, R. (Org.). Perspectives on family communication. Mountain View, CA: Mayfield Publishing Company, 1998. p. 1-35.

UDE, W. Enfrentamento da violência sexual infanto-juvenil e construção de redes sociais produção de indicadores e possibilidades de intervenção. In: CUNHA, E. P.; SILVA, E. M.; GIOVANETTI, M. A. C. Enfrentamento à violência sexual infanto-juvenil: expansão do PAIR em Minas Gerais. Belo Horizonte: Editora UFMG, 2008. Parte I Fundamentos. p. 30-60.

VALE, D.; COSTA, M. A violência nas escolas. Lisboa: Instituto de Inovação Educacional, 1998.

WINNICOTT, D. W. Privação e delinquência. São Paulo: Martins Fontes, 1987.

WORLD HEALTH ORGANIZATION - WHO. Department of Injuries and Violence Prevention. Noncommunicable Diseases and Mental Health Cluster. The injury book: a graphical overview of the global burden of injuries. Geneva, 2002.

WORLD HEALTH ORGANIZATION - WHO. Handbook for the documentation of interpersonal violence prevention programs. Geneva, 2004.

ZALUAR, A.; LEAL, M. C. Violência extra e intramuros. Revista Brasileira de Ciências Sociais, São Paulo, v. 16, n. 45, p. 145-164, fev. 2001.

ZOTTIS, G. A. H. et al. Violência e desenvolvimento sustentável: o papel da universidade. Saúde e Sociedade, São Paulo, v. 17, n. 3, p. 33-41, 2008. 


\section{APÊNDICES}

\section{APÊNDICE A - Termo de autorização}

$\mathrm{Eu}$,

diretor

(a)

da , autorizo Michelly Rodrigues Esteves, aluna do

Programa de Pós-Graduação, nível Mestrado da Escola de Enfermagem de Ribeirão Preto/Universidade de São Paulo-EERP/USP, a realizar coleta de dados para a pesquisa intitulada "UM OLHAR SOBRE A REDE SOCIAL NO ENFRENTAMENTO DA VIOLÊNCIA ESCOLAR NAS INSTITUIÇÕES DE ENSINO MÉDIO DE ALFENASMG”, sob orientação da professora Dr ${ }^{a}$. Maria das Graças Bomfim de Carvalho. Tendo em vista que a pesquisa tem por objetivo identificar e analisar as redes sociais em torno das escolas de ensino médio pertencentes à rede estadual de Alfenas-MG para o enfrentamento dos casos de violência escolar e que o projeto segue as especificações da Resolução 196/96, que diz respeito à pesquisa em seres humanos.

Nome do (a) diretor (a) 


\section{APÊNDICE B - Termo de Consentimento Livre e Esclarecido}

Eu, Michelly Rodrigues Esteves, aluna do Programa de Pós-Graduação, nível Mestrado da Escola de Enfermagem de Ribeirão Preto/Universidade de São Paulo-EERP/USP, convido o Sr. (a) a participar da pesquisa intitulada "UM OLHAR SOBRE A REDE SOCIAL NO ENFRENTAMENTO DA VIOLÊNCIA ESCOLAR NAS INSTITUIÇÕES DE ENSINO MÉDIO DE ALFENAS-MG”, sob orientação da professora Dra . Maria das Graças Bomfim de Carvalho. Esta pesquisa tem por objetivo identificar e analisar as redes sociais em torno das escolas de ensino médio pertencentes à rede estadual de Alfenas-MG para o enfrentamento dos casos de violência escolar. Sua participação ocorrerá por meio do preenchimento do Mapa Mínimo da Rede Social Institucional (UDE, 2008) e de entrevista individual, os quais terão duração máxima de uma hora e meia, no período estimado de fevereiro a março de 2011.

O Sr. (a), ao participar da pesquisa deverá estar ciente de que:

1. Será preservado sigilo sobre sua identidade;

2. Haverá anonimato quanto ao seu nome;

3. Os resultados da pesquisa serão publicados;

4. Sua participação será voluntária;

5. A entrevista será gravada e marcada dependendo de sua disponibilidade;

6. A entrevista poderá ser interrompida a qualquer momento;

7. Poderá deixar de participar e retirar seu consentimento a qualquer momento;

8. A participação nesta pesquisa não traz complicações legais. Os procedimentos adotados obedecem aos Critérios da Ética em Pesquisa com Seres Humanos conforme Resolução nº. 196/96 do Conselho Nacional de Saúde. Nenhum dos procedimentos usados oferece riscos à sua dignidade;

9. Ao participar desta pesquisa o Sr. (a) não terá nenhum benefício direto. Entretanto, espera-se que este estudo traga informações relevantes quanto ao tema pesquisado;

10. Não haverá nenhum tipo de despesa para participar desta pesquisa, bem como nada será pago por sua participação;

11. Receberá uma cópia do Termo de Consentimento Livre e Esclarecido. 
Após estes esclarecimentos, solicitamos o seu consentimento de forma livre para participar desta pesquisa. Portanto preencha, por favor, os itens que se seguem:

\section{Consentimento Livre e Esclarecido}

Tendo em vista os itens apresentados, eu, de forma livre e esclarecida, manifesto meu consentimento em participar da pesquisa.

Nome do Participante da Pesquisa

Assinatura do Participante da Pesquisa

Assinatura da Pesquisadora

Assinatura da Orientadora

Para quaisquer esclarecimentos:

Escola de Enfermagem de Ribeirão Preto/Universidade de São Paulo-EERP/USP

Avenida dos Bandeirantes, 3.900-Monte Alegre, Ribeirão Preto-SP.

Pesquisadora: Michelly Rodrigues Esteves

Orientadora: Professora Dra ${ }^{\mathrm{a}}$. Maria das Graças Bomfim de Carvalho 


\section{ANEXOS}

\section{ANEXO A - Mapa Mínimo da Rede Social Institucional}

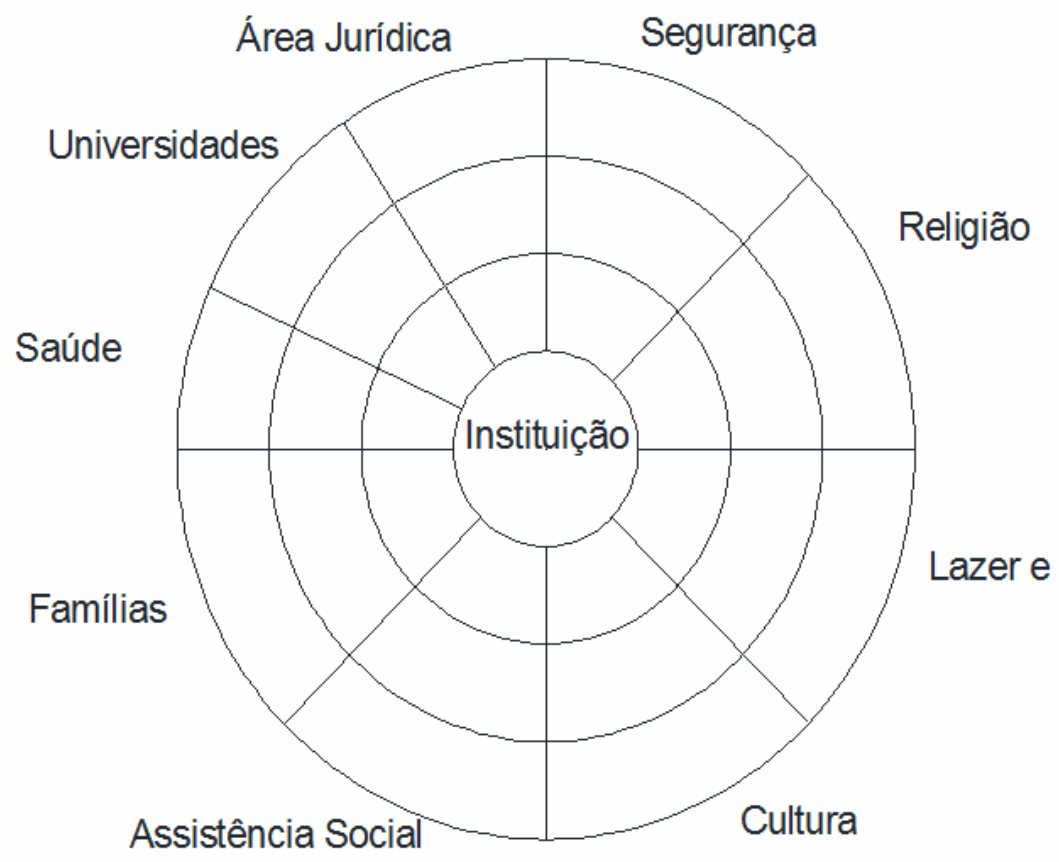

LEGENDA

RELAÇÕES SIGNIFICATIVAS:

RELAÇÕES FRAGILIZADAS:

RELAÇÕES ROMPIDAS OU INEXISTENTES: 